Julia Alvares de Aboim

Pulsão: um conceito limite entre Freud e Reich

Dissertação de Mestrado

Dissertação apresentada ao Programa de Pós-Graduação em Psicologia Clínica da Pontifícia Universidade Católica do Rio de Janeiro como parte dos requisitos para a obtenção do título de Mestre em Psicologia.

Orientador(a): Prof $\stackrel{\text { a }}{ }$ Monah Winograd 
Julia Alvares de Aboim

\section{Pulsão: um conceito limite entre Freud e Reich}

Dissertação apresentada como requisito parcial para obtenção do grau de Mestre pelo Programa de Pós-Graduação em Psicologia (Psicologia Clínica) do Departamento de Psicologia do Centro de Teologia e Ciências Humanas da PUC-Rio. Aprovada pela Comissão Examinadora abaixo assinada.

Profa. Monah Winograd

Orientadora

Departamento de Psicologia - PUC-Rio

Profa. Perla Klautau

Universidade Veiga de Almeida/RJ

Prof. Marcus Vinícius de Araujo Câmara

Departamento de Psicologia - UFRRJ

Profa. Denise Berruezo Portinari Coordenadora Setorial de Pós-Graduação

e Pesquisa do Centro de Teologia e Ciências Humanas - PUC-Rio

Rio de Janeiro, 24 de junho de 2015. 
Todos os direitos reservados. É proibida a reprodução total ou parcial do trabalho sem autorização da universidade, da autora e do orientador.

\section{Julia Alvares de Aboim}

Graduou-se em psicologia pela PUC-RJ (Pontifícia Universidade Católica do Rio de Janeiro) em 2006. Cursou especialização em Análise Bioenergética pela SABERJ (Sociedade Brasileira de Análise Bioenergética do Rio de Janeiro), entre os anos de 2003 e 2008. Participou em diversos cursos na área de terapias corporais de base reichiana e atua como psicóloga clínica em clínica particular.

Ficha Catalográfica

Aboim, Julia Alvares de

Pulsão: um conceito limite entre Freud e Reich / Julia Alvares de Aboim ; orientadora: Monah Winograd. - 2015.

127 f. : il. ; $30 \mathrm{~cm}$

Dissertação (mestrado)-Pontifícia Universidade Católica do Rio de Janeiro, Departamento de Psicologia, 2015. Inclui bibliografia.

1. Psicologia - Teses. 2. Pulsão sexual. 3. Pulsão de morte. 4. Masoquismo. 5. Energia orgástica. 6. Estase libidinal. I. Pischetola, Magda. II. Pontifícia Universidade Católica do Rio de Janeiro. Departamento de Psicologia. III. Título. 
A Gustavo, meu marido, pois sem o seu apoio, amor e cuidado comigo, esse trabalho não teria chegado ao fim. 


\section{Agradecimentos}

A Monah Winograd, minha orientadora, pelo seu apoio carinhoso e principalmente por acreditar em mim e me incentivar no percurso acadêmico.

A Eduardo Rozenthal, cuja escuta e acolhimento tem me ajudado a encontrar o norte.

A Ana Luz Francés, pela sabedoria e conversas calorosas sobre Reich. 


\section{Resumo}

Aboim, Julia Alvares de; Winograd, Monah (Orientadora). Pulsão: um conceito limite entre Freud e Reich. Rio de Janeiro. 2015, 127 p. Dissertação de Mestrado - Departamento de Psicologia Clínica, Pontifícia Universidade Católica do Rio de Janeiro.

Nesta dissertação o conceito freudiano de pulsão é articulado com a teoria econômico-sexual de Reich. Sob a ótica deste autor a pulsão ganha uma nova leitura que permite rediscutir este conceito sob um viés orgânico-energético. Assim, Reich desenvolve a teoria da libido de Freud, buscando demonstrar que a libido frustrada em sua finalidade (estase libidinal) constitui a fonte de energia que alimenta as neuroses. Em relação à pulsão de morte, Reich argumenta contra a ideia de haver no ser vivo um impulso à morte e, por conseguinte, contra a noção de um masoquismo erógeno, uma autodestruição primária. Dessa forma, ao desconsiderar a primazia da pulsão de morte, o dualismo pulsional, na visão reichiana, também não se sustentaria.

\section{Palavras-chave}

Pulsão sexual; pulsão de morte; masoquismo; energia orgástica; estase libidinal 


\section{Abstract}

Aboim, Julia Alvares de; Winograd, Monah (Advisor). Drive: a border concept between Freud and Reich. Rio de Janeiro. 2015, 127 p. MSc. Dissertation - Departamento de Psicologia Clínica, Pontifícia Universidade Católica do Rio de Janeiro.

In this thesis the Freudian concept of drive is linked to Reich's sex-economy theory. From the perspective of this author the concept of drive (Trieb) acquires a new interpretation that allows to revisit this concept in an organic-energy view. Reich developed Freud's libido theory, seeking to demonstrate that a frustrated libido (libidinal stasis) is the source of energy supplying the neurosis. Regarding the death drive, Reich argues against the idea of a natural impetus to death and therefore against the notion of an erogenous masochism, a primary selfdestruction. Thus, the Reichian vision disregards the primacy of the death drive and rejects the instinctual dualism.

\section{Keywords}

Sexual drive; death drive; masochism; sexual energy; libidinal stasis 


\section{Sumário}

$\begin{array}{ll}\text { Introdução } & 9\end{array}$

1. Pulsão: do termo ao conceito 14

1.1 - Reich e a Psicanálise 14

1.2 - Os significados de Trieb 23

1.3 - As traduções de Trieb na obra de Freud 29

1.4 - As traduções de Trieb na obra de Reich 37

2. Primeira teoria pulsional: pulsão sexual 42

2.1 - Formando o conceito de pulsão (Trieb) 42

2.2 - A primeira dualidade pulsional 49

2.3 - Pulsões e a formação do psiquismo 54

2.4 - Sexualidade e Genitalidade $\quad 57$

2.5 - Reich e a primeira teoria pulsional 62

2.6 - A teoria da libido sob a perspectiva de Reich 66

3. Além do Princípio do Prazer 76

3.1 - Metáforas biológicas e narcisismo 76

3.2 - Compulsão à repetição $\quad 80$

3.3 - O caráter conservador das pulsões $\quad 84$

3.4 - Reich e a pulsão de morte 94

3.5 - O Caráter pulsional 96

3.6 - O masoquismo em Freud e Reich 106

3.7- Agressividade e o conflito entre necessidade e mundo externo 111

$\begin{array}{ll}\text { Considerações finais } & 118\end{array}$

$\begin{array}{ll}\text { Referências bibliográficas } & 123\end{array}$ 


\section{Introdução}

Este trabalho propõe uma sistematização da produção de Reich, relativa à matriz psicanalítica de seu pensamento, ressaltando a importância de suas observações e desdobramentos acerca do fundamento energético-quantitativo (ponto de vista econômico), formulado por Freud. O fundamento energético será abordado aqui através do conceito de pulsão (Trieb), que constituirá o campo onde se dará a articulação entre as teses de Freud e Reich.

Tendo como solo conceitual a primeira e a segunda teoria pulsional freudiana, com ênfase nos textos centrais 'Pulsão e suas vicissitudes' (1915) e 'Além do princípio do prazer' (1920), serão analisadas as teses reichianas que dialogam com os dois principais conceitos de ambas as teorias: pulsão sexual e pulsão de morte.

Pretende-se um recorte de parte da obra reichiana que dialoga com a obra de Freud, guardando em vista os seguintes aspectos: 1) as contribuições ofertadas por Reich aos problemas econômicos da teoria freudiana, com especial atenção à ‘teoria do orgasmo'; e 2) as principais críticas feitas pelo autor à pulsão de morte e consequentemente ao dualismo pulsional.

Para cumprir o objetivo deste trabalho serão utilizados, majoritariamente, os textos freudianos de 1915 e 1920 citados acima, cujas teses serviram de norteadores para a articulação com as proposições de Reich. Além disso, como parte da bibliografia essencial para esta pesquisa, preponderará nas discussões os textos reichianos da década de 20 - 'Conceitos de pulsão e libido de Forel a Jung' (1922), ‘O caráter impulsivo' (1925), ‘A função do orgasmo: psicopatologia e sexologia da vida sexual' (1927) - e o artigo sobre o caráter masoquista de 1932.

Outros textos dos dois autores também serão utilizados para complementar e confrontar os artigos principais, no entanto, é importante ressaltar que, a fim de manter a fidelidade do debate e deixar o campo o mais circunscrito possível, serão priorizados os textos reichianos produzidos ao longo do período psicanalítico, além do artigo de 1942 'A função do orgasmo: problemas econômico-sexuais da energia biológica', onde Reich retoma e amplia as teses desenvolvidas no seu artigo homônimo de 1927. 
A dissertação então contará com três capítulos. O primeiro, dedicado ao termo Trieb e ao conceito de pulsão, também introduzirá a relação entre os dois autores. Nesta introdução, exporemos as opiniões de Reich sobre a figura de Freud e a psicanálise, como foi seu ingresso na sociedade psicanalista de Viena, seu envolvimento com o partido comunista austríaco, suas ideias controversas, a relação com os demais psicanalistas, dentre outras questões. Reich também revelará sua percepção sobre o professor Sigmund Freud e como foi a receptividade deste ao receber a sua primeira obra importante, 'A função do orgasmo' (1927). Os relatos expostos nesta parte introdutória foram retirados, em sua maioria, de uma entrevista fornecida por Reich (1952) aos Arquivos de Sigmund Freud e da sua autobiografia científica de 1942, contida na 'Função do orgasmo' (1942).

Em seguida contaremos com o auxílio do psicanalista e estudioso dos termos alemães que integram o texto freudiano, Luiz Hanns, que apresentará o termo Trieb com todos os seus nuances. Hanns (1996) retrata o termo alemão no seu uso coloquial, explicando seus significados, introduzindo a ideia de um 'arco' onde a definição de Trieb "parte do absoluto e grandioso, passa pela espécie e chega ao indivíduo específico" (Hanns, 1999, p. 32). Esta ideia é valiosa, pois, além de facilitar o entendimento da razão pela qual Freud escolheu este termo para compor o quadro de conceitos da psicanálise, ajuda a resolver as questões em torno de sua tradução.

As traduções do conceito Trieb também serão abordadas nesta primeira parte. Compreender a polêmica que circunda as traduções de Trieb contribui ao entendimento da plasticidade deste conceito. Não é raro, por exemplo, ouvir críticas sobre a tradução por 'instinto' sob diversas alegações, dentre elas o risco de se biologizar a psicanálise. No entanto, como será visto, esta opinião não é unânime entre os estudiosos da psicanálise e nem entre os tradutores. Contudo a tradução mais usada atualmente é, sem dúvida, 'pulsão'.

Não é apenas nas obras de Freud que as traduções de Trieb causam polêmica, como se verá, os tradutores de Reich também passaram por questões semelhantes. No entanto, neste caso, parece não haver uma grande divergência quanto às intenções de Reich ao fazer uso do conceito Trieb. Sob uma perspectiva científico-natural, os tradutores deste autor acreditam que 'impulso' seria o termo 
que melhor se encaixaria na versão de Trieb para o português. Todavia, considerando que este conceito é uma herança dos tempos em que Reich fora filiado à instituição psicanalítica, para não haver confusão, na opinião de muitos tradutores e teóricos reichianos, o termo pulsão pode ser usado sem prejudicar seu sentido.

Partindo do geral para o específico - do conceito psicanalítico de pulsão para a primeira teoria pulsional -, o segundo capítulo se destinará à primeira teoria das pulsões com especial ênfase à sexualidade (pulsão sexual). Este capítulo, assim como o terceiro, será dividido em duas partes: a primeira, dedicada a Freud, abordará suas teses sobre a pulsão sexual e o seu par oposto, a pulsão de autoconservação (ou pulsão do ego); e a segunda parte, será dedicada à articulação com a teoria reichiana.

Assim, as teorias de Freud servirão como fundamento de onde procederá a teoria reichiana, pois, como estamos abordando o período psicanalítico de Reich, é importante deixar claro as suas referências. Partindo das ideias de sexualidade e libido (pulsão sexual na forma de energia psíquica), Reich vai desenvolver a teoria do orgasmo que é, em ultima instância, a sua resposta à técnica usada para tratar os neuróticos nos consultórios de psicanálise.

Simplificadamente, para a teoria psicanalítica da época (1915), a sexualidade (considerada no seu sentido mais amplo como pulsão sexual) entra em atrito com o ego que, para proteger a integridade do indivíduo, desenvolve uma defesa (recalque) a fim de manter os impulsos sexuais afastados da consciência e, com isso, proteger o sujeito de um possível constrangimento. Dessa forma, considerando a associação livre como método, um analista ajudará o neurótico a trazer os conteúdos recalcados inconscientes à consciência. Quando o sintoma consegue finalmente ser expresso verbalmente, isto é, quando ele atinge a consciência, é sinal de que a 'cura' está a caminho.

Reich, porém, observou ao longo do tempo em que passou atendendo pacientes ambulatoriais, que em muitos casos o sintoma que aparentava ter desaparecido, reaparecia. Como se verá, o autor atribui isso ao fato de o paciente não ter sido tratado 'genitalmente', na sua capacidade orgástica. Ou seja, para o autor não bastava tratar dos conteúdos psíquicos se a fonte de energia que alimentava as neuroses - estase libidinal - não era tratada. Assim, em 1927, Reich finalmente publica um trabalho que vinha desenvolvendo há algum tempo, a 
'Função do Orgasmo', com o intuito de expor a Freud as teses que acreditava complementares à teoria e à técnica psicanalítica.

Reich então se aprofunda cada vez mais no campo de conhecimento que vinha elaborando, tendo em vista um aspecto mais orgânico e energético da pulsão sexual. Este novo olhar sobre a pulsão sexual influenciou também a maneira como o autor vai encarar a segunda teoria pulsional.

Assim, a segunda teoria pulsional será abordada no terceiro e último capítulo desta dissertação, que também será dividido em duas partes, sendo que a primeira parte versará sobre o artigo freudiano de 1920, 'Além do princípio do prazer'. Este artigo foi priorizado porque é um texto de referência que introduz e contém o germe dos elementos que viriam a ser abordados em artigos posteriores pelo próprio Freud.

É, pois, em 1920 que Freud introduz o conceito de pulsão de morte (Thânatos), considerando-a uma pulsão silenciosa - especialmente se comparada a Eros, seu par oposto -, que objetiva retornar ao estado inorgânico da matéria, podendo ser observada clinicamente através do fenômeno da 'compulsão à repetição' e nos comportamentos autodestrutivos e sádicos (quando voltada ao mundo externo).

Além disso, como será mais bem descrito por Freud em 1923, em 'Dois verbetes de enciclopédia', a pulsão de morte se apresentará fusionada a Eros, sendo percebida mais facilmente a partir de sua desfusão. Em 1924, em 'O problema econômico do masoquismo', Freud irá trabalhar com a ideia de uma pulsão de morte próxima ao conceito de masoquismo erógeno (primário), chegando, inclusive, a equipara-los. A presente pesquisa abordará então o conceito de pulsão de morte até este período (1924).

Portanto, não será desenvolvida neste trabalho a ideia de pulsão de morte exposta no 'Esboço de psicanálise' (1938) que a considerava como disjuntiva: “O objetivo da primeira [Eros] dessas pulsões básicas é estabelecer unidades cada vez maiores e assim preservá-las - em resumo, unir; o objetivo da segunda [Thânatos], pelo contrário, é desfazer conexões e, assim destruir coisas" (Freud, 1938, p. 173).

Assim, também não será trabalhada aqui a pulsão de morte como pura destrutividade (autônoma) - desvinculada da sexualidade, não erótica - como 
aparece em 1930 no 'Mal estar da civilização'. Esta escolha foi deliberada, uma vez que se priorizou enfatizar a face da pulsão de morte com que Reich dialoga.

O objetivo é conhecer de onde Reich partiu e quais as teorias e conceitos freudianos que este autor irá considerar e articular para propor as suas ideias. Em se tratando da segunda teoria das pulsões, Reich desenvolveu toda uma justificativa que considerava Eros, mas desprezava Thânatos.

Com especial atenção à pulsão de morte, Reich vai argumentar, principalmente contra a ideia de haver no ser vivo um impulso à morte e, por conseguinte, contra a noção de um masoquismo erógeno, uma autodestruição primária. Dessa forma, ao desconsiderar a pulsão de morte, o dualismo pulsional também não se sustentaria. Com isso, o conflito que subjaz às neuroses não poderia ser um conflito entre duas pulsões primordiais - Eros e Thânatos -, mas um conflito entre Eros (ou, segundo o autor, as 'necessidades'), e algo que se oporia a Eros. Reich vai propor então que seria o mundo externo, repressor da sexualidade e das expressões espontâneas, que irá se contrapor a satisfação sexual (plena descarga orgástica). 


\section{Pulsão: do Termo ao Conceito}

\section{1}

\section{Reich e a Psicanálise}

Wilhelm Reich, um dos inúmeros discípulos de Sigmund Freud, manteve-se filiado à Associação Psicanalítica de Viena (APV) por quatorze anos. Seu encontro com o pai da psicanálise ocorreu em 1919 e no ano seguinte, aos 23 anos de idade, já participava das reuniões da APV como membro efetivo. Em menos de um ano, Reich achava-se atuando na Policlínica Psicanalítica de Viena, da qual mais tarde (1928) seria eleito vice-diretor.

$\mathrm{Na}$ Policlínica, além de atender aos pacientes, contribuía com ideias, pesquisava novas técnicas e formulava teorias. Uma de suas ideias foi a criação do Seminário Técnico, para o qual viria a ser convidado a exercer a função de coordenador em 1924. Segundo Reich (1952), o Seminário Técnico "foi realmente o berço da técnica psicanalítica tal como é praticada hoje. Assim, Freud viu progressos, progressos clínicos. Viu progressos técnicos, também. Foi uma grande alegria para ele que a vida tivesse entrado naquele corpo morto" (Reich, 1952, p.51).

Como a Clínica era destinada a pacientes sem condições de pagar tratamento particular, a demanda tornou-se enorme. Para Reich (1952), isso constituía indicativo de que a neurose era uma 'doença de massa', uma 'epidemia' que precisava de uma terapia com aplicação generalizada, indo além dos limites do consultório. "Isso afastou-me da associação psicanalítica - não da psicanálise, mas da associação, dos meus colegas. Conduziu-me para o exterior, para a sociologia” (Reich, 1952, p. 52).

Sociologia e política, a propósito, formavam campos que se mesclaram por algum tempo na visão de Reich, o que o levou a ingressar no partido comunista austríaco em 1927. Na sua concepção, o partido comunista poderia ser de grande ajuda, devotando sua estrutura a serviço das ideias de prevenção da neurose para um grande número de pessoas. Mas, não foi só a estrutura do partido político que 
o atraiu, na verdade, esta foi uma consequência do seu entusiasmo com as obras de Marx e Engels.

$\mathrm{Na}$ época Reich acreditava ter encontrado na psicanálise a principal teoria que inspirava sua visão sobre a sexualidade humana, no entanto, sentia a necessidade de outra formulação que pudesse ampliar sua percepção aos mecanismos sociais, um método que o apoiaria na forma de conduzir e praticar a profilaxia das neuroses. E encontrou nas ideias de Marx a materialização do seu anseio. Dessa forma, no período entre 1927 e 1930, Reich realizou inúmeros trabalhos sociais com o apoio do partido comunista. Em 1928 fundou a 'Sociedade Socialista de Informação e Investigação Sexuais' e em 1929 criou numerosos 'Centros de Higiene Sexual' em Viena (Reich, 1927, pp. 12, 13). Nesta época também produziu a obra 'Materialismo Dialético e Psicanálise' com o intuito de aproximar a teoria psicanalítica com as ideias marxistas.

Assim, supomos que um dos objetivos de Reich, ao aproximar a psicanálise da política, seria o de realizar um desejo expresso por Freud em 1898:

Mas, acima de tudo, é necessário criar um espaço na opinião pública para a discussão dos problemas da vida sexual. Tem que ser possível falar sobre essas coisas sem que se seja estigmatizado como um arruaceiro ou uma pessoa que tira proveito dos mais baixos instintos. E também aqui há trabalho suficiente para se fazer nos próximos cem anos - nos quais a nossa civilização terá que aprender a conviver com as reivindicações de nossa sexualidade (Freud, 1898, p. 264).

Acontece que, anos mais tarde, o próprio Reich (1952) viria a admitir a diferença entre o 'social' e a 'política', observando que, de acordo com essa diferença, Freud seria 'apolítico'. No entanto, esta posição 'apolítica' do metapsicólogo só veio a se sedimentar em Reich anos depois, tendo este confessado, ao ser indagado a respeito das posições políticas de Freud, o seguinte:

Politicamente? Ele sempre disse, 'Sou um cientista. Nada tenho a ver com política'. E uma vez que a política estava intimamente ligada à sociologia, eu disse, 'esse é um ponto de vista impossível'. Não se pode ser apolítico numa situação como a que o mundo então atravessava. Sabe qual era, os anos de depressão. Mas ele estava certo no que respeitava a política, porque a política é irracional. Estava errado no que respeitava à ciência social. Mas a culpa não era dele, uma vez que a distinção não se fazia. Tivemos que aprender a fazê-la à nossa própria custa. Tivemos que fazer a distinção entre o social e o político. Ele não tinha - sim, tinha um ponto de vista político. Um ponto de vista judeu. (Reich, 1952, pp. 84, 85).

Ainda em 1927, Reich entendia existir um denominador comum entre as ideias de Marx e Freud, e é este denominador - a saber, o princípio energético que interessa ao propósito do presente trabalho. Em linhas gerais, foi este 
princípio que aproximou Reich da psicanálise e posteriormente do marxismo (Bedani, 2007). O 'Freudo-Marxismo' (tese de Reich) em si extravasa o escopo do presente trabalho e por tal razão não será aqui abordado, embora se reconheça nele um dos temas importantes da trajetória do autor, tendo inclusive provocado segundo o relato de estudiosos - o motivo de sua posterior expulsão da Associação Psicanalítica.

Realizadas essas considerações introdutórias, faz-se necessária uma digressão sobre esse princípio energético, com o intuito de preparar o posterior ingresso nas teses de Reich, compreender seu pensamento e a importância do conceito energético psicanalítico de pulsão na teoria reichiana. Em primeiro lugar, o conceito de energia reichiano nada tem de esotérico; ao contrário, é bem físico, observável e investigável. Em segundo lugar, a questão energética e a sexualidade, na concepção de Reich, andam juntas e muitas vezes até se confundem.

Desde 1920 Reich já pesquisava sobre os processos energéticos vitais (Bedani, 2007) que culminaram na bioenergia e, mais tarde na descoberta da energia orgone. Esta pesquisa e suas descobertas Reich deve muito a Freud:

O meu trabalho prossegue com a expressão emocional bioenergética. Porque levanto eu esta questão? Por uma simples razão: Se Freud não tivesse existido e feito o seu trabalho, não teria sido possível penetrar para além da linguagem verbal, para além do inconsciente até a expressão bioenergética, até a forma bioenergética de expressão do organismo (Reich, 1952, p. 39).

Também, a respeito da importância do fator energético na concepção reichiana, Paulo Albertini (1994) concorda com a biógrafa de Reich, Ilse Ollendorff De Reich, para quem esse é o fio condutor central - 'fio vermelho' presente ao longo da obra do autor. Segundo De Reich (1969) "Não havia nada surpreendente no fato de que Reich cruzara as linhas de distintas disciplinas acadêmicas porque sua ideia principal, desde o começo, foi a ideia de energia..." (De Reich apud Albertini, 1994, p. 37).

Para ilustrar tal afirmação, observamos que o primeiro texto científico publicado por Reich, em 1922, referia-se aos 'Conceitos de Pulsão e Libido de Forel a Jung' que, justamente, era dedicado ao estudo dos conceitos de energia. Ao final deste trabalho Reich também aponta para uma análise mais aprofundada da base orgânica da libido (Albertini, 1994). 
Assumindo que a Libido é a energia das pulsões sexuais, - ou seja, para Freud (1895), é o conceito que representa a energia sexual atuante no psíquico Reich (1922) enfatiza dois aspectos deste conceito: a sua face orgânica e a sua face quantificável. "Pode-se observar daí que tanto a preocupação quantitativa quanto a busca da base orgânica da libido caminham na direção de uma energia sexual como algo real e não apenas como um constructo teórico necessário para a elaboração da teoria" (Albertini, 1994, p. 38).

Com isso, podemos supor que a principal ligação entre os pensamentos de Reich e Freud encontra-se no campo da quantidade de energia libidinal ou, em outras palavras, no 'ponto de vista econômico'. Para abordar o 'ponto de vista econômico', é importante observar que este é um dos três pontos de vista dinâmico, tópico e econômico - que definem a metapsicologia freudiana, sendo entendido como aquele que “... se esforça por levar até as ultimas consequências as vicissitudes de quantidades de excitação e chegar pelo menos a uma estimativa relativa de sua magnitude" (Freud, 1915, p. 186).

O 'econômico' aqui se refere a uma economia psíquica que consiste em considerar a mobilidade, as variações de intensidades e as oposições de investimentos. Segundo Laplanche e Pontalis (1982), "ao longo de toda a obra de Freud estão presentes considerações econômicas; para ele, não seria possível a descrição completa de um processo psíquico sem a apreciação da economia dos investimentos" (Laplanche e Pontalis, 1982, p. 121).

Além da face econômica (quantificável) da libido, a sua face orgânica é também de extremo valor a Reich - neste caso, o 'orgânico' é representado pelo conceito de 'genitalidade' que será esmiuçado mais adiante, no próximo capítulo. Esta 'face orgânica' nos faz lembrar que Reich chegou à psicanálise - juntamente com a questão energética que o motivava -, através da sexologia. Não à toa que tenha achado a teoria das 'neuroses atuais' - a qual chamou de neuroses estásicas sexuais -, muito mais interessante e científica do que a interpretação do significado dos sintomas nas 'psiconeuroses' (Reich, 1942).

Freud (1898) denominava de 'neurose atual' (neurastenia e neurose de angústia) as enfermidades causadas pelas perturbações presentes da vida sexual e que não tinham uma etiologia psíquica. Segundo Reich (1942), Freud achava que as neuroses atuais eram manifestações diretas de uma sexualidade reprimida, e “presumia que o corpo continha 'substâncias químicas' de 'natureza sexual' que, 
se não eram adequadamente 'metabolizadas', produziam palpitações nervosas, irregularidade cardíaca, crises agudas de angústia, suor e outros sintomas da vida vegetativa" (Reich, 1942, p. 83).

Por outro lado Freud (1898) nos lembra que “... em todo caso de neurose há uma etiologia sexual; mas na neurastenia é uma etiologia de tipo contemporâneo, enquanto nas psiconeuroses os fatores são de natureza infantil. (...) em geral as duas neuroses aparecem juntas" (Freud, 1898, p. 255 - grifo nosso). Seguindo este raciocínio, Reich (1942) afirma não ter dúvidas de que "as psiconeuroses tinham um cerne neurótico atual (estase) e que as neuroses estásicas tinham uma superestrutura psiconeurótica" (Reich, 1942, p. 85). Afinal de onde mais poderia ser retirada a energia que sustentaria uma psiconeurose, se não do seu 'cerne neurótico atual' da excitação sexual reprimida?

Esta questão colocou Reich diante de uma tarefa: ao longo de seu trabalho clínico, muito atento à etiologia sexual das neuroses, cuidava para não deixar escapar qualquer informação impregnada de elemento sexual, assim como buscava denunciar os efeitos da repressão no comportamento sexual de seus pacientes. Desta forma, constatou que na totalidade dos casos, as pessoas sofriam por não conseguirem se expressar sexualmente de forma 'sadia'.

Esta constatação lhe apontou duas maneiras de proceder frente à neurose: a primeira, como visto anteriormente, seria voltada para fora dos consultórios, atuaria na profilaxia, com centros de higiene sexual destinados a atender e fornecer informações sobre sexualidade para a população carente de Viena. A outra maneira de lidar com a neurose seria através de uma reformulação da técnica analítica usada dentro dos consultórios, utilizando uma técnica sugerida por ele análise do caráter. A análise do caráter seria embasada tanto pela teoria psicanalítica quanto pela 'teoria do orgasmo', formulada por Reich.

A teoria do orgasmo foi fruto do aprofundamento da teoria freudiana da libido, com um viés mais orgânico. Este aprofundamento se deve à visão de Reich sobre a psicanálise ser uma ciência natural, "mesmo que tentem provar o contrário", e seu papel é defender esta causa: "sabíamos entretanto que, pela primeira vez na história da psicologia, estávamos praticando ciência natural"

\footnotetext{
${ }^{1} \mathrm{~A}$ teoria do orgasmo consiste basicamente em restabelecer o fluxo de energia no organismo, ou seja, se a neurose estásica (estase = energia represada) é fruto da descarga incompleta da bioenergia, então é necessário restabelecer o fluxo de energia através da completa descarga orgástica, e isto só poderia ser alcançado através do orgasmo genital.
} 
(Reich, 1942, p. 86). Com isso, Reich (1927) se empenhou em demonstrar a atuação da libido no organismo, e estabeleceu o orgasmo genital como seu correspondente.

Sua teoria do orgasmo não foi bem aceita por Freud. Em 1926, Reich foi ao apartamento do psicanalista entregar-lhe pessoalmente o manuscrito da primeira versão de Die Funktion des Orgasmus e dedicou-lhe o livro: "A meu mestre, o professor Sigmund Freud, como prova de profundo respeito" (Reich, 1927, p. 23). No entanto, conforme relata na sua autobiografia científica em 1942, a reação de Freud revelou-se um tanto negativa: "Pareceu meio aborrecido ao ler o título. Olhou o manuscrito, hesitou por um momento e disse como se estivesse agitado: 'tão grosso?' Não me senti muito à vontade. A sua reação não fora racional. Era muito polido e normalmente não teria feito uma observação tão cortante" (Reich, 1942, p. 147).

Assim, Reich insistiu em provar tanto para Freud quanto aos demais psicanalistas que estava, de fato, seguindo os caminhos traçados pelo próprio Freud. No entanto, a animosidade com que fora recebido em 1925 no seminário técnico, devido ao seu trabalho sobre a genitalidade, mostrava que este caminho, enxergado por Reich como continuidade e aprofundamento de certas teses freudianas, não era aceito pelos seus colegas.

Inicialmente, não entendi porque surgiu aquela animosidade. Eu era tido em muita consideração, de 1920 até cerca de 1925 ou 1926. E depois senti aquela animosidade. Eu tinha tocado em algo doloroso - genitalidade. Eles não gostaram. Eles não queriam. Hitschmann foi o único que disse, 'você pôs o dedo na ferida (Reich, 1952, p. 29).

Reich (1952) atribuiu a hostilidade com que Freud e os demais psicanalistas tratavam suas descobertas à "peste emocional'2. Considerava que a psicanálise vinha se afastando do seu propósito inicial devido à imensa dificuldade que encontrava em sugerir ideias sobre sexualidade a uma cultura moralista e patologizante. E este era o ponto de maior conflito entre os dois autores; Reich queria uma revolução dos costumes, uma 'revolução sexual'. Desejava levar a

\footnotetext{
${ }^{2}$ A peste emocional é uma enfermidade causada por uma disfunção básica do sistema neurovegetativo, que compromete tanto o físico quanto o emocional daqueles acometidos pela doença. Esta se manifesta intimamente ligada ao 'caráter neurótico', apesar de nem todo neurótico ser 'infectado' pela peste. Segundo José Henrique Volpi (2003), uma pessoa acometida pela peste emocional, não consegue se promover pelo próprio esforço e busca se promover por meio da destruição do outro.
} 
teoria da libido para fora dos consultórios e transformar a educação, a formação das crianças e o ambiente familiar, mas encontrava resistência em Freud.

Freud concordava comigo no respeitante a princípios. Mas quando se chegou a casos concretos, tais como atacar a atitude compulsiva da família, a organização da família, ele insurgiu-se contra isso e insurgiu-se contra mim. Isto é muito importante. Foi aqui que todo o conflito começou. (...) Evidentemente, em princípio ele concordava com a importância da saúde sexual. Mas ele não aceitava o que a saúde sexual implicava, o ataque a certas instituições que se lhe opunham (Reich, 1952, p. 86).

Alguns autores, como Claudio Melo Wagner (1996), defendem que a ruptura entre Freud e Reich se deu, não no âmbito da produção científica de Reich, uma vez que a perspectiva reichiana está vinculada, em sua essência, ao ponto de vista econômico freudiano, mas no âmbito político. Isto é, o insistente propósito de levar a campo seu trabalho de higiene sexual, valendo-se da máquina política do partido comunista era, segundo Wagner (1996), a principal razão para o desligamento de Reich da psicanálise. Ou seja, suas ideias revolucionárias colocavam em risco a instituição psicanalítica, dentro do contexto histórico pelo qual atravessava a Europa no início dos anos 30.

Reich (1952) em entrevista concedida aos Arquivos de Sigmund Freud, conclui que sua expulsão da Associação Psicanalítica se deu basicamente por dois motivos: o primeiro, em razão das intrigas de que foi alvo por parte de seus colegas junto a Freud - devido à 'peste emocional'. Em outras palavras, o fato de o autor levar tão a sério a influência da sexualidade como causa principal das neuroses, de expandir sua problemática ao âmbito genital e de se dedicar a desenvolver este aspecto - o da genitalidade - da teoria psicanalítica, "põe o dedo na ferida”. Falar de 'orgasmo genital', segundo Reich (1952), incomoda principalmente aqueles que possuem uma estrutura de caráter neurótica e que não conseguem vivenciar sua sexualidade de forma satisfatória: "Muitos psicanalistas tinham distúrbios genitais e essa a razão do seu ódio. É isso" (Reich, 1952, p. 30).

O outro motivo apontado por Reich (1942) foi a divergência em relação ao modo de ver e interpretar a teoria psicanalítica, haja vista o rumo que a psicanálise havia tomado especialmente após 1920. Estas discordâncias se explicitavam principalmente no tocante a sua leitura sobre a teoria da libido. Dito de outra forma, embora Reich acreditava que estava sendo fiel aos 'verdadeiros' propósitos da psicanálise, a instituição o considerava obsoleto. A psicanálise pós 1920 integrava em seu corpo teórico a pulsão de morte e a segunda tópica - em 1923 
Freud publica 'o ego e o id' - e com isso o conceito de sexualidade se ampliava ainda mais. Reich não enxergava as coisas desta maneira pois entendia que a psicanálise estava se 'dessexualizando' e por isso se fazia mister a defesa da 'psicanálise profunda', ou seja, da psicanálise voltada para seus primórdios, quando a intenção de se provar como ciência natural ainda se colocava no horizonte. A ‘teoria do orgasmo' provaria a face biológica, orgânica da libido e o aprofundamento do ponto de vista econômico a tornaria quantificável.

Com a palavra, Reich:

Em 1920, Freud havia publicado 'Beyond the Pleasure Principle', no qual, inicialmente como uma hipótese, o instinto de morte estava colocado no mesmo pé de igualdade que o instinto sexual, embora o autor lhe atribuísse uma força instintiva mais profunda. (...) Era uma situação muito confusa. Em vez de sexualidade, os analistas começaram a falar de Eros. (...) A sexualidade tornou-se algo indistinto; o conceito de 'libido' foi despido de todos os traços de conteúdo sexual e transformou-se em uma figura de retórica. (...) a atmosfera estava-se tornando refinada! (...) os analistas ainda mencionavam a sexualidade, mas tinham algo diferente na cabeça. Ao mesmo tempo, haviam conservado um resquício do velho orgulho pioneiro. Mas tinham desenvolvido uma consciência má e usurparam os meus novos achados, declarando-os componentes tradicionais da psicanálise, com a intenção de destruí-los. (...) Foi em 1934 que o percebi claramente. Era tarde demais. Até então, dominando a minha convicção íntima da minha própria causa, eu havia lutado dentro da estrutura da Associação Psicanalítica Internacional, oficialmente e por mim mesmo, em nome da psicanálise (Reich, 1942, pp. 112, 113).

Contudo, ao responder sobre a postura de Freud diante das mudanças que a psicanálise atravessava, Reich (1952) afirmava que o psicanalista fora capturado pela admiração de seus discípulos e não tinha tido a coragem de trilhar o 'caminho da solidão’ (Reich, 1952) necessário para preservar seus pensamentos originais, deixando-se influenciar e com isso alterando os rumos da psicanálise: "Freud era uma mistura curiosa de um espírito muito aberto e de um senhor professor de 1860. Mesmo assim, apesar do seu conservadorismo, era bastante aberto e evoluído. Não acho que ele, pessoalmente, tenha traído a sua causa, mas deixou-se apanhar. Deixou-se apanhar por muitos estudantes que queriam dele toda a espécie de coisas e lhe ofereciam admiração em troca" (Reich, 1952, p.44).

Reich (1952) considerava que a originalidade de Freud residia na descoberta do princípio de funcionamento da energia no aparelho psíquico: "Foi isso que o distinguiu de todos os outros psicólogos" (Reich, 1952, p. 29). Assim, a teoria do inconsciente - considerada unanimemente, entre psicanalistas e leigos em psicanálise, como a grande descoberta de Freud - foi remanejada por Reich 
(1952) a uma condição de consequência "do princípio científico natural - a 'teoria da libido" introduzido por Freud (Reich, 1952, p. 29). Ou seja, é na 'teoria da libido', que Reich avista a causa freudiana.

Acontece que em 1920 ao apresentar o conceito de pulsão de morte, Freud a coloca como a pulsão mais elementar. Nessa linha, o que nos moveria não seria mais a pulsão sexual - e consequentemente sua energia libidinal -, mas o impulso à morte: "o objetivo de toda a vida é a morte" (Freud, 1920, p. 49).

Essa era a questão! Reich desenvolve toda a sua 'teoria do orgasmo' visando comprovar a existência real da libido - energia orgástica -, considerandoa não só um fenômeno psíquico, mas um fenômeno, sobretudo, orgânicoenergético e, posteriormente, primário na constituição do ser vivo. Com o advento da pulsão de morte, a psicanálise escolhe um caminho que se torna inviável de ser trilhado por Reich, pois ele não conseguia explicar tal conceito pela via de suas observações clínicas e muito menos relacioná-la com sua teoria.

Isto o levou, inúmeras vezes, a conversar com Freud. Queria saber se era possível seguir o caminho de suas pesquisas apesar de não considerar a pulsão de morte. A esta pergunta Freud respondia: "Não se preocupe. Continue. Faça o seu trabalho clínico. Não se preocupe" (Reich, 1952, p. 37). Dessa forma, conclui Wagner (1996), a discordância que havia por parte de Reich em relação à teoria psicanalítica era bem circunscrita ao conceito de pulsão de morte, e mesmo assim não alcançava os princípios fundamentais da psicanálise.

Em suma, a importância dada por Reich, desde o início, à questão da energia sexual foi claramente expressa por ele, e a psicanálise delimitou o campo fértil - haja vista a teoria das pulsões - para o autor desenvolver seu ponto de vista acerca dessa questão. Em outras palavras, pode-se dizer que o diálogo entre as teorias de Freud e de Reich acontece no campo pulsional.

É este o ponto de partida, é a partir da pulsão sexual, ou da sexualidade humana, que Reich aprofunda o seu trabalho até circunscrever seu interesse pelo conceito de libido - energia da pulsão sexual. A partir daí passa a arriscar novos passos e desenvolver uma teoria própria, avançando cada vez mais para o campo da biologia, afastando-se de uma psicanálise que, no seu modo de ver, tendia à sociologia e, com isso, apartava-se de suas propostas originárias e originais.

Considerada pois a centralidade do conceito de pulsão na obra dos dois autores, torna-se necessário preliminarmente enfrentar as controvérsias que 
orbitam a delimitação do seu significado. Parcela fundamental das controvérsias tem raiz tradutória, vale dizer, deriva das diferentes opções eleitas pelos tradutores da obra de Freud para traduzir o termo Trieb. Considerável discussão vigora acerca de como o termo Trieb era utilizado popularmente na época de Freud e por que o seu significado interessou tanto ao metapsicólogo, a ponto de ser escolhido para fazer parte do rol dos conceitos fundamentais da psicanálise.

Para responder a essas questões, recorreremos a Luis Hanns (1996), psicanalista e estudioso do vocabulário alemão que compõe os textos de Freud. Num segundo momento, dedicado às traduções do termo Trieb, contaremos com a ajuda de outros autores que irão enriquecer e fornecer novos ângulos sobre o significado de Trieb.

\section{2}

\section{Os significados de Trieb}

A tradução de Trieb é polêmica devido à extensa gama de significados que este termo contém. De acordo com Hanns (1996), tanto na linguagem popular quanto em outros registros de linguagem, empregam-se as palavras Instinkt ou Drang - pressão - como sinônimos de Trieb e, segundo orienta o autor, o próprio Freud, ao longo de toda a sua obra, utiliza os três termos. Isto não é de estranhar a se considerar que durante séculos preponderou na literatura médica a equivalência entre Instinkt e Trieb. No entanto, segundo Hanns (1996), a tradução de Trieb como instinto apenas abrange parte do sentido.

O termo Trieb, enquanto uma palavra corrente da língua alemã, comporta vários significados e a mesma pode ser usada como substantivo ou como verbo (Winograd, 2013). Segundo o Dicionário Comentado do Alemão de Freud (Hanns, 1996), são cinco os principais significados:

1) Força interna que impele continuamente para a ação, ímpeto perene sentia um ímpeto de viver, de viajar, de conhecer novas terras e pessoas;

2) Tendência ou inclinação - ele segue cegamente suas inclinações, sem replicar nada e ninguém;

3) Ânsia, impulso arrebatador - o assassino sentiu um impulso (ânsia) de matar; 
4) Instinto, força inata de origem biológica dirigida a certas finalidades criança tem um instinto de mamar;

5) $\mathrm{Na}$ botânica, o broto que nasce do caule, rebento - um novo broto apareceu esta semana.

Hanns (1999) chama a atenção para o fato de que as definições de Trieb de um modo geral apontam para uma "força impelente dos seres vivos" que se apresenta desde a natureza em geral até o indivíduo singular (Winograd, 2013). Isto é, “abarca um 'arco' que parte do absoluto e grandioso, passa pela espécie e chega ao indivíduo específico" (Hanns, 1999, p. 32). Para ilustrar tal arco, Hanns (1999) sugere classificar didaticamente a manifestação do Trieb em quatro níveis: (1) Princípio geral do vivo ou princípio da natureza - em Freud, pulsão de vida, de morte, etc.; (2) força que se manifesta biologicamente de modo específico em cada espécie - pulsão de reproduzir-se, de mamar, de gregarismo; (3) força que se manifesta na esfera individual - de cunho mais somático: estímulos e sensações manifestos no corpo somático do indivíduo e (4) força que se manifesta na esfera individual - de cunho mais psíquico: algo que se manifesta para o indivíduo, aparecendo subjetivamente como sua vontade ou como um imperativo pessoal.

Hanns (1999) segue sua pesquisa acerca do termo Trieb apontando que este, assim como vários outros termos do idioma alemão, refere-se tanto ao 'agente externo' quanto ao seu efeito percebido internamente "portanto indica a força que impele e a sensação que ela provoca (sob a forma de vontade, impulso, desejo, etc.)" (Hanns, 1999, p. 33). E afirma: "o termo Trieb pode, eventualmente, ser empregado em alemão na acepção de 'instinto', significando uma sequência de ações estereotipadas, mas geralmente quando é usado no sentido de "instinto" refere-se a uma força biológica motivadora que leva os membros da espécie a agir visando sempre à mesma finalidade" (idem, p. 34 - grifo do autor).

Dessa forma quando os termos Instinkt e Trieb se sobrepõem, referem-se tanto aos animais como aos seres humanos, podendo assim, pertencerem tanto à esfera da biologia quanto serem usados para explicar a percepção dos impulsos. No entanto, suas semelhanças terminam aí, pois o instinto sugere algo diferente do termo pulsão - Trieb -, cujo alcance é bem maior e mais amplo. Ou seja, a diferença, sugere Hanns (1999), não é entre aquilo que é biológico-animal e o que é humano, e sim no fato do Trieb abarcar todo o arco, que se inicia na origem como 'força impelente geral dos seres vivos' e termina como 'impulso ou 
tendência do indivíduo', e do instinto conotar a manifestação desta força na espécie como 'tendência de comportamento dirigido a atividades e objetos determinados' (idem, p. 35), não alcançando assim, o nível 'puramente' individual.

Logo, quando Freud utiliza o termo Trieb no sentido de Instinkt, a ideia apresentada é de uma força genérica e impessoal, maior que o sujeito (idem, p. 35). Contudo, no uso psicanalítico do vocábulo Trieb, é importante considerar a multiplicidade de significados deste termo.

A tese de Hanns (1996) esclarece que Freud não exclui quaisquer dos significados de Trieb ao utilizar este termo, pois, na construção de sua teoria psicológica do conceito de pulsão, o metapsicólogo leva em conta três dimensões: psíquica, fisiológica e biológica. E considera a biológica uma dimensão mais abrangente, que pretende dar conta do conceito de pulsão fundamentando-o em todos os seres vivos e a dimensão psicológica, mais específica, que trata desse conceito como uma força econômica que atua especialmente no ser humano, e que tem seus representantes nas ideias e nos afetos.

Segundo Hanns (1999), Freud tentou dar conta, desde o início, de três tarefas: 1) formular um modelo de funcionamento psíquico, 2) estabelecer as bases fisiológicas do psiquismo e 3) situar os fatores biológicos de nosso comportamento. Nesse sentido, Freud procurava estabelecer uma correspondência entre o mundo psíquico e a fisiologia. Apesar de nem sempre ter sido possível estabelecer essa correlação, em virtude das limitações científicas na época, Freud (1914) manteve um modelo energético-econômico que pressupõe uma relação entre os processos psíquicos e o sistema nervoso:

... devemos recordar que todas as nossas ideias provisórias em psicologia presumivelmente algum dia se basearão numa subestrutura orgânica. Isso torna provável que as substâncias especiais e os processos químicos sejam os responsáveis pela realização das operações da sexualidade, garantindo a extensão da vida individual na da espécie. Estamos levando esta probabilidade em conta ao substituirmos as substâncias químicas especiais por forças psíquicas especiais (Freud, 1914, p.86).

Hanns (1999) resume bem as intenções de Freud (1914) ao sublinhar que, para o psicanalista, não bastava que a psique e a fisiologia das pulsões fossem relacionáveis entre si, era preciso ter em mente a possibilidade de estarem, ambas, situadas na biologia da espécie. 
Para ilustrar essa correlação, Freud (1915) apresenta alguns exemplos de quanto a teoria pulsional pode ser interpretada como apoiada no orgânico e de que modo o orgânico pode servir de ponto de partida para ilustrar fenômenos psíquicos. Na primeira teoria pulsional, sugeriu que as pulsões sexuais fossem 'apoiadas' nas pulsões de auto-conservação destinadas a preservar o indivíduo pois suas primeiras manifestações se confundem com as necessidades fisiológicas de qualquer mamífero (respirar, alimentar, defecar). "Aprendemos, assim, que os instintos sexuais encontram seus primeiros objetos ao se apegarem (Anlehnung) ${ }^{3}$ às apreciações feitas pelo instinto do ego, precisamente no momento em que as primeiras satisfações sexuais são experimentadas em ligação (Anlehnung) com as funções necessárias à preservação da vida" (Freud, 1912, p. 186).

$\mathrm{Na}$ segunda teoria pulsional, apresentada em 1920, no texto 'Para além do princípio do prazer', Freud parte de exemplos da biologia, citando inclusive experimentos com protozoários, para ilustrar sua teoria de que até no reino animal há uma compulsão a repetir e que os processos internos conducentes à morte ocorrem em todos os seres vivos, até nos seres unicelulares. Em 1922 no texto 'Dois verbetes de enciclopédia' Freud expressamente nos diz o seguinte:

\begin{abstract}
Embora a psicanálise via de regra se esforce por desenvolver suas teorias tão independentemente quanto possível das outras ciências, é contudo obrigada a procurar uma base para a teoria dos instintos na biologia". (...) "Segundo este ponto de vista, um dos conjuntos de instintos, que trabalham essencialmente em silêncio, seriam aqueles, cujo objetivo é conduzir a criatura viva à morte e, assim, merecem ser chamados de 'instintos de morte'; dirigir-se-iam para fora como resultado da combinação de grande número de organismos elementares unicelulares e se manifestariam como impulsos destrutivos ou agressivos (Freud, 1923 [1922], p. 274).
\end{abstract}

Do ponto de vista do método, o que move Freud (1915) é explicar o conflito psíquico, ou seja, o conflito pulsional que sempre esteve calcado no modelo dualista - primeiramente o conflito se dava entre pulsão de autoconservação e pulsão sexual e depois entre pulsão de vida e pulsão de morte.

É este (conflito pulsional) que ele pretende encontrar na forma mais irredutível expresso como um combate de dois princípios ou duas pulsões básicas. Portanto sua busca vai além das grandes pulsões das espécies, é por uma teoria pulsional geral que se aplique a todos os viventes (...). Tal sistema de forças pulsionais, para ser impelente, deveria ser gerador de tensão, ou, na linguagem afetiva, de conflito;

\footnotetext{
${ }^{3}$ A palavra Anlehnung foi colocada aqui para designar 'apoio', haja vista que na tradução deste trecho por Laplanche e Pontalis (1982), onde aparece 'se apegarem' e 'em ligação', eles utilizam 'apoiados' e 'apoiando-se' (Anlehnung), respectivamente, sugerindo que este foi o termo utilizado por Freud no original alemão.
} 
portanto, o dualismo conflituoso tinha que ser encontrado também na própria base pulsional (Hanns, 1999, p. 39).

Finalmente, com os pares opostos 'pulsão de vida' e 'pulsão de morte', Freud (1920) se aproxima do que pretendia “... com uma teoria pulsional, além do mundo psíquico, da esfera fisiológica, e do patamar biológico das espécies, a dimensão mais geral das leis da vida - e morte -, portanto, dos sentidos irredutíveis e últimos das pulsões" (Hanns, 1999, p. 40).

Vale lembrar que no texto 'Sobre o narcisismo: uma introdução', de 1914, um dos textos que marcam a passagem da primeira para a segunda teoria pulsional, Freud (1914) deixa claro que a clínica psicanalítica é o ponto de partida e também o critério de validação da teoria.

Tento em geral manter a psicologia isenta de tudo que lhe seja diferente em natureza, inclusive das linhas biológicas de pensamento. Por essa mesma razão, gostaria, nessa altura, de admitir expressamente que a hipótese de instintos (pulsões) do ego e instintos sexuais separados (isto é, a teoria da libido) está longe de repousar, inteiramente, numa base biológica, extraindo seu principal apoio da biologia. Mas seria suficientemente coerente [com minha norma geral] para abandonar essa hipótese, se o trabalho psicanalítico vier a produzir alguma hipótese mais útil sobre os instintos. Até agora isso não aconteceu (...). Visto não podermos esperar que outra ciência nos apresente as conclusões finais sobre a teoria dos instintos, é muito mais objetivo tentar ver que luz pode ser lançada sobre esse problema básico da biologia por uma síntese dos fenômenos psicológicos (Freud, 1914, p. 86).

Hanns (1999) defende que o uso do termo Trieb, que abarca desde aspectos gerais até fenômenos individuais, corresponderia às pretensões de Freud de criar um constructo teórico que desse conta da tarefa de abranger os fatores biológicos do nosso comportamento, as bases fisiológicas do psiquismo e que explicasse o funcionamento psíquico. No entanto, apesar da amplitude conceitual do termo, é da posição de uma pulsão que se situa entre o somático e o psíquico - ou, citando Hanns (1999), "entre a biologia e a cultura" - que Freud sempre irá tratar.

Para compreender de qual pulsão fala Freud, ou seja, quais os aspectos do trajeto pulsional interessam à psicanálise freudiana, convém considerar que à psicanálise, como método, cabe a investigação dos processos psíquicos. Assim, a referência sempre é o nosso psiquismo, mesmo quando se trata de fenômenos pulsionais ainda não representáveis ou simbolizáveis, ou seja, mesmo quando nos deparamos com a mais pura descarga pulsional, ainda assim, o objetivo será circunscrevê-la, ligá-la, representá-la e simbolizá-la psiquicamente. 
Dessa forma, alerta Hanns (1999), embora o ponto de partida da clínica sejam os fenômenos decorrentes de conflitos psíquicos que refletem as tramas pulsionais subjacentes, não há como ignorar todos os campos de manifestação da pulsão, caso contrário corre-se o risco de esvaziar o próprio conceito de pulsão. Retomando o texto de 1914 sobre o narcisismo, Freud (1914) afirma:

O indivíduo leva realmente uma existência dúplice: uma para servir as suas próprias finalidades e a outra como um elo numa corrente, que ele serve contra sua vontade ou pelo menos involuntariamente. $\mathrm{O}$ indivíduo considera a sexualidade como um dos seus próprios fins, ao passo que, de outro ponto de vista, ele é um apêndice de seu germoplasma, a cuja disposição põe suas energias em troca de uma retribuição de prazer. Ele é o veículo mortal de uma substância (possivelmente) imortal - como o herdeiro de uma propriedade inalienável, que é o único dono temporário de um patrimônio que lhe sobrevive. A separação dos instintos sexuais dos instintos do ego simplesmente refletiria essa função dúplice do individuo (Freud, 1914, 85-86).

Assim, valendo-se do conceito de 'arco' proposto por Hanns (1999) para circunscrever todos os significados de Trieb, a substância imortal, descrita por Freud (1914), representaria a ideia de absoluto e grandioso abarcada pelo vocábulo alemão - ideia esta que, por sua generalidade, ou seja, por transcender o indivíduo, esbarra no limite da psicanálise, e se encontra com o biológico. Dessa forma, Freud (1914) considera que no ser humano atuariam duas forças, duas realidades, a quem o indivíduo serviria: uma imortal - geral (biológica) - e a outra, individual - mortal (psíquica).

Embora o texto sobre o narcisismo (1914) tenha sido escrito antes da formulação da segunda teoria pulsional, pode-se pensar o narcisismo também nos termos do par 'pulsão de vida' e 'pulsão de morte'. No entanto, nesta segunda versão, a "substância (possivelmente) imortal", associada à pulsão sexual, pode ser pensada como a própria pulsão de morte, haja vista a sua tendência a retornar ao estado inorgânico - à matéria inanimada, imortal; ao estado zero de tensão supostamente já experimentado. Já a pulsão de vida representaria a perturbação desta ordem - deste estado livre de tensão - e a incorporação desta perturbação observada nos processos de carga e descarga, de prazer e desprazer, naquilo que se move em direção a algo, na ligação. Dessa forma, a existência dúplice se faz presente, neste novo contexto, nos conflitos entre: avançar/retornar, criar/repetir, construir/destruir, unir/separar, provocados por Eros e Thânatos.

Além de Hanns (1996) outros autores se empenharam em esclarecer o que Freud quis dizer ao usar o termo Trieb para compor o quadro dos conceitos 
psicanalíticos. Esta tentativa de esclarecimento é fundamental, pois, além de apontar o 'espírito', a intenção que permeia os textos freudianos, também esclarece - mesmo com tantas controvérsias - o melhor termo a ser colhido para revelar este conceito. E essa discussão se mostra bastante rica, pois a análise dos diferentes pontos de vista acerca da tradução de Trieb expande a compreensão, mostrando outras facetas e conexões possíveis que esta palavra sustenta com toda a obra de Freud, além de influenciar quem quer que a use, considerando o contexto psicanalítico.

\section{3}

\section{As traduções de Trieb na obra de Freud}

Como visto antes, a palavra Trieb contém uma enorme gama de significados. Por ser exclusiva do léxico alemão, revela-se uma tarefa desafiadora reproduzir a sua miríade de significados utilizando uma única palavra do léxico português. Por tal razão, gravita tanta controvérsia em torno das traduções da obra de Freud, especialmente em relação ao emprego deste termo.

Segundo Pedro Tavares (2012), apesar da versatilidade e da erudição que se destacam no estilo ou na escrita de Freud, a terminologia, os elementos fundamentais da metapsicologia, os conceitos fundamentais por ele empregados eram, “... muito mais 'familiares' e 'comuns' no contexto de sua cultura e língua de expressão do que se tende a imaginar a partir das traduções mais difundidas" (Tavares, 2012, p. 119). E isto é compreensível, haja vista que o tipo de ‘tratamento psíquico' proposto por Freud (1901) é sobre e para as 'questões da vida cotidiana'.

Tavares (2012) também esclarece que Freud raramente fazia uso das chamadas 'línguas clássicas', do latim e do grego, como é verificável na literatura científica. No entanto, a tradução de James Strachey - Standard Edition - faz crer o contrário; "Freud nunca falou em anáclise (anaclisis), e sim em apoio (anlehnung), nunca mencionou um neologismo de origem grega como catexia (cathexis), mas tratou de algo acessível como a ideia de ocupação ou investimento (besetzung)" (Tavares, 2012, p. 119).

Ivan Ramos Estevão (2012) endossa a observação de Tavares (2012), considerando a tradução inglesa de Strachey com muitos erros primários, como a 
inversão de frases, alteração de contextos e, "a escolha infeliz de certos termos que transformam a escrita fluente de Freud em um emaranhado estranho e pseudocientífico" (Estevão, 2012, p. 80). Estevão (2012), também, completa a lista de Tavares (2012), lembrando que nas Obras Completas traduzidas do inglês para o português, tanto Verdrängung como Unterdrückung foram traduzidos como repressão; Ich, Überich e Es foram substituídos pelos termos latinos Ego, Superego e Id; Kultur foi traduzida por civilização e, finalmente, Trieb por instinto. (Estevão, 2012, pp. 80-81).

De acordo com Paulo César de Souza (2009), no alemão culto sempre houve a incorporação de palavras gregas e latinas, inclusive o vocabulário filosófico alemão, criado por Christian Wolff na primeira metade do século XVIII, foi fundamentado no latim. Assim, “Instinkt foi adotado durante o século XVIII e passou a fazer parte do vocabulário culto, enquanto no vocabulário tradicional, Trieb, era - é - mais usado coloquialmente" (Souza, 2009, pos. 4073 de 5335).

Portanto, seguindo o raciocínio destes autores, Freud era conhecedor das línguas clássicas - afinal, a educação de Freud, sem dúvida, foi impregnada pela educação austríaca da época (centralizada no Gymnasium) onde se cultivava o amor e o rigor na pesquisa (Souza, 2009, pos. 316 de 5335). Logo, foi uma opção do próprio autor priorizar termos comuns e 'populares' para designarem seus conceitos psicanalíticos, em detrimento de estrangeirismos, ainda que considerados pelo meio científico como mais apropriadas para confeccionar o edifício teórico de sua obra científica.

É de se indagar então por que razão Strachey (1969) optou por traduzir Trieb por Instinct, se o próprio Freud, deliberadamente, rejeitou este termo - salvo em poucas passagens de sua obra.

Strachey (1969) reconhece que sua tradução tem sido atacada por diversas pessoas de forma muito severa e considera este ataque um equívoco. Segundo o tradutor, o termo proposto pelos críticos como alternativa à Instinct é Drive (impulso). Acontece que, na ocasião em que foi realizada a tradução, a palavra Drive usada no sentido de Impulse, além de não ser uma palavra inglesa, também não configurava como tal no grande dicionário de Oxford e nem em compêndios de psicologia em língua inglesa. (Strachey, 1969a, p. 31).

Segundo Strachey (1969a), "Freud usou a palavra Trieb para abarcar vários conceitos diferentes" (Ibid. p. 31), no entanto, completa ele: "não é da 
competência do tradutor tentar classificar e fazer distinção entre os diferentes usos que Freud fazia da palavra. Essa tarefa seguramente pode ser delegada ao leitor, desde que a mesma palavra inglesa seja invariavelmente usada para o original alemão" (ibid., p. 32). Além do mais, Freud deixa bem claro o que quer dizer com a palavra Trieb, tanto nos 'três ensaios' (1905) quanto em 'Instinto e suas vicissitudes' (1915). Por isso Strachey (1969a) considerou sensato escolher uma única palavra - Instinct - para traduzir Trieb e, quando no texto original a palavra Instinct aparecia, chamava-se a atenção numa nota de rodapé.

Ou seja, o termo Trieb, ao ser elevado à categoria de conceito psicanalítico, concentra em si o significado proposto por Freud. Assim, ao se deparar diante do termo Instinct - na tradução inglesa das obras de Freud - o significado correlato que deveria vir à mente é o de um "conceito situado na fronteira entre o mental e o somático, como o representante psíquico dos estímulos que se originam dentro do organismo e alcançam a mente, no sentido de trabalhar em consequência de sua ligação com o corpo" (Freud, 1915, p. 127).

E para não deixar dúvidas, Strachey (1969b) escreve o seguinte no prefácio de 'Instinto e suas vicissitudes' (1915): “Deve-se observar, à guisa de prefácio, que aqui (e através de toda Standard Edition) o termo inglês Instinct representa o alemão Trieb! (...) A palavra 'instinto', de qualquer maneira, não é empregada aqui no sentido que parece no momento ser o mais corrente entre os biólogos. Mas Freud assinala, no decorrer desse artigo, o significado que atribui à palavra assim traduzida" (Strachey, 1969b, p. 117).

Paulo César de Souza (2009), também se põe de acordo com a tradução de Trieb por 'instinto' - “... proponho sem reservas o recurso a 'instinto' para verter Trieb" (Souza, 2009, pos. 4149 de 5335). De acordo com o autor a principal crítica à tradução por 'instinto' foi elaborada por teóricos franceses da psicanálise - que atribuíram a essa escolha uma pretensão de biologizar a psicanálise. Assim, a partir de Jaques Lacan, e principalmente com a publicação do "Vocabulário de Psicanálise' (Laplanche e Pontalis), a palavra 'pulsão' foi adotada como alternativa para traduzir Trieb (Souza, 2009).

Laplanche e Pontalis (1982), defensores do termo Pulsion para traduzir Trieb, justificam a escolha por este termo: "Em francês, o termo Instinkt [assim como em português o termo instinto] tem as mesmas implicações que o termo Instinkt tem em Freud e deve, portanto, na nossa opinião, ser reservado para 
traduzi-lo; se for utilizado para traduzir Trieb, falseia o uso da noção em Freud" (Laplanche e Pontalis, 1982, p. 394). Strachey (1969a) não ignora este argumento, inclusive afirma que o termo Instinkt, quando aparecia nos escritos de Freud era efetivamente utilizado no sentido de 'instinto nos animais' (Strachey, 1969a, p. 32). No entanto, mesmo tendo ciência dessa circunstância, o tradutor inglês considerou Instinct a melhor versão.

Souza (2009), lançando mão de um ensaio crítico escrito por Eugenio Coseriu (1976) sobre os 'problemas da tradução', elucida as variáveis com as quais o tradutor precisa lidar em face das distintas acepções e inúmeras possibilidades interpretativas reveladas durante o trabalho tradutório. Dessa forma, Souza (2009) sintetiza os pontos fundamentais: em primeiro lugar é importante considerar dois pontos: primeiro, com frequência, os conteúdos de duas línguas não se equivalem - por exemplo o verbo to know pode significar 'saber' ou 'conhecer' -, e, segundo, é que existem termos intraduzíveis, como 'saudade' em português ou esprit em francês. Por isso, a tradução tem por meta expressar um mesmo conteúdo de texto em línguas diferentes, e não substituir um termo singular por outro tal como encontramos em dicionários bilíngues, ou seja, o que importa é o sentido do termo identificado num dado contexto, e não a sua tradução literal, que muitas vezes pode mudar o espírito do texto.

Dessa maneira, a tarefa do tradutor seria o de reproduzir a mesma designação e o mesmo sentido com os meios de outra língua (Souza, 2009). Lembrando que 'designação', segundo o autor, é diferente de 'significado'. Este último é o conteúdo dado somente por uma determinada língua, diferente da 'designação' que 'toca a coisa extralinguística; é alcançável apenas mediante significados linguísticos, mas não coincide com eles" (Souza, 2009, pos. 4211 de $5335)$.

Isto posto, tendo em mente o termo Trieb, pode-se concluir que este, tal como o termo português saudade, possui significado intraduzível, mas pode-se transpor a sua designação. Com isso, a tarefa do tradutor é descobrir qual o sentido dado por Freud a Trieb, e encontrar no léxico de outra língua uma maneira de transmitir seu espírito.

Souza (2009) propõe, então, o seguinte exercício: imagine "perguntar a um grupo de pessoas o que lhes evoca o termo 'instinto', e depois fazer o mesmo com ‘pulsão'. A rede semântica do primeiro seria bem mais rica, ligando-se aos 
campos léxicos de 'impulso', 'sexo', 'ímpeto' etc... O mesmo não acontecendo com o segundo" (Souza, 2009, pos. 4102 de 5335).

Este exercício serve para mostrar que na língua portuguesa, no vocabulário ordinário, a palavra 'instinto' evoca um numero muito maior de palavras e significados, causando uma sensação muito mais próxima daquela evocada pelo termo Trieb no falante de língua alemã, do que o termo pulsão. Além disso, Souza (2009) contra argumenta com o que considera ser a principal objeção a instinto, isto é: Freud teria feito uma distinção clara entre o que seria 'instinto dos animais' e o 'Trieb no humano'.

Para o autor o termo 'instinto' na obra de Freud dá margens a equívocos, como mostra o exemplo a seguir, extraído do texto 'O Inconsciente' (1915): “O conteúdo do inconsciente, pode ser comparado à presença de uma população aborígine na mente. Se existem no ser humano formações mentais herdadas - algo análogo ao instinto nos animais - elas constituem o núcleo do inconsciente" (Freud, 1915, p. 200). Apesar do cuidado ao usar o termo 'análogo' - ou seja, é semelhante, parecido, aproximado ao instinto dos animais, mas não 'igual' -, o fato de considerar a existência de 'formações mentais herdadas' no humano, faz pensar que de fato exista um 'instinto' humano manifestado em nossa herança. Assim, Souza (2009) conclui que fazer distinção entre Instinkt dos animais e Trieb dos humanos é ignorar partes importantes da obra de Freud, onde o autor chega a considerar, inclusive, que tantos os bichos quanto os homens compartilham de um sistema inconsciente. (Souza, 2009, pos. 4134 de 5335).

Na contramão dos tradutores que resistem em traduzir Trieb por pulsão, encontramos o psicanalista Ivan Ramos Estevão (2012). Estevão (2012) defende que a opção por traduzir o termo Trieb por 'instinto' ou 'pulsão' se dá por motivos políticos, pois a escolha do primeiro ou do segundo termo causa diferentes efeitos tanto teóricos quanto clínicos, na teoria freudiana.

O autor alega que hoje em dia a palavra instinto se popularizou vinculada à ideia de algo genético, ou seja, inato, diferentemente da época de Freud, quando a palavra instinto aproximava-se mais da ideia de impulso. Com isso, ainda que se adotem os cuidados empreendidos por Strachey (1969) com o intuito de atribuir à palavra instinto, no contexto psicanalítico, um significado próprio que difere do uso popular, esses cuidados, segundo Estevão (2012), não são suficientes para evitar confusões. A seu ver este assunto se torna ainda mais sério a se considerar 
que a opção por 'instinto' pode levar o leitor de Freud a uma compreensão equivocada de suas ideias.

Para ilustrar o seu argumento, pegamos emprestado um dos exemplos citados por esse autor, a questão do desejo e da responsabilidade, em relação à qual Estevão (2012) declara fazer significativa diferença considerar Trieb como instinto em vez de pulsão. O termo 'instinto' levaria ao entendimento de Trieb como algo inato, e com isto, a ideia de desejo estaria comprometida - "o desejo seria a articulação mediada pela representação e pelo afeto, entre Trieb e a fantasia" (Estevão, 2012, pp. 87, 88). É como se, vertendo Trieb por instinto, o desejo seria considerado congênito, logo, as atitudes do indivíduo que iriam ao encontro deste 'desejo instintivo', seriam pré-determinadas e não poderiam ser refreadas. Isto posto, a responsabilidade por nossos desejos seria dos ancestrais, da hereditariedade, que exerceria uma força instintiva que submeteria os indivíduos.

E isto vai contra tanto a própria definição de Trieb apresentada por Freud (1915) - onde o alvo (Ziel) e os objetos são múltiplos e variáveis, apesar de objetivarem a satisfação - quanto contra a consequência clínica que esta multiplicidade de objetos e variedade de formas de se chegar à satisfação, acarreta.

Assim, justifica o autor:

A ideia de instinto põe em cheque a questão da responsabilização e, portanto, tende a pôr em cheque a noção de desejo tal como formulada por Freud. A noção de instinto parece vincular a ideia de desejo a um conteúdo pré-definido, como se o Trieb fosse ligada de forma herdada a uma fantasia também herdada. Isso parece ser contrária à posição freudiana.

Logo, a tradução de Trieb por instinto ao invés de pulsão não remete a uma questão apenas técnica, mas a uma tomada de posição, que diminui (ou acaba) com $\mathrm{o}$ componente referente à responsabilidade. $\mathrm{O}$ instinto seria algo natural e irrefreável, enquanto Freud afirma constantemente as diversas formas de refrear, modificar e alterar a pulsão. Pagamos um preço por esta interdição, por essa perda de satisfação, mas é a partir daí que se pode falar de uma teoria da responsabilidade. Se Trieb é entendida a partir do desejo inconsciente, não se trata de algo inscrito em termos de uma genética, mas justamente de algo que desvia do biológico (Estevão, 2012, p. 91).

Estevão (2012) segue justificando a sua predileção pelo termo pulsão, fazendo uma crítica àqueles que consideram Trieb - um conceito entre o psíquico e o somático - como um ponto localizado no limite dos elementos naturais do corpo e, portanto, como algo da ordem do biológico. Com isso, a questão proposta 
por ele é: de que corpo falamos? Ao recordar os fenômenos histéricos, Estevão (2012) retorna ao início das obras de Freud, aos estudos sobre a histeria, onde o corpo parece não responder totalmente à biologia, pois o fenômeno observado "confunde, subverte, critica o discurso anatômico e fisiológico da medicina" (Estevão, 2012, p. 92).

Vale lembrar que a cegueira histérica e a paralisia, tão comum nas conversões, não guardavam correspondência orgânica, nada havendo no corpo biológico que indicasse o motivo de tais afecções. Logo, a ideia de corpo para a psicanálise - originando-se na histeria - é um corpo erotizado, um corpo que responde à lógica dos impulsos sexuais recalcados, e não à lógica anatomofisiológica. "Se é deste somático que Freud fala ao longo de sua obra, um somático invadido pela psique, então Trieb parece estar mais fortemente ligada ao termo pulsão" (Estevão, 2012, p. 92).

Outro argumento importante apontado por este autor diz respeito à questão da hereditariedade. Este conceito é trabalhado por Estevão (2012) no sentido de provar que, se o fator hereditário fosse relevante na constituição de uma neurose, traduzir Trieb por instinto seria o mais correto. Haja vista que 'herdar' uma doença, ou seja, tê-la adquirida geneticamente, aproximaria a causa da neurose à biologia e ao orgânico e a afastaria do psiquismo inconsciente, construído pelo ambiente, pela cultura.

Esta diferença gera efeitos clínicos distintos, pois, uma doença que não é herdada mas adquirida, é passível de tratamento. Quanto a isso, Freud (1895) deixa bem claro:

De acordo com as concepções de Loewenfeld e de inúmeros outros, a etiologia dos estados de angústia deve ser buscada na hereditariedade. Ora, a hereditariedade é certamente imune a alterações; logo, se a neurose de angústia é curável sobre tratamento, temos que concluir, segundo a argumentação de Loewenfeld, que sua etiologia não pode residir na hereditariedade (Freud, 1895, p. 130).

O autor não ignora as menções à biologia feitas por Freud ao longo de sua obra, mas pondera que, em Freud, a hereditariedade - ou seja, o papel do biológico - se torna o limite da teoria psicanalítica. "Ela entra em momentos em que não é mais possível avançar em termos técnicos e conceituais, logo, a hereditariedade é um conceito adhoc, quer dizer, funciona como 'tampão' para problemas insolúveis. (...) Contudo, o fato é que Freud nunca abre mão completamente dela como recurso para certas situações" (Estevão, 2012, p. 99). 
Em suma, Estevão (2012) conclui que "Trieb sofre constantemente as vicissitudes da socialização e da cultura, bem mais intensamente do que as da biologia" (Estevão, 2012, p. 101). Por isso, concorda com a opção de traduzir Trieb por pulsão, cuja acepção permite pensar o homem como um ser mais cultural; harmoniza-se com a técnica que diz respeito à responsabilização diante do desejo; distancia-se da ideia de uma natureza humana e aponta para dois princípios centrais do conceito de Trieb: a pulsão constante (konstante kraft) e seu efeito de pressão (drang), que leva a um impulso (Estevão, 2012, p. 101).

Além disso, Estevão (2012) esclarece a sua declaração, alegando que a escolha dos tradutores é política, pois implica em uma tomada de posição diante do texto freudiano, que interfere na compreensão da origem das patologias psíquicas e, consequentemente, na forma de tratá-las. Assim, a posição adotada por Souza (2009) - sobre o instinto ser uma palavra mais 'popular' e que remete a um número maior de significados - é expressamente contestada por Estevão (2012) que sustenta o argumento de ser a 'pulsão' justamente um termo menos conhecido e por isso se torna a melhor escolha. "Não havendo uma palavra que se encaixe em Trieb e, sendo ela, uma palavra aberta a tantas possibilidades, que dá margem a tantas especulações, nada melhor do que propor uma nova palavra. Pulsão claramente já se tornou conhecida como ‘tradução' de Trieb” (Estevão, 2012, p. 103).

Outra possibilidade seria não traduzir Trieb nem por instinto e nem por pulsão, mas por impulso. Este é o termo sugerido pelo tradutor Renato Zwick (2010) em entrevista à editora 'L\&PM' - para a qual traduziu o texto freudiano 'o mal estar na cultura' (1930). Segundo o tradutor, se a ideia for traduzir Freud diretamente do alemão para o português - sem passagem pela tradução inglesa que verte Trieb por instinct, ou a francesa que considera pulsion a melhor versão - o termo que melhor se encaixaria na versão nacional de Trieb seria impulso; "acho que o uso de um neologismo só se justificaria se não tivéssemos um bom equivalente como impulso" 4 (Zwick, 2010).

Pedro Tavares (2012), esclarecendo a escolha feita por Zwick (2010), revela que este utilizou o dicionário de Hanns (1996) como referência para extrair os 
significados de Trieb: "impelir, impulsionar, tocar a frente" (Tavares, 2012, p. 124). Assim, faz mais sentido para o tradutor verter Trieb por impulso, afinal este termo "parece-nos, cobre perfeitamente os vários matizes de sentido da palavra alemã” (Zwick, 2010, pp. 190, 191).

Como vimos, não há um consenso a respeito da melhor escolha para a tradução de Trieb. Alguns tradutores se atêm às regras clássicas da tradução e colhem no léxico português a palavra que melhor equivaleria, em 'espírito', ao termo alemão. Outros vão investigar nas minúcias dos termos usados por Freud a razão de utilizarem esta ou aquela palavra. Há ainda os que reconhecem se tratar de uma escolha política, no sentido de uma 'tomada de partido', com base na interpretação que fazem dos textos freudianos - se o autor tende a interpretar os textos sob a ótica da biologia, faz mais sentido usar 'instinto', no entanto, se a interpretação for mais sociológica, cultural, o termo 'pulsão' seria mais adequado.

Porém, não é só na obra de Freud que a tradução de Trieb causa controvérsias. Ao tratar sobre este conceito na obra dos dois autores - Freud e Reich -, cabe aqui investigar, também, como este termo foi traduzido nos textos reichianos, e qual o 'ponto de vista' adotado por estes tradutores.

\section{4}

\section{As traduções de Trieb na obra de Reich}

Nos textos produzidos durante os quatorze anos em que Reich foi filiado à Sociedade de Psicanálise, em todos aqueles em que o autor menciona ou trata sobre a 'pulsão', constata-se que o termo utilizado originalmente é Trieb. Assim, a questão colocada aqui versa sobre os termos utilizados para traduzir Trieb na obra reichiana, considerando a opinião de seus tradutores.

Analisando o livro escrito por Sara Q. Matthiesen (2007) destinado a organizar bibliograficamente a obra de Wilhelm Reich, é possível contrapor alguns títulos originais de língua alemã com suas traduções para o inglês e o português. Por exemplo, o título do texto "Trieb und Libidobegriffe von Forel bis Jung" (1922), foi traduzido para o inglês como "Drive and Libido concepts from Forel to Jung" - aqui, na tradução de 1975, o tradutor Philip Schmitz utiliza a palavra Drive como equivalente de Trieb. Em português a tradução deste título é “Os conceitos de Impulso (Pulsão) e Libido de Forel a Jung” (Matthiesen, 2007, 
p. 52), tendo a autora equiparado Trieb a Impulso, contudo, utilizando o termo 'pulsão' entre parênteses. Outro exemplo é o título "Zur Trieb-Energetik" traduzido em 1975 para o inglês por "Concerning the Energy of Drives", e para o português por "Sobre a Energética dos Impulsos" (Matthiesen, 2007, p. 53).

Apesar das observações de Strachey (1970), não é difícil observar nos textos de Reich traduzidos para o português a partir do inglês, a presença marcante da palavra drive, a qual muitas vezes, é traduzida como "pulsão". Assim, quando traduzidos para o português, termos como drive denial e drive gratification, presentes, por exemplo, em Reich (1925/1975), aparecem como "frustração da pulsão" e "satisfação da pulsão" (Reich, 1925/2009) (Matthiesen, 2010, p. 3).

A escolha pelo termo drive não ocorreu à toa. Muito já se falou sobre a tradução de Trieb por Instinct, contestada por vários autores, como já demonstrado. Dessa forma, considerando que as traduções para a língua inglesa das obras de Reich foram feitas nos Estados Unidos e não na Inglaterra, a palavra drive surgiu como alternativa ${ }^{5}$, já que não carrega um significado exclusivamente biológico. Conforme o Longman Dictionary of Contemporary English (1994), o vocábulo drive tem as seguintes definições: (1) mover ou viajar em um veículo; guiando-o e controlando-o; (2) levar alguém em um veículo; (3) forçar (to force) a ir, por exemplo: um fazendeiro força o gado a ir para o pasto, ou, a falta de pão provavelmente irá forçar o aumento dos preços; (4) prover de força (power) para, por exemplo: o motor força o barco; (5) mover-se com grande força; dentre outros. Drive também pode ser traduzido por: "uma necessidade humana, importante, que deve ser atendida, exemplo: fome, sede e sexo, estão entre os mais fortes impulsos humanos" (Longman dictionary, 1994, p. 313).

Assim, a palavra Drive abarca diversos sentidos: conduzir, dirigir, guiar, mover, movimentar, impelir, etc. Estes significados vão ao encontro da definição de pulsão descrita por Laplanche e Pontalis como sendo um "processo dinâmico que consiste numa pressão ou força (carga energética, fator de motricidade) que faz o organismo tender para um objetivo" (Laplanche e Pontalis, 2001, p. 394), concordando com o significado geral de Trieb - "força impelente dos seres vivos" - tal como observado por Hanns (1999). Portanto, Drive cabe como conceito para traduzir a palavra Trieb, uma vez que também se trata de uma força que impele, sem descaracterizar o sentido psicanalítico deste termo.

\footnotetext{
${ }^{5}$ Lembrando que, como o próprio James Strachey afirmou, na época, Drive não era uma palavra tão comum no léxico inglês (britânico), como Instinct. Isto seria mais uma razão que favoreceria a escolha por Instinct ao invés de Drive.
} 
Contudo, segundo Ricardo Amaral Rego (1995), algumas traduções inglesas do termo Trieb, utilizavam além de drive a palavra Instinct, Impulse e, às vezes, até libido. Rego, responsável pela mais recente tradução do livro 'Análise do Caráter', manteve-se fiel às raízes psicanalíticas de Reich e traduziu Trieb por 'pulsão', uma vez que, como sugere Matthiesen (2007), “os textos reichianos que se pautam na utilização desse termo estão, muitas vezes centrados no 'período psicanalítico' de Reich, quando este fazia uso de termos utilizados também por Freud" (Matthiesen, 2007, p. 4).

A tradução portuguesa utiliza tanto pulsão, quanto impulso, e também instinto. Por exemplo, no livro: "Psicopatologia e Sociologia da vida sexual" de 1927 (editora Global, São Paulo, s.d.), o tradutor optou por traduzir Trieb por “instinto”. No capítulo VII, onde se lê: “O Instinto de Destruição depende da Estase Libidinal" (p. 209), no original está escrito: "Die Abhängigkeit des Destruktionstriebes von der Libidostauung" (Reich, 1927, p.152). No mesmo texto, no original, observamos a seguinte frase: "Freud hat in seinem Buche über "Das Ich und das Es" die zwei Grundtriebe: den Eros und den Todestrieb (Sexualtrieb - Destruktionstrieb, Liebe - HaB) als polare, den Organismus (...)" (Reich, 127, p. 152).

A tradução para o português ficou assim: "No livro "o Ego e o Id", Freud apresenta os dois instintos fundamentais - Eros e o instinto de morte (instinto sexual/instinto de destruição, amor/ódio) - como sendo as duas tendências polares que regem o organismo (...)" (Reich, 1927, 209). Outro trecho retirado do mesmo livro diz: "Os instintos que servem de base às leis biológicas estão inscritos no organismo, e só o momento, o modo e a intensidade de sua emergência dependem da experiência individual” (Reich, 1927, p. 213), no original, esta frase corresponde à seguinte: "Sämtliche den biologischen Gesetzen unterliegenden Triebe sind in der Anlage gegeben und nur der Zeitpunkt, die Art und Intensität ihres Erscheinens hängen von den Erlebnissen ab.” (Reich, 1927, p. 156).

De acordo com Hanns (1996), o termo Trieb não tem uma correspondência tal e qual na língua portuguesa, por isso, optou-se pela tradução 'pulsão' que seria uma palavra possível de refletir os significados projetados por Trieb, sem correr o risco de cair num reducionismo. Já a palavra 'instinto' tem o seu correspondente 
em alemão, que é a palavra instinkt. Como podemos constatar o termo utilizado por Reich é Trieb, o que não justificaria a tradução por instinto.

Segundo Ailton Bedani (2007), na obra de Reich seria mais adequado ter Trieb traduzido para 'impulso': “Por remeter à física, 'impulso' é um vocábulo que está, certamente, mais sintonizado com a perspectiva científico-natural que o autor desejou imprimir às suas pesquisas, desde o início da década de 1920”. No entanto, completa o autor: "se adotássemos, para os escritos psicanalíticos de Reich, a tradução de Trieb por 'impulso', acabaríamos introduzindo, em nossas análises, algumas complicações terminológicas e conceituais. Para o bem ou para o mal, a palavra 'pulsão' acabou se consagrando, e acreditamos que uma certa confusão surgiria se utilizássemos 'pulsão' para indicar Trieb em Freud, e ‘impulso’ para designar o Trieb em Reich” (Bedani, 2007, p. 117).

É interessante notar que, apesar de Trieb ser apresentado em diversas versões na obra de Reich, na opinião de Bedani e Matthiesen a melhor tradução de Trieb para o português seria 'impulso', pois ambos estão de acordo de que este termo seria mais fiel às perspectivas científico-naturais com que Reich abordava seus estudos. No entanto, nenhum dos três autores (Bedani, Matthiesen e Rego) faz objeção quanto ao uso do termo 'pulsão' se for considerado, especialmente, para traduzir Trieb dentro do contexto psicanalítico na obra de Reich.

Considerando o 'arco' sugerido por Hanns (1996), o termo Impuls ou Drang (impulso) estaria contido no termo Trieb. Ou seja, sendo Trieb um termo mais abrangente e tendo como um de seus sentidos 'força interna que impele continuamente para a ação, ímpeto perene' (Hanns, 1996), não seria errado usar Trieb no lugar de Impuls. Dessa forma, a decisão para a melhor tradução deste termo na obra de Reich conduz à mesma questão dos tradutores da obra de Freud, isto é, possivelmente traduzir Trieb por 'impulso' produza o mesmo reducionismo, criticado por tradutores, do termo 'instinto'.

É certo que há uma diferença. Nem todos os psicanalistas, tradutores e estudiosos da psicanálise estão de acordo com o termo 'instinto' para verter Trieb, muito pelo contrário, consideram que este pode induzir o leitor de Freud a erro, forçando um olhar biológico à leitura dos textos freudianos, onde muitas vezes não caberia. Já o termo 'impulso', sendo utilizado como Trieb na obra reichiana não passaria por esse problema, uma vez que seus tradutores não o consideram incorreto. A questão é que o próprio Reich usava Trieb, e não Drang ou Impuls. 
Mesmo assim, o maior problema reside na escolha de um termo pouco abrangente, que desprezaria a complexidade de Trieb, com todas as suas nuances tão caras à teoria de Freud. Com isso, poderíamos dizer o mesmo do termo Trieb para Reich, ou seja, tal como Freud, Reich também era de origem germanófona e conhecia muito bem o significado coloquial do termo.

Assim, embora o autor, como será visto ao longo desta pesquisa, adote uma concepção mais 'energético-fisiológica' do conceito Trieb, ele não desconsiderava a complexidade nem do termo e nem do conceito introduzido por Freud, citando inclusive seu significado psicanalítico: "um conceito limite entre o psíquico e o somático, uma representação psíquica do estímulo originando-se dentro do corpo e penetrando a psique, e uma medida das demandas de trabalho sobre a psique devido à sua relação com o corpo" (Reich, 1922, p. 105 - tradução nossa).

Como este trabalho trata da articulação entre os dois autores acerca do conceito Trieb, manteremos a uniformidade tradutória, principalmente porque estamos considerando a obra de Freud como o solo conceitual, de onde irá partir as reflexões sobre as teorias reichianas. Dessa forma acatamos a sugestão de Hanns (1999) e traduzimos, neste trabalho, o termo Trieb por 'pulsão', salvo em citações literais.

Nas próximas páginas será visto o modo como o conceito Trieb se apresenta na obra de Freud. O metapsicólogo, partindo de seu ensaio sobre a sexualidade, vai definir o primeiro modo de ser da pulsão, que é a pulsão sexual. Em 1915, com o advento da primeira teoria pulsional, o autor apresentará então a segunda pulsão primordial que se oporá à primeira, a pulsão de autoconservação, e que terá na fome o seu protótipo.

A ideia de pulsão sexual, em especial, vai ser muito cara a Reich que irá desenvolver a sua primeira grande obra, a 'Função do Orgasmo' de 1927, apoiando-se na teoria da libido freudiana. Assim, como veremos no próximo capítulo, o autor irá enxergar a pulsão sexual por outro prisma, considerando a sua face fisiológica e energética. 


\section{Primeira teoria pulsional: pulsão sexual}

\section{1}

\section{Formando o conceito de pulsão (Trieb)}

Freud utiliza o termo 'pulsão' (Trieb) em vários artigos de suas primeiras publicações ditas pré-psicanalíticas. Mas, somente em 1905 no texto dedicado à teoria da sexualidade, é que este termo iria ganhar um estatuto conceitual propriamente dito.

Garcia-Roza (1995) nota que antes de o conceito ser inaugurado, Freud utilizava com frequência os termos pulsão (Trieb), excitação pulsional (Triebregung), moção de desejo (Wunschregung), estímulo pulsional (Triebreiz), excitação (Erregung), dentre outros, alternadamente, para designar a mesma ideia. No entanto, foi no artigo 'Três ensaios sobre a teoria da sexualidade', que Freud (1905) introduziu o conceito de 'pulsão' ${ }^{6}$, definindo-a como:

Por instinto ${ }^{7}$ podemos entender, a princípio, apenas o representante psíquico de uma fonte endossomática de estimulação que flui continuamente, para diferenciá-la do 'estímulo', que é produzido por excitações isoladas vindas de fora. Pulsão, portanto, é um dos conceitos da delimitação entre o anímico e o físico. A hipótese mais simples e mais indicada sobre a natureza da pulsão seria que, em si mesma, ela não possui qualidade alguma, devendo apenas ser considerada como uma medida da exigência de trabalho feita à vida anímica. O que distingue as pulsões entre si e as dota de propriedades específicas é sua relação com suas fontes somáticas e seus alvos. A fonte da pulsão é um processo excitatório num órgão, e seu alvo imediato consiste na supressão desse estímulo orgânico (Freud, 1905, p. 159).

A fim de aprofundar este conceito que começou a se delinear no horizonte da psicanálise, é importante destacar a seguinte frase, do trecho acima reproduzido, sobre a natureza da pulsão: 'Por instinto (Trieb) podemos entender, a princípio, apenas o representante psíquico de uma fonte endossomática de estimulação que flui continuamente, para diferenciá-la do 'estímulo', que é produzido por excitações isoladas vindas de fora'.

\footnotetext{
${ }^{6}$ Nestes três ensaios, Freud (1905), ao se referir à 'pulsão' está, na verdade, tematizando sobre o conceito de 'pulsão sexual'.

7 O tradutor da versão brasileira das Obras Completas de Freud (Standard Edition) optou por traduzir Trieb por instinto.
} 
Observa-se que Freud (1895) traçou uma clara distinção entre os estímulos endógenos e exógenos que atingem o aparato psíquico. Simplificadamente, os estímulos exógenos são provenientes do mundo exterior e, por isso, antes de chegar ao aparato são amortecidos pelos órgãos dos sentidos. Diferente destes, os estímulos endógenos emanam de fontes no interior do próprio corpo e, por não existir nada que os amorteçam, atingem o aparato diretamente.

Se a exigência do estímulo externo for demasiada ou provocar qualquer desequilíbrio e perturbação à ordem do aparato, este (o estímulo externo) pode ser afastado com a devida ação motora, desviando-se da fonte estimuladora. No entanto, quanto ao estímulo endógeno, isso não é possível. Dessa forma, para resolver os excessos que vêm do próprio corpo, o aparato psíquico se vê obrigado a ter que achar outra solução - que não a fuga motora - para administrar estes estímulos. Essa administração ocorre na medida em que o aparato aprende a dominar, transformar e ordenar as excitações que lhe chegam.

Corroborando essa concepção, Freud (1914), ao introduzir o narcisismo, revela o seguinte:

Reconhecemos nosso aparelho mental como sendo, acima de tudo, um dispositivo destinado a dominar as excitações que de outra forma seriam sentidas como aflitivas ou teriam efeitos patogênicos. Sua elaboração na mente auxilia de forma marcante um escoamento das excitações que são incapazes de descarga direta para fora, ou para as quais tal descarga é, no momento, indesejável (Freud, 1914, p. 92).

Assim, a forma encontrada pelo nosso aparato para se livrar do excesso de estímulos oriundos de dentro do próprio corpo é pela via da elaboração. A elaboração psíquica consiste em transformar a energia livre, do processo primário, em energia ligada (processo secundário). Em outras palavras, esse trabalho se resume em integrar as excitações no psiquismo e em estabelecer entre elas conexões associativas (Laplanche e Pontalis, 1982, p. 143). Uma vez estabelecida essas conexões, a energia passa a utilizá-las como auxiliadoras de seu escoamento. Assim, o estímulo endógeno consegue ser descarregado sem 'transbordar', ou seja, as conexões servem como contenção da energia livre.

Combinando as duas ideias, a saber, a ideia de que o estímulo endógeno pressiona o aparato psíquico e a ideia de que a pulsão consiste em 'uma medida da exigência de trabalho feita à vida anímica', pode-se concluir que a pulsão é um estímulo endógeno. Garcia-Roza (1995), entretanto, ao observar mais atentamente à indicação de Freud (1905), adverte: a pulsão é um estímulo 
endógeno, sim, mas que faz uma exigência ao psiquismo, ou seja, é um estímulo para o psíquico.

No entanto, como a pulsão é algo que de fora - fora do aparato psíquico, porém endógena - faz uma exigência de trabalho ao psiquismo, não é possível considerá-la um 'estímulo psíquico'. Em decorrência disto, Garcia-Roza (1995) aponta que, estando a pulsão externa ao aparato psíquico, ela não se submete aos mesmos princípios que regulam o funcionamento deste aparato, a não ser quando for por ele capturada (Garcia-Roza, 1995, p. 84). Com isso diferencia-se entre a pulsão, ela própria, e a forma como ela (a pulsão) se presentifica no psiquismo.

Essa distinção veio a ser esclarecida por Freud em 1915 no artigo dedicado às vicissitudes da pulsão. As pulsões se manifestam no psiquismo via seus representantes - representante-representação ou ideia (Vorstellung) e representante-afeto (Affekt). Em segundo lugar a pulsão é um estímulo para o psíquico, mas não um estímulo psíquico. Ou seja, a pulsão por si é um conceito fronteiriço e embora se encontre na interseção - entre o psíquico e o somático não pode ser considerada imersa nem no orgânico e nem no aparato psíquico. Por isso, o que se faz presente no psiquismo não é a pulsão, mas seus representantes.

Outro aspecto importante da citação de 1905, apresentada na primeira página deste capítulo, é a distinção elaborada por Freud (1905) entre a fonte pulsional e o alvo da pulsão, representando a fonte a origem somática do estímulo e o alvo, a supressão da excitação orgânica na fonte. É interessante notar que, nesse momento de sua obra, Freud (1905) deixa claro que a distinção entre as pulsões é dada por sua relação com as fontes somáticas e seus alvos.

Como nesse contexto (nos 'Três ensaios sobre a teoria da sexualidade') 'pulsão' está referida a 'pulsões parciais' (sexuais), o que diferenciaria uma pulsão parcial da outra seria a relação que cada uma teria com sua fonte somática. Exemplificando, se a pulsão parcial encontra sua fonte somática na boca, a pulsão se constituiria como uma pulsão oral, tendo como objetivo o prazer oral. Por outro lado, se uma pulsão parcial guarda sua fonte no aparelho excretor, ela comporia uma pulsão anal, objetivando o prazer nesta área, e assim por diante. Considerando que as pulsões parciais são sexuais, suas fontes somáticas, em relação ao atributo 'sexual' destas pulsões, tornar-se-iam zonas erógenas.

Haja vista que as pulsões parciais encontram-se ativas na constituição do indivíduo desde a sua infância, pode-se supor que não é só o adulto que transita 
por experiências sexuais, mas o infante também vivenciaria prazeres eróticos sexuais, mas não genitais - oriundos das zonas erógenas. No entanto, nesse primeiro momento o prazer seria 'autoerótico', considerando que a satisfação das pulsões parciais tem lugar no nível de suas fontes, ou seja, constituiria um 'prazer de órgão'. O objeto seria a própria fonte pulsional.

Este 'Ensaio' sobre a teoria da sexualidade trouxe importantes contribuições à teoria psicanalítica. Além dos aspectos citados acima, Freud (1905) ampliou o conceito de sexualidade humana - que passou a representar um 'desvio' em relação à função biológica da reprodução -, definindo-a como sendo em si mesma perversa $^{8}$. O qualificativo perverso aqui é colocado tanto no sentido de um desvio da norma, quanto no sentido da pluralidade de objetos - infinitos -utilizáveis como meios de satisfazer a pulsão sexual.

Com o intuito de ilustrar essa pluralidade de objetos e sua independência da pulsão, Freud (1905) cita o exemplo da escolha amorosa nos 'invertidos' (homossexuais) e bissexuais - considerados 'perversões' por se relacionarem sexualmente com a finalidade de obtenção de prazer, ao invés do objetivo de reprodução -, deduzindo que a partir desse modelo “(...) somos instruídos a afrouxar o vínculo que existe em nossos pensamentos entre a pulsão e o objeto. É provável que, de início, a pulsão sexual seja independente de seu objeto, e tampouco deve ela sua origem aos encantos deste" (Freud, 1905, p. 140). Ou seja, se a pulsão fosse dependente do seu objeto, não existiriam outras práticas de relação sexual, a não ser aquelas realizadas entre pessoas de sexo oposto, com o único fim de procriarem.

É justamente a independência da pulsão em relação ao objeto o traço diferencial em relação aos instintos dos animais, cujo objeto é pré-determinado. Em outras palavras, segundo Freud (1905), a variedade de objetos e a multiplicidade das formas de realização sexual compõem, precisamente, os fatores que vão diferenciar a sexualidade humana (pulsão sexual).

Em suma, pode-se dizer que a pulsão é um estímulo endógeno que faz uma exigência de trabalho ao psiquismo, originando-se de fontes somáticas, cujo alvo é a supressão do estado de excitação dessas fontes e o meio de se atingir seu

\footnotetext{
${ }^{8}$ Lembrando que, naquele tempo, uma sexualidade dita 'normal' teria que atender à finalidade de reprodução e manutenção da espécie, e todo comportamento sexual que fugisse a regra era considerado aberrante e perverso.
} 
objetivo passa pelos objetos que são variáveis ao infinito, tanto quanto são variáveis as formas de realização deste objetivo.

Com o objetivo de aperfeiçoar o conceito de pulsão (Trieb), Freud em 1915 lançou o artigo 'Pulsão e suas vicissitudes'. Nessa obra o metapsicólogo partiu da premissa de que a pulsão é proveniente de fontes situadas no interior do corpo e é, sobretudo, uma força constante (Konstant kraft). "Um instinto (Trieb), por outro lado, jamais atua como uma força que imprime um impacto momentâneo, mas sempre como um impacto constante" (Freud, 1915, p. 124 - grifo do autor).

Definir a pulsão como uma força que imprime um impacto constante significa compreendê-la como uma força que não cessa nunca e o máximo que se pode fazer é tentar satisfazê-la apresentando-a um objeto que possa suprir, momentaneamente, sua necessidade de descarga. No entanto, devido a sua própria natureza, ela jamais será plenamente satisfeita e persistirá demandante. Por outro lado, as forças de impacto momentâneo são aquelas provenientes de fonte exógena e podem, por isso, ser removidas através de uma ação adequada.

Sendo assim, em se tratando das pulsões, não há nada que possa ser feito para cessar esse estímulo, pois ele sempre irá insistir. Neste sentido, a pulsão obriga o sistema psíquico a alcançar certo nível de desenvolvimento para saber como evitar o desprazer característico do aumento de estimulação, sem utilizar a ‘saída' orgânica - pela via da ação motora.

Aperfeiçoando o conceito de pulsão, Freud (1915) destacou os quatros termos utilizados na montagem desse conceito: pressão, finalidade, objeto e fonte. Nenhum deles responde isoladamente pela natureza da pulsão.

Por pressão (Drang) de uma pulsão, Freud (1915) entende seu fator motor, "a quantidade de força ou a medida da exigência de trabalho que ela representa" (Freud, 1915, p. 127 - grifo nosso). Tal característica é apontada por ele como sendo a própria essência da pulsão.

Por sua vez, a finalidade ou o alvo (Ziel) de uma pulsão é sempre a satisfação, a qual só pode ser obtida eliminando o estado de estimulação na fonte. Mas, mesmo que a finalidade última de cada pulsão permaneça imutável, existem outras finalidades intermediárias mais próximas, que podem ser combinadas ou trocadas umas com as outras.

$\mathrm{Na}$ verdade, a satisfação de uma pulsão sempre será parcial, pois, se a satisfação é definida pela eliminação do estado de estimulação na fonte e, se a 
excitação pulsional é definida como uma força constante, isso significa que, em relação à pulsão, não existe possibilidade de cancelamento da estimulação. Além disso, o caminho em direção ao alvo não se dá de forma direta e imediata, mas passa pelo objeto (aquilo através do qual a pulsão procurará atingir seu objetivo).

Segundo Garcia-Roza (1995), a tese de Freud (1915) é que, não apenas o alvo da pulsão é a satisfação, mas que essa satisfação já foi obtida um dia na préhistória de cada indivíduo: “A busca da satisfação procura reeditar uma satisfação primeira, busca essa que se oferece como pretendente a ocupar o lugar da coisa, irremediavelmente perdida pelo simples fato de que nunca foi tida" (Garcia-Roza 1995, p. 91). Nessa linha, Freud (1915) anteciparia aqui um dos elementos fundamentais de sua segunda teoria pulsional, que é a repetição. Esse tema será aprofundado no próximo capítulo deste trabalho.

Continuando a descrição dos elementos pulsionais, Freud (1915) escreve que o objeto (Objekt) de uma pulsão é:

(...) aquilo em relação o qual a pulsão é capaz de atingir sua finalidade. É o que há de mais variável numa pulsão e, originalmente, não está ligado a ela, só lhe sendo destinado por ser peculiarmente adequado a tornar possível a satisfação, $\mathrm{O}$ objeto não é necessariamente algo estranho: poderá igualmente ser uma parte do próprio corpo do individuo (Freud, 1915, p. 128).

É somente por intermédio de um objeto - variável ao infinito - que a satisfação, mesmo que parcial, poderá ser obtida. Garcia-Roza (1995) aponta para o fato de esse objeto, na verdade, ser uma 'representação objeto'. Ou seja, esse objeto não é concebido como uma coisa do mundo que se oferece à percepção, mas como uma síntese de representações chamada de "representação objeto".

Finalmente, por fonte (Quelle) de uma pulsão Freud (1915) entende “o processo somático que ocorre num órgão ou parte do corpo, e cujo estímulo é representado na vida mental por uma pulsão" (Freud, 1915, p. 128). A fonte seria o próprio corpo (um órgão, ou outra parte).

Pelo menos uma questão importante surge desta definição: a questão do corpo para a psicanálise. Freud em 1915 afirma que "o estudo das fontes das pulsões está fora do âmbito da psicologia" (Freud, 1915, p. 129), sendo somente

\footnotetext{
${ }^{9}$ A 'representação objeto' é o conjunto de associações de 'imagens' - sinestésicas, motoras, táteis, olfativas, gustativas, visuais, etc. - que são formadas a partir do encontro dos sentidos com a coisa externa, mas que não representam a coisa externa em si. O contato com a coisa externa faz com que o aparato psíquico armazene traços resultantes deste encontro. São esses traços que formam essas 'imagens', as quais formam um 'complexo de imagens', que chamamos de 'representação objeto'.
} 
possível de ser reconhecida através de sua finalidade - "o conhecimento exato das fontes de uma pulsão não é invariavelmente necessário para fins de investigação psicológica; por vezes sua fonte pode ser inferida de sua finalidade" (Freud, 1915, p. 129). Isto sugere que o discurso psicanalítico sobre o corpo é bem distinto do discurso biológico - 'fora do âmbito da psicologia' - e, dessa maneira, a função fisiológica dos processos corporais, não serve como referência para a psicanálise.

Garcia-Roza (1990) observa que o corpo para a psicanálise não seria nem biológico e nem simbólico, mas um corpo que está além da linguagem e da representação. A pulsão não é nem somática e nem psíquica, nem biológica e nem simbólica, ela está na interseção destes dois campos, na fronteira. Assim também é o corpo para a psicanálise; na fronteira entre o natural biológico e o simbólico. Segundo Garcia-Roza (1990) tanto o corpo quanto a pulsão não são naturais, uma vez que a linguagem, emergindo do mundo natural como um signo arbitrário, irá produzir significados aos corpos naturais, "melhor dizendo: a partir do surgimento da linguagem, todos os objetos do mundo passaram a ser significados" (GarciaRoza, 1990, p.16).

Por 'objetos do mundo' compreende-se o homem - o ser através do qual a palavra emergiu e que ao mesmo tempo foi constituído por ela -, seus corpos, suas necessidades, e o objeto natural 'absoluto' (hipotético) responsável por ter satisfeito por 'completo' as demandas do corpo. Ou seja, a partir do momento em que estes 'objetos' são significados, eles perdem a característica de 'natural' e passam a ser 'objetos-linguagem'.

Em suma, rompida a ordem natural, as necessidades deste corpo não poderão mais ser preenchidas por objetos naturais totais, somente por objetos simbólicos - representação objeto - que nunca irão satisfazer por completo as demandas e os desejos do corpo; "o objeto absoluto foi perdido e em seu lugar surgiu a falta (não natural)" (Garcia-Roza, 1990, p.16). Podemos dizer então que a pulsão funciona como elemento de articulação entre as fontes somáticas de estímulo e o aparato psíquico (lugar da linguagem). Assim, fica clara a definição freudiana de pulsão como um conceito limite entre o psíquico e o somático. (Maldonado, 2005, p.29).

A pulsão então é uma força de pressão constante, que chega ao psiquismo a partir de uma fonte somática, tem um objeto variável ao infinito, através do qual 
realiza a finalidade de obter satisfação, mesmo que esta satisfação seja parcial (ibid., p. 24). Dessa forma, sintetiza Freud (1915):

(...) uma pulsão nos aparecerá como sendo um conceito situado na fronteira entre o mental e o somático, como o representante psíquico dos estímulos que se originam dentro do organismo e alcançam a mente, como uma medida de exigência feita à mente no sentido de trabalhar em consequência de uma ligação com o corpo (Freud, 1915, p.127).

\section{2}

\section{A primeira dualidade pulsional}

A primeira teoria pulsional descrita por Freud em 1915, em 'Pulsão e suas vicissitudes', divide a pulsão em dois grupos: as pulsões de autoconservação (pulsões do ego) e as pulsões sexuais. Esta dualidade pulsional foi abordada na conjuntura do conflito entre ego (Ich) e a sexualidade, que é o conflito implícito nas neuroses. Considerando a importância desta conjuntura para a compreensão da primeira dualidade pulsional, convém um breve desvio a fim de descrever o cenário em que este conflito - ego versus sexualidade - acontece.

Em 1906, Freud publicou um artigo a respeito de suas teses sobre o papel da sexualidade na etiologia das neuroses, refazendo o caminho que o levou a considerar a sexualidade como um dos componentes fundamentais para o conflito psíquico. Neste artigo o autor também admitiu a necessidade de rever a 'teoria da sedução, ${ }^{10}$, constatando assim que as cenas de sedução são, inúmeras vezes, fantasiosas.

Essas fantasias, muitas vezes, remetiam à infância, época em que o indivíduo ainda criança experimenta intensas sensações de prazer, e que ao longo do seu desenvolvimento psíquico vão sendo 'recalcadas'.

Não importavam, portanto, as excitações sexuais que um indivíduo tivesse experimentado em sua infância, mas antes, acima de tudo, sua reação a essas vivências - se respondera ou não a essas impressões com o "recalcamento". Viu-se que, no curso do desenvolvimento, a atividade sexual infantil era amiúde interrompida por um ato de recalcamento. Assim, o indivíduo neurótico sexualmente maduro geralmente trazia consigo, da infância, uma dose de "recalcamento sexual" que se exteriorizava ante as exigências da vida real, e as psicanálises de histéricos mostraram que seu adoecimento era consequência do conflito entre a libido e o recalcamento sexual, e que seus sintomas tinham o valor de compromissos entre as duas correntes anímicas (Freud, 1906 [1905], p. 263).

\footnotetext{
${ }^{10}$ A teoria da sedução atribui a lembranças de cenas reais de sedução o papel determinante na etiologia das psiconeuroses.
} 
Freud (1906) então observou, ao examinar a questão da histeria, que por trás do sintoma da neurose histérica encontra-se o conflito entre libido e recalcamento sexual ${ }^{11}$. Por outro lado, considerou que ambos os elementos (sexualidade e recalque) também são necessários para a saúde psíquica 'normal'.

Para resolver essa aparente contradição, Freud (1906) utilizou como parâmetro para a definição da estrutura psíquica a eficácia no processo de recalcamento da pulsão. A 'normalidade', nessa linha, pressupõe a possibilidade de as pulsões parciais serem recalcadas e direcionadas, no seu devido tempo, às zonas genitais com o fim de reprodução, ao passo que a 'perversão' deriva da impossibilidade de recalque de certas pulsões parciais e da dominância compulsiva das mesmas. A 'neurose', por sua vez, caracteriza um 'efeito colateral' do recalcamento excessivo das pulsões sexuais.

A normalidade mostrou ser fruto do recalcamento de certas pulsões parciais e certos componentes das disposições infantis, bem como da subordinação dos demais à primazia das zonas genitais a serviço da função reprodutora; as perversões correspondem a perturbações dessa síntese através do desenvolvimento preponderante e compulsivo de algumas das pulsões parciais, e a neurose remonta a um recalcamento excessivo das aspirações libidinais. Visto que quase todas as pulsões perversas da disposição infantil são comprováveis como forças formadoras de sintomas na neurose, embora se encontrem nela em estado de recalcamento, pude descrever a neurose como o "negativo" da perversão (Freud, 1906, p. 263).

Tendo em vista estes três modos de organização da libido frente aos mecanismos de defesa do ego, não restam dúvidas que o conflito que subjaz à neurose, descrito por Freud (1906), é travado entre as forças defensivas do ego, via recalcamento, e as aspirações libidinais - ou aspirações da energia sexual.

\footnotetext{
${ }^{11}$ Como a questão do sintoma neurótico comporta as ideias de 'libido' e de 'recalcamento', segundo o trecho reproduzido acima, faz-se necessário um esclarecimento sobre estes dois conceitos.

Sucintamente a libido é a energia psíquica da pulsão sexual. No artigo de 1905, Freud sugere que a libido é "uma força quantitativamente variável que poderia medir os processos e transformações ocorrentes no âmbito da excitação sexual" (Freud, 1905, p. 205).

O 'recalque' (Verdrängung), por sua vez, especificamente neste texto de 1906, é utilizado como sinônimo de defesa. No entanto, em nota de rodapé do mesmo texto, o tradutor informa que Freud em 1926 iria se referir ao recalque como uma modalidade de defesa, ou seja, uma das vicissitudes da pulsão, como já apontara em 1915.

Pode-se descrever o recalcamento como um processo defensivo contra uma ou mais representações pulsionais que possam se constituir como uma ameaça à integridade psíquica do sujeito, na medida em que o desprazer provocado por sua emergência na consciência seja maior que o prazer de satisfazê-la (Garcia-Roza, 1995). No âmbito da primeira tópica, o sistema responsável pela censura do acesso dessas representações à consciência é o sistema Préconsciente/Consciente (Pcs/Cs) e no âmbito da segunda tópica, a instância responsável pelo recalque é o ego (Ich).
} 
Essa hipótese permite a conclusão de que entre o 'normal' e o 'patológico' se interpõe uma questão quantitativa: se a quantidade de libido for suficiente para o ego dar conta de administrá-la, diminui-se a chance de o indivíduo adoecer. No entanto se a força das pulsões parciais - da libido - for excessiva ou se, inversamente, o recalque for muito severo, uma patologia perversa ou neurótica pode se instalar.

Outro exemplo esclarecedor de como o conflito pulsional acontece pode ser observado no artigo escrito em 1910 sobre as perturbações psicogênicas da visão. Neste texto, Freud (1910) explica que o prazer sexual em olhar - escoptofilia - é uma erogenização do aparelho da visão. Quando esta pulsão sexual vem a ser excessiva, provoca as defesas do ego e "o olho se converte no palco da luta entre as pulsões: o mesmo ocorre com a mão numa paralisia histérica" (Mezan, 2001, pp. 156-157). Nesse caso, segundo Renato Mezan (2001), o ego, sentindo-se ameaçado pelas exigências da sexualidade, desvia-as através do recalque para o órgão do corpo. O resultado disto é a inibição do ato de ver, resultando na cegueira histérica (ibid., p. 157).

O ego como que abandona o olho à pulsão sexual, a qual por sua vez reforça seu domínio sobre este órgão, criando um círculo vicioso do qual o indivíduo não pode sair. A energia para que o ego opere a repressão lhe é fornecida pelas pulsões de autoconservação, de onde seu outro nome 'pulsões do ego' (Mezan, 2001, p. 157).

De acordo com Mezan (2001), é com a ideia de um ego que opera com a energia das pulsões conservativas que Freud (1910) enuncia a oposição, que permanecerá essencial na sua primeira teoria pulsional, entre 'pulsões do ego' e 'pulsões sexuais'.

Seguindo seu raciocínio, as perturbações psicogênicas da visão dependem de certas ideias relacionadas com a visão (e conectadas com as pulsões sexuais) serem suprimidas da consciência (Freud, 1910, p. 223). Para que esta supressão aconteça, diz Freud (1910), é necessário que essas ideias entrem em oposição com outras ideias mais poderosas. Freud (1910) então nos esclarece que em relação a essas ideias mais poderosas “adotamos o conceito coletivo do 'ego' - um conjunto que é constituído de maneira heterogênea, em épocas diferentes - e, por esse motivo, encontram-se sob repressão" (ibid.). No entanto, esta hipótese suscita uma questão: Qual é a origem dessa oposição que provoca o recalque entre o ego e os vários grupos de ideias? O que está por trás dessas ideias antagônicas? 
Freud (1910) responde remetendo às pulsões: “A oposição entre as ideias é apenas uma expressão das lutas entre vários instintos (Trieb)" (ibid). Ou seja, o que está por trás do conflito de ideias é o conflito pulsional, são os representantes de pulsões com objetivos distintos que comparecem à arena psíquica e, deste antagonismo, emerge o sintoma.

Do ponto de vista da nossa tentativa de explicação, uma parte extremamente importante é desempenhada pela inegável oposição entre os instintos que favorecem a sexualidade, a consecução da satisfação sexual, e os demais instintos que têm por objetivo a autopreservação do indivíduo - os instintos do ego. Como disse o poeta, todos os instintos orgânicos que atuam em nossa mente podem ser classificados como 'fome' ou 'amor' (Freud, 1910, p. 223).

A novidade que este texto apresenta está no fato de o ego, um dos polos do conflito defensivo, caracterizado pelas funções de recalque, resistência e teste de realidade, receber um suporte pulsional. Com isso, o conflito subjacente às neuroses se apresenta claramente como o embate entre as pulsões sexuais e as pulsões do ego. (Maldonado, 2005).

Assim, em 1915 a primeira teoria pulsional já se apresenta de forma madura, deixando explícitas as duas grandes classes de pulsões - pulsões do ego (ou de autopreservação) e pulsões sexuais. Como visto até aqui, a pulsão sexual se manifesta como uma pressão interna e designa a sexualidade humana - não se reduzindo à genitalidade -, distinta do instinto sexual dos animais. Isto porque seu objeto não é predeterminado biologicamente e suas modalidades de satisfação são variadas.

No início as pulsões sexuais se manifestam como pulsões parciais referidas às zonas erógenas específicas para, mais tarde (possivelmente na puberdade), unificarem-se sob o primado da zona genital. Do ponto de vista econômico, Freud (1915) postula a libido como a única energia existente nas vicissitudes da pulsão sexual. Do ponto de vista dinâmico a pulsão sexual é “o objeto privilegiado do recalcamento no inconsciente" (Laplanche e Pontalis, 1982, p. 403).

As pulsões do ego (ou pulsões de autoconservação) podem ser simplificadamente entendidas como o conjunto das necessidades ligadas às funções corporais essenciais à conservação da vida do indivíduo, tendo como seu protótipo a 'fome' - são essas pulsões que, por exemplo, incitam o indivíduo a buscar comida e a se defender. O 'interesse' é a energia de investimento das pulsões do ego, assim como a libido é a energia das pulsões sexuais. 
Apesar de a pulsão do ego ter sido explicitada somente em 1910, a ideia de existir algo 'não sexual' junto ao 'sexual' já tinha sido pensada por Freud (1905) alguns anos antes. O psicanalista em 1905, num trecho dedicado ao autoerotismo, explica que "a atividade sexual apoia-se primeiramente numa das funções que servem à preservação da vida, e só depois torna-se independente delas" (Freud, 1905, p. 171 - grifo nosso).

A partir da noção de 'apoio', pode-se compreender melhor a relação primária estabelecida entre estes dois grupos pulsionais. $\mathrm{O}$ exemplo citado por Freud (1905) refere-se à experiência de amamentação do infante que, tendo acabado de saciar sua fome, cai no sono com suas faces coradas e sorriso 'beatífico', dando a perceber seu semblante de satisfação (Freud, 1905, p. 171). Essa expressão evocada por Freud (1905) muito se assemelha à expressão de satisfação sexual em épocas posteriores da vida.

Neste momento da obra de Freud (1905), o autor ainda não se referia à 'pulsão de autoconservação' propriamente dita, por isso considerava importante para a vida o apoio das pulsões sexuais às funções corporais. Em 1915, essa noção é ligeiramente modificada, apenas para inserir as pulsões conservativas no lugar das funções vitais: "Logo que surgem [as pulsões sexuais], estão ligados aos instintos da autopreservação, dos quais só gradativamente se separam; também na sua escolha objetal, seguem os caminhos indicados pelos instintos do ego" (Freud, 1915, p. 131).

Para compreender melhor em que momento, na teoria, podemos de fato falar em duas classes de pulsões, é importante retornarmos ao conceito de autoerotismo. No autoerotismo o infante busca repetir a experiência de satisfação que teve ao sugar pela primeira vez o seio materno.

Nesta primeira experiência a sensação prazerosa sentida pelo contato da boca com o seio da mãe se confunde com a necessidade de ingestão de alimento impulsionada pela fome. Assim, naquele instante, é impossível distinguir o prazer de sugar do imperativo de satisfazer a necessidade de nutrição.

Olhando esta mesma cena do ponto de vista pulsional, diríamos que há uma coincidência, ou melhor, uma indistinção entre a meta e o objeto da necessidade e do prazer - da pulsão de autoconservação e da pulsão sexual. Nesse momento a meta é satisfazer a fome e o objeto é o leite materno, para ambas as pulsões. 
Contudo, só podemos falar em pulsão sexual quando o prazer de sugar adquire independência da função de nutrição e isto pode ser observado pelo sugar autoerótico, em que a criança suga compulsivamente o polegar, não tendo a ver, diretamente, com a necessidade de se alimentar. Neste ato o que interessa é o 'sugar sensual' ou o 'prazer de órgão' - prazer na zona oral.

Em outras palavras, até o surgimento do autoerotismo as pulsões se apoiavam nas funções biológicas. A partir do autoerotismo os comportamentos pelos quais a pulsão sexual se manifesta não estão ligados aos comportamentos que atendem a uma necessidade vital. $\mathrm{O}$ autoerotismo então pode ser considerado o momento primeiro da sexualidade infantil, e o marco da diferenciação das pulsões.

\section{3}

\section{Pulsões e a formação do psiquismo}

Corroborando a importância das pulsões para a formação do psiquismo, Freud (1911) dedicou um artigo aos dois princípios do funcionamento psíquico: o princípio do prazer e o princípio da realidade. Assim, colocou em evidência a relação do ego com a realidade, e expôs o modo como as duas classes de pulsões, relacionadas a estes dois princípios, colaboram na maturação do psiquismo a fim de fazê-lo progredir para um estado de discernimento e consciência.

Freud (1911) começou por observar que o repouso, ao ser perturbado por necessidades internas, não consegue retornar ao seu estado de origem evocando, simplesmente, fragmentos de memórias (devaneios, alucinações). Torna-se então urgente a introdução de um objeto externo, extraído da realidade, para resolver o desconforto causado por esta perturbação interna real.

A introdução do objeto real em contraste com o objeto alucinado permite ao infante discernir o meio eficaz de tranquilizar a excitação. As alucinações seriam provenientes das experiências de prazer relacionadas às pulsões sexuais, e os objetos reais seriam objetos buscados através dos impulsos das pulsões de autoconservação para saciar a fome ou qualquer outra necessidade fundamental, posto que o contrário - a ausência do objeto real - ameaçaria a vida do indivíduo.

Segundo Mezan (2001), no texto de 1911 Freud utiliza o termo 'princípio de realidade' como sendo o princípio pelo qual o reconhecimento do mundo exterior 
é elevado à categoria de regulador da vida psíquica: "dele nascem a consciência, o discernimento, o pensamento e todas as atividades mentais cuja energia de funcionamento é derivada da renúncia provisória à satisfação" (Mezan, 2001, p. 157). Ou seja, ao frear a energia empregada para a satisfação, este freio, ou essa renúncia, garante que a energia que não pôde ser satisfeita armazene-se num tipo de 'reservatório'. Esse 'reservatório' de energia supre o psiquismo com energia suficiente para 'alimentar' suas imagens e produzir o pensamento.

O princípio de prazer, comprometido exclusivamente com a satisfação, seria a outra face, mais primitiva, do princípio de realidade. O princípio do prazer tem como objetivo evitar o desprazer restaurando o estado de baixa tensão identificado ao prazer. Este princípio, como não leva em conta os percalços da realidade, é tomado de urgência. Cabe ao princípio de realidade postergar o alívio do desprazer, considerando a realidade, para que o prazer possa ser alcançado com o mínimo de prejuízo ao indivíduo.

$\mathrm{Na}$ vida pré matura onde os dois gêneros de pulsões ainda se encontram imbricados, a 'realidade' - assim como os objetos 'reais' do mundo externo - não é levada em conta. O princípio do prazer então reina absoluto, pois os objetos externos necessários à vida da criança são sentidos como objetos internos. Melhor dizendo, interno e externo são percebidos como a mesma coisa, uma vez que ainda não há essa diferença, assim como o prazer e a necessidade também são indiferenciados.

No entanto, como visto anteriormente, ao mesmo tempo em que estes prazer e necessidade - começam, com o advento do autoerotismo, a se diferenciar, as pulsões sexuais ganham autonomia em relação às pulsões autoconservativas. Diferenciam-se também a meta e os objetos de ambas as pulsões. Enquanto o objeto da pulsão sexual é autoerótico, a pulsão egoica irá buscar seu objeto no mundo externo; enquanto a pulsão sexual busca o prazer de órgão, a pulsão do ego visa à satisfação de uma necessidade importante para a preservação da vida.

Dessa forma, no momento do autoerotismo, as pulsões sexuais não podem ser frustradas uma vez que seus objetos se encontram no próprio corpo e não têm como faltar. As pulsões autoconservativas, ao contrário, submetem-se ao teste de realidade já que, nesse caso, o objeto é encontrado fora do corpo e não pode ser alucinado. 
Freud (1911), contudo, adverte que seria errôneo supor que o princípio de realidade representa um adversário à altura do princípio de prazer: "Na realidade, a substituição do princípio de prazer pelo princípio de realidade não implica a deposição daquele, mas apenas sua proteção. Um prazer momentâneo, incerto quanto aos seus resultados, é abandonado, mas apenas a fim de ganhar mais tarde, ao longo do novo caminho, um prazer seguro" (Freud, 1911, p. 242).

Mezan (2001) conclui que a tendência fundamental do aparelho psíquico, em que se defrontam as duas pulsões, continua a vigorar no sentido de realizar o máximo de prazer; "só que, sendo o ser humano condenado a uma existência social, a busca pelo prazer é limitada por normas que transcendem o indivíduo e lhe impõem as restrições derivadas da cultura” (Mezan, 2001, p. 159).

Por fim, não são só as pulsões do ego, via instância egoica, que necessitam aprender a administrar suas urgências levando em conta a realidade. Em algum momento a libido também deve cair, pelo menos parcialmente, sob o controle do princípio da realidade, "pois caso contrário a probabilidade de frustração e posterior desenvolvimento de uma neurose aumentariam geometricamente" (Mezan, 2001, p. 159). Veremos o exemplo disso no 'caráter impulsivo' apresentado por Reich (1925), no capítulo seguinte.

Como visto até aqui, o conceito de 'pulsão' se revela fundamental, pois, sem as pulsões não há psiquismo, haja vista que são elas que pressionam e põem em funcionamento o aparato psíquico, incitando-o a trabalhar. Quando Freud (1905) a conceitua pela primeira vez no texto sobre os 'três ensaios', a 'pulsão' à qual se referia era a 'pulsão sexual', mais especificamente 'pulsões parciais' (sexuais).

Nessa linha, pode-se dizer que a pulsão sexual e a sexualidade humana para a psicanálise se equiparam. A sexualidade no ser humano, tal como observada por Freud (1905), diferencia-se do instinto dos animais, pois seus objetos e maneiras de atingir a satisfação são bem variados, além de não se restringir ao ato sexual propriamente dito.

A 'pulsão sexual', ou sexualidade, também se encontra na base do conflito psíquico. A libido - energia psíquica da pulsão sexual - entra em conflito com o ego - instância recalcadora -, e o incita à defesa da própria psique. No nível psíquico são as ideias, os representantes da pulsão sexual, que entram em conflito com os representantes dos 'interesses' egoicos. No nível pulsional são as pulsões sexuais que entram em conflito com as pulsões de autoconservação. 
O entendimento da primeira teoria pulsional - sobretudo o conceito de pulsão sexual e de seus efeitos tanto para uma vida psíquica 'normal', quanto para a formação das neuroses - é importante para a compreensão do ponto de partida da obra de Wilhelm Reich. Os conflitos psíquico e pulsional ocasionados pela economia da libido refletiram diretamente nos pensamentos de Reich que, como adiante se demonstra, iria abraçar essa teoria (da libido) e desenvolvê-la a fim de contribuir com o aprofundamento do ponto de vista econômico.

Nesse percurso Reich deparou-se com um conceito pouco desenvolvido pela psicanálise: a genitalidade. O autor então desdobra o conceito de libido, para apontar os fatores orgânico-energéticos das neuroses, e com isso percorrer o caminho que considerava inverso ao que estava sendo trilhado pelos psicanalistas na sua época.

\section{4}

\section{Sexualidade e Genitalidade}

A correta compreensão da primeira teoria pulsional, especialmente do conceito de pulsão sexual na teoria psicanalítica, é condição necessária para a articulação entre as teorias reichiana e freudiana. Como visto no primeiro capítulo deste trabalho, Reich se aproximou da psicanálise motivado, a princípio, por seu interesse sobre a sexualidade; "Lembrarei ao leitor que cheguei a Freud através da sexologia" (Reich, 1942, p. 83). Curiosamente foi justamente a sua total entrega à teoria da libido - levada até o seu limite (ou ao limite da própria psicanálise) -, que o fez, anos mais tarde, despedir-se deste encontro tão fértil quanto conturbado com a ciência de Freud.

De acordo com Albertini (2005), conceitualmente falando, a ligação entre a abordagem reichiana e o pensamento freudiano deve ser buscada em "um conjunto de noções relacionadas ao ponto de vista econômico - destinado a focalizar a magnitude dos fenômenos psíquicos, a sua dimensão quantitativa" (Albertini, 2005, p. 21). E conclui: "Essas concepções afinadas com o ponto de vista econômico dizem respeito, principalmente, às concepções de neurose atual e de estase da libido" (Idem, p. 21). 
Considerando as ideias reichianas acerca da neurose atual e levando em conta o conceito de estase da libido $^{12}$ (ponto de vista econômico), acompanharemos o trajeto de Reich iniciado em 1922 com um artigo que se ocupa do conceito de pulsão e libido, cotejando com seu primeiro ensaio, dedicado a Freud, sobre a função do orgasmo de 1927, até o desenvolvimento de sua própria teoria sobre a sexualidade, a saber, a Teoria do Orgasmo.

Assim, partiremos da premissa de que Reich (1922) considerou um marco as reflexões de Freud (1905) sobre a sexualidade e endossou os argumentos defendidos nos 'Três Ensaios', reiterando a crítica freudiana à confusão comum entre os conceitos de 'sexual e 'genital', assim como à imprecisa equiparação entre sexualidade e procriação. "Sexualidade é um conceito amplo, do contrário não seria possível incluir as perversões" (Reich, 1922, p. 91 - tradução nossa).

Segundo Reich (1927), Freud (1905) demonstrou que paralelamente à sexualidade genital, "encontramos tendências que nada têm a ver com as zonas genitais, tendências a que ele chama pulsões pré-genitais parciais; tais tendências buscam satisfazer-se pela excitação de certas 'zonas erógenas' (boca, anus, etc.) e podemos muito bem designá-las como sexuais, pois que desempenham um papel importante nas preliminares do ato sexual normal" (Reich, 1927, p. 33).

A ideia de 'zonas erógenas' relativiza o alcance restrito da sexualidade às zonas genitais, além de relativizar a função do sexual no ser humano. Ou seja, se antes a sexualidade era restrita àqueles que já tinham o aparelho reprodutor plenamente desenvolvido, tendo como finalidade a procriação, com a ideia de zonas erógenas existentes desde a tenra infância, a sexualidade passa a alcançar também as crianças, tornando mais difusa a sua finalidade. Dessa forma, no ser humano há também uma sexualidade erógena cuja satisfação não está na procriação, mas no autoerotismo, no prazer de órgão.

Reich (1927) compreendia perfeitamente essa ideia, no entanto, considerava que assim como a sexualidade experimentada na infância exercia um papel fundamental no desenvolvimento psicossexual do indivíduo, a genitalidade também desempenhava um papel crucial. Mais do que isso, Reich (1927)

\footnotetext{
${ }^{12}$ Segundo Albertini (2005), estase da libido é outro conceito freudiano que assume um papel central na obra de Reich. Laplanche e Pontalis assim a define: "Processo econômico que Freud supõe poder estar na origem da entrada na neurose ou na psicose: a libido que deixa de encontrar caminhos para a descarga acumula-se sobre formações intrapsíquicas; a energia assim acumulada encontrará a sua utilização na constituição dos sintomas" (Laplanche e Pontalis, 2001, p. 162).
} 
considerava que em muitos casos não havia como separar a sexualidade da genitalidade.

Esta consideração tem fundamento nos diversos casos estudados pelo autor, em que constatou que mesmo nos casos em que a neurose parecia ter sido tratada com sucesso, havia reincidência de sintomas. A sua conclusão, após a observação de centenas de casos, foi que se o paciente, mesmo tendo tratado seus traumas infantis (no caso das psiconeuroses), não tiver restabelecido a sua capacidade sexual genital, os seus sintomas neuróticos retornarão.

Isto é, o fato de haver uma distinção entre o sexual e o genital, não deveria excluir a importância da genitalidade no tratamento dos neuróticos. Para Reich (1927) esta exclusão, e a insistência em manter conceitualmente separados os dois conceitos - sexual e genital -, muito se deve à "ideia de uma vontade de tranquilizar os espíritos quanto às consequências da sua descoberta" (Reich, 1927, p. 34).

Essa é uma crítica importante em se tratando da relação de Reich com Freud. No prefácio do livro de 1927 - cujo manuscrito foi entregue pessoalmente a Freud - Reich confessa que um dos objetivos do trabalho foi "relembrar que Freud nos indicou uma solução do problema da base orgânica das neuroses e demonstrar que podemos tirar partido, teórica e praticamente, de sua descoberta por demais e por muito tempo menosprezada" (Reich, 1927, p. 29). Assim, a questão genital referida na fisiologia do orgasmo, é considerada por Reich (1927) o elemento orgânico da neurose, pouco explorada no tratamento desta patologia.

Pode-se constatar que Reich (1927) possuía um entendimento preciso da teoria freudiana, não à toa a questão da sexualidade abordada por Freud em 1905 revelou-se exaustivamente repetida ao longo deste e de outros trabalhos do autor, especialmente no seu período psicanalítico. Como adiante será exposto, foi com base nesse conceito de sexualidade e sua influência nos quadros nosográficos descritos por Freud em 1898 - neuroses atuais e psiconeuroses - que Reich passou a se questionar a respeito do papel da genitalidade stricto sensu nos quadros neuróticos.

Por 'neuroses atuais' compreendem-se as neuroses que resultam da perturbação da libido genital, ou seja, da ausência ou inadequação da satisfação sexual. Sua origem deve ser procurada no presente e não nos conflitos infantis. As psiconeuroses se opõem às neuroses atuais, principalmente quanto à sua origem, 
pois seus sintomas expressam simbolicamente os conflitos infantis. Por isso a causa dessa afecção não é encontrada numa circunstância presente. (Laplanche e Pontalis, 1982).

Freud (1898), no entanto, reconhece que é muito difícil encontrar tais patologias no seu estado puro, sendo muito mais comum a incidência em estado misto. Isto é, o psicanalista revela que em boa parte das neuroses atuais há um núcleo infantil e a psiconeurose pode apontar para uma situação presente.

Com essas definições em mente Reich (1927) veio a atuar no ambulatório psicanalítico e, através de uma simples anamnese feita em cada um de seus pacientes, colheu dados sobre a sexualidade que o deixaram apreensivo: segundo seu levantamento com 166 pacientes homens e 91 pacientes mulheres, 100\% deles apresentavam algum distúrbio relacionado ao prazer genital e/ou perturbações na capacidade de obter orgasmo. Reich (1927) então conclui haver uma correspondência muito evidente entre as neuroses e as disfunções sexuais.

Dessa forma, com base na teoria freudiana e em suas observações com os pacientes do ambulatório, o autor sugeriu que se olhe para o conflito neurótico sob outro aspecto, tendo como referência o conflito sexual e o sintoma genital. Em outras palavras Reich (1927) propôs dar ênfase à função genital e este é o gatilho para a sua teoria do orgasmo. Diz o autor:

Queremos agora provar que os conflitos sexuais no sentido restrito (inibições, recalcamento, e fragmentações das tendências genitais) são a causa do sintoma e do conflito neuróticos; (...) Ou melhor, como os conflitos sexuais se encontram ligados à perpetuação do processo neurótico, a sua eliminação desempenha, segundo pensamos, um papel crucial na terapia psicanalítica das neuroses; para nós essa terapia consiste, acima de tudo, em exercer uma influência sobre a base reacional da neurose.

Não há neurose sem perturbações da função genital; esta observação proporcionar-nos-á uma primeira prova da exatidão da nossa concepção (Reich, 1927, pp. 34, 35 - grifo do autor).

A perturbação da função genital está diretamente vinculada à manutenção do processo neurótico e leva em conta, especialmente, a face 'orgânica' do conflito. A predileção pelo fenômeno do conflito sexual em termos fisiológicos vai conduzir o autor a desenvolver um modelo do que seria uma função sexual 'normal', à qual deu o nome de 'potência orgástica'.

Por potência orgástica entendemos a capacidade no ser humano, de atingir uma satisfação de acordo com a estase libidinal do momento; mas também a capacidade de atingir frequentemente essa satisfação, permanecendo pouco sujeito às perturbações da genitalidade, que afetam por vezes o orgasmo mesmo num indivíduo relativamente são. A potência orgástica existe sob certas condições, que 
encontramos apenas no individuo capaz de satisfação e de atividade; no indivíduo neurótico, estas condições estão total ou parcialmente ausentes (Reich, 1927, p. 41).

A 'curva orgástica' - um gráfico que exprime as fases típicas do ato sexual com potência orgástica - seria uma 'ferramenta' auxiliar na medição dos avanços feitos pelos pacientes em direção à cura do sintoma neurótico. É interessante notar que por 'potência orgástica' Reich (1927) entende uma noção que extrapola os atos fisiológicos da ereção (ou prontidão orgástica) e ejaculação propriamente ditos, como mais adiante será exposto.

Apesar de se valer desses fatores fisiológicos para medir quantitativamente o avanço dos neuróticos, Reich (1927) considera que no neurótico encontra-se uma menor potência em todos os sentidos da palavra, ou seja, na neurose há um empobrecimento na capacidade do sujeito ir em direção à vida; o indivíduo inibido sexualmente é inibido socialmente, uma pessoa com menor potência sexual se encontra menos potente diante da realidade.

Reich (1927) procura validar teoricamente sua hipótese a partir da tese freudiana sobre as neuroses. Segundo o autor, Freud ensina que o homem neurótico fabrica fantasias, o que ajuda a explicar a frequente correspondência entre neurose e impotência. De acordo com Reich (1927) o interesse que criou pelo mundo imaginário impede o homem neurótico de agir na realidade, tornandoo incapaz de atividade amorosa e social.

Dessa maneira o mundo das fantasias é construído e investido com interesse contínuo porque o mundo real não satisfaz as reivindicações do princípio do prazer e porque certas exigências neuróticas e egoístas vão de encontro com normas culturais e sociais impossíveis de serem transgredidas. Na fantasia, ao contrário, o neurótico representa seus desejos como desejos satisfeitos.

Assim, inversamente ao investimento nas fantasias, o sujeito desinveste do mundo externo sua libido. "O simples fato de, no neurótico uma grande parte ou até a quase totalidade dos interesses libidinais se retirar dos objetos reais e se deslocar para representações imaginárias implica já uma menor aptidão para se adaptar à realidade e, portanto, uma menor potência em todos os sentidos da palavra" (Reich, 1927, p. 39).

Em face do exposto, pode-se afirmar que a intenção de Reich (1927) era conferir um lugar de destaque à genitalidade, sem, contudo, desprezar o conceito 
de sexualidade. Vimos que Reich tinha pleno conhecimento da diferença entre os dois conceitos, no entanto, para fins de tratamento, o autor acreditava ser importante considerar não só o aspecto psicológico do conflito neurótico, mas seu aspecto sexual-genital também.

Com isso, Reich (1927) descreve casos clínicos em que se utilizou da curva orgástica como parâmetro para medir, quantitativamente, as neuroses, e relata de forma minuciosa o comportamento sexual de seus pacientes acreditando estar contribuindo para o entendimento dos fenômenos por trás, principalmente, das neuroses atuais - neurastenia e neurose de angustia. “... a minha maneira de entender o que significa a genitalidade e, em particular, o orgasmo genital, para a teoria e a terapêutica das neuroses e dos caracteres neuróticos é, creio eu, o prolongamento direto das teorias da psicanálise e permite uma melhor aplicação da teoria das neuroses à terapêutica" (Reich, 1927, p. 26).

\section{5}

\section{Reich e a primeira teoria pulsional}

Em 1922 Reich faz um breve resumo da primeira teoria pulsional freudiana, esclarecendo, de início, a diferença entre estímulos fisiológicos e pulsão nos seguintes termos: "Devo-me voltar agora aos conceitos de pulsão e libido, como retratados pela escola freudiana (i.e. psicanalítica). Primeiro devemos diferenciar 'pulsão' de outros estímulos fisiológicos" (Reich, 1922, p. 104 - tradução nossa).

Segundo o autor, um estímulo externo pressupõe algo que vem de fora, afeta o sistema nervoso e pode ser deslocado via ação muscular. "O arco reflexo permite evitarmos o efeito de um estímulo através da atividade muscular (citando Freud, literalmente, "fuga muscular"), enviando o estímulo para a direção de onde veio” (Reich, 1922, p.104 - tradução nossa). Já um estímulo fisiológico é algo que vem de dentro do organismo, ou uma reação orgânica ao estímulo externo, e que também afeta o sistema nervoso.

A esse respeito, Reich (1922) cita o exemplo ilustrado por Freud de uma luz forte atingindo o olho em contraste com a desidratação da boca (devido à fome). Segundo ele, a primeira não é um caso de estímulo pulsional, mas a última é. Nesse caso a luz é um estímulo externo, no entanto a reação do olho a este estímulo é, por si, um estímulo fisiológico. No entanto este estímulo fisiológico - 
reação do órgão atingido por um estímulo externo - é diferente do estímulo fisiológico pulsional, que é totalmente originado no interior do organismo.

De acordo com Reich (1922), o estímulo pulsional provém do interior do núcleo orgânico, ao passo que o estímulo externo pode ser descarregado (i.e. liberado) através do esforço muscular, o que é impossível para a pulsão.

Um estímulo externo pode ser comparado a um simples impulso dinâmico. Mesmo quando ele aparenta estar continuamente ativo, ele pode, diante de um exame mais acurado, ser fracionado em impulsos individuais que, em convergência, parecem apresentar uma aparência estática. Por outro lado, a pulsão se caracteriza pela sua constante e urgente força que, no máximo, pode variar quantitativamente. Logo podemos alcançar expressões mais adequadas: "necessidade", referindo-se a estímulo pulsional, e "satisfação", à maneira pela qual a pulsão é descarregada (Reich, 1922, p. 104-105, tradução nossa).

Assim, Reich (1922) conclui que: “(...) uma pulsão é caracterizada primeiro por sua origem interna, segundo por sua incapacidade de ser descarregada pelo deslocamento muscular, e terceiro, pela constância de sua força. Esse é o ponto de vista fisiológico" (Reich, 1922, p. 105 - tradução nossa).

Garcia-Roza (1995) chama a atenção para a característica da pulsão em configurar um estímulo para o psíquico e não um estímulo psíquico, e esta é uma qualidade diferencial da pulsão. Reich (1922) não entra neste mérito, embora não ignore essa qualidade. Entretanto seu olhar apresenta um viés biológico, por isso o autor se atém aos detalhes propriamente fisiológicos do conceito.

Reich (1922) descreve que, do ponto de vista biológico, a tarefa do sistema nervoso humano se apresenta enormemente perturbada pela introdução do estímulo pulsional. Essa circunstância é percebida na reação 'eficiente' (expediency) do sistema nervoso ao ser tocado por certos estímulos fisiológicos (i.e., descarga do estímulo por meio do deslocamento muscular) (Reich, 1922, p. 105), em contraste com a reação ao ser estimulado pela pulsão. No estímulo pulsional o homem não só fracassa em evitar as fontes deste estímulo, como também é por elas atraído, pois as fontes representam o único meio de ganhar satisfação momentânea.

Em outras palavras a tarefa do sistema nervoso, via ação motora, seria reagir aos estímulos externos evitando-os. Em se tratando do estímulo pulsional a reação é outra, pois há uma aproximação com a fonte desse estímulo. Com isso, o sistema nervoso não consegue realizar a tarefa de evitar a pulsão contando exclusivamente com seus recursos, sendo necessário buscar auxílio no meio 
externo, indo ao encontro de objetos fora do mundo interno, a fim de fazer cessar o estímulo.

A eficácia (expediency) da pulsão reside no seu funcionamento como propulsor do avanço, uma vez que ela pode ocorrer apenas quando o indivíduo está em contato próximo com o mundo externo. Esse contato não pode ser alcançado através do estímulo fisiológico, mas é invariavelmente estabelecido através da pulsão, porque os objetos através dos quais a pulsão é satisfeita reside no mundo externo e nos sentimos impelidos a procurá-los fora (Reich, 1922, p. 105, tradução nossa).

Um estímulo fisiológico então teria sua 'eficácia' na 'reação' enquanto a 'eficácia' da pulsão residiria na 'propulsão do avanço' em direção ao mundo externo. Dessa forma ao mesmo tempo em que a pulsão é considerada um estímulo para o psíquico, Reich (1922) também chama a atenção para o fato de ela ser um estímulo em direção ao mundo externo, algo que impulsiona, impele o organismo a ir nessa direção.

Portanto, a partir de uma ótica biológica, Reich (1922) define a pulsão como: "um conceito limite entre o psíquico e o somático, uma representação psíquica do estímulo originando-se dentro do corpo e penetrando a psique, e uma medida das demandas de trabalho sobre a psique devido à sua relação com o corpo" (Reich, 1922, p. 105 - tradução nossa).

Dando continuidade ao texto freudiano de 1915, Reich (1922) enumera os quatro elementos que compõem a pulsão. Esses elementos são: pressão, alvo, objeto e fonte.

1. Pressão é a medida das demandas de trabalho representadas pela pulsão e ao mesmo tempo é o seu componente motor.

2. O alvo é a satisfação, a cessação do estímulo na fonte da pulsão.

3. O objeto é aquilo que promove a satisfação. Este pode ser um componente do mundo externo ou a parte do corpo de alguém.

4. A fonte é definida por Freud como 'aquele processo somático no órgão ou parte do corpo causando a estimulação da psique, como ilustrado por uma pulsão' (Reich, 1922, p. 105-106 - tradução nossa).

Quanto ao alvo, Reich (1922) esclarece que a pulsão sempre o atinge por meio de certos canais. Pode acontecer, porém, que uma pulsão seja inibida ou desviada, resultando apenas em uma satisfação parcial; dessa forma emprega-se o termo 'pulsão de alvo inibido'.

Em relação ao objeto, diz o autor, uma pulsão pode ter mais de um, e um objeto pode servir a várias pulsões. Objetos são sempre intercambiáveis, embora uma fixação permanente da pulsão em um objeto também possa ocorrer. 
Reich (1922) conclui que uma subdivisão das pulsões de acordo com o objeto ou com o objetivo é impossível devido a sua variabilidade, assim como é improvável uma subdivisão de acordo com sua pressão, a qual, embora quantitativamente diversa, encontra-se presente em todas as pulsões. Dessa forma resta apenas a divisão de acordo com a fonte e esta, revela o autor, conduz a duas pulsões primordiais que não podem ser divididas, a pulsão sexual e a pulsão de autoconservação. A primeira serve à preservação da espécie e a segunda serve à preservação do indivíduo.

Convém lembrar que Reich (1922) não se estende sobre a pulsão de autoconservação. No próprio texto de 1922, que tem parte considerável de sua narrativa dedicada à primeira teoria pulsional freudiana, há escassa menção à existência de uma pulsão primordial que serviria à preservação do indivíduo. Assim, podemos notá-la nesta caracterização e considerar que as pulsões autoconservativas e pulsões do ego representam a mesma coisa, fazendo parte do conflito psíquico se opondo à sexualidade: "O conflito mais significativo acontece entre o ego e as pulsões sexuais na medida em que o primeiro inibe o segundo. Assim nós podemos definir o conflito psíquico como uma luta entre o ego e a sexualidade (ego no sentido psicanalítico, como a mente consciente e socialmente ajustada)" (Reich, 1922, p. 112 - tradução nossa) ${ }^{13}$.

Também veremos a presença desta pulsão na obra de Reich (1933) quando o autor se refere a 'fome', deixando claro a sua adesão à ideia de haver no homem impulsos à sexualidade e à nutrição, ambos visando, em um sentido mais geral, a preservação da vida. Este assunto será mais bem explicado no próximo capítulo.

Retornando aos elementos da pulsão observa-se que, em 1927, Reich já se descola um pouco da 'letra' de Freud e permite pegar para si a teoria que tanto se engajou. Dessa forma incrementa sua compreensão a respeito dos quatro elementos da pulsão, considerando que a fonte e a pressão correspondem ao aspecto 'biofisiológico', e o alvo e o objeto, ao aspecto psicológico do conceito pulsional.

Este descolamento na verdade é uma liberdade assumida por quem tanto defendeu a causa psicanalítica, como relatou em 1952 em entrevista (Reich, 1952,

\footnotetext{
${ }^{13}$ O conflito entre sexualidade e ego, endossado pelo autor em 1922, vai sofrer uma modificação: Reich $(1925,1927$, etc.) vai deslocar o polo egoico do conflito para o superego. Este deslocamento será abordado no terceiro capítulo deste trabalho.
} 
p. 37) aos arquivos de Freud, e que se sentiu à vontade e apoiado pelo próprio Freud em seguir suas pesquisas no campo da psicanálise. Acontece que a visão de Reich de fato era compartilhada por poucos e não à toa gerou tanta controvérsia. Reich (1927) se esforçou em resgatar o viés orgânico da psicanálise e progrediu ainda mais nesse sentido na medida em que assumiu a causa da 'libido'.

\section{6}

\section{A teoria da libido sob a perspectiva de Reich}

A libido é, segundo Freud (1923a), a manifestação dinâmica da sexualidade, em outras palavras, a manifestação do movimento e das forças da sexualidade. "Libido é a manifestação da força do amor, no mesmo sentido que a fome o era do instinto autopreservativo" (Freud, 1923a, p. 271).

A teoria da libido passou por diversas transformações ao longo da obra de Freud, mas nunca perdeu o sentido de força, de movimento, de energia da pulsão sexual. A princípio, nos 'Três ensaios' de 1905, a libido estava presente em cada pulsão parcial, passível de ser deslocada de uma zona erógena a outra, resultando, em um estágio mais avançado do desenvolvimento sexual humano, na sua concentração nas zonas genitais.

Em outro momento, em 1915, a libido se fez presente no conflito entre pulsão sexual e pulsão de autoconservação, mas com a introdução do narcisismo em 1914, o embate passou a se travar entre os investimentos da libido no ego e os investimentos da libido no objeto. "A fórmula primitiva estabelecida para as neuroses de transferência consequentemente exigia ser modificada, embora não corrigida. Era melhor, em vez de falar de um conflito entre instintos sexuais e instintos do ego, falar de um conflito entre libido de objeto e libido de ego, ou, de vez que era a mesma a natureza desses instintos, conflito entre as catexias de objeto e o ego". (Freud, 1923a, p. 273).

Com o advento da segunda teoria pulsional em 1920 o conflito passa a operar entre as pulsões de vida e de morte, assumindo como sinônimos de 'pulsão de vida', 'pulsões libidinais' ou 'pulsões sexuais' (Freud, 1923a). Segundo o autor essas duas classes de pulsões estariam presentes desde a origem da vida "em misturas e fusões regulares, mas 'desfusões' também estariam sujeitas a ocorrer" 
(Freud, 1923a, p. 274). Ou seja, quando 'desfusionadas' as pulsões - de vida e morte - entrariam em oposição.

A libido para Reich (1942) assume as mesmas características explicitadas por Freud (1923a), no entanto Reich (1942) coloca o acento no seu aspecto energético (quantitativo) e menos no seu aspecto relacional (relação da libido com outra força que a opõe). Isto fica mais claro no livro de 1942, 'A função do orgasmo', onde o autor retoma o assunto sobre a função do orgasmo (descrito em 1927) resumindo e complementando o que havia iniciado até então ${ }^{14}$.

No artigo sobre o desenvolvimento da teoria do orgasmo (1942), percebe-se que a questão da energia sexual é o grande foco do autor. Para começar ele atribui à estase sexual - energia sexual represada - o núcleo energético que alimenta as neuroses.

Reich (1942) revela que os psicanalistas, na época, defendiam que toda a neurose era psiquicamente determinada, inclusive as 'atuais'. O autor contraargumenta esta hipótese sustentando que na neurose o seu conteúdo representacional, ou seja, a sua qualidade, encontra-se no psiquismo, no entanto este conteúdo por si só não é suficiente para provocar uma doença, sendo necessário haver alguma fonte de energia para alimentá-lo. Assim, Reich (1942) conclui que é a energia estásica que alimenta o núcleo neurótico, gerando o sintoma.

Reich (1942) atribui esta tese à opinião de Freud de que "toda psiconeurose se desenvolvia em torno de um "cerne neurótico atual"' (Reich, 1942, p. 84). Dessa forma, os sintomas psiconeuróticos obtém sua energia do 'cerne neurótico atual' da excitação reprimida.

Em suma, não havia dúvidas de que as psiconeuroses tinham um cerne neurótico atual (estase) e que as neuroses estásicas tinham uma superestrutura psiconeurótica. Haveria ainda necessidade de distinguir as duas? Não se trataria apenas de uma questão quantitativa? (Reich, 1942, p. 85).

Reich (1942) acredita que sim. Não importa se os sintomas de uma neurose apontam para uma neurose atual ou para uma psiconeurose, a diferença entre elas está na 'quantidade'. Quando Reich (1942) se refere à quantidade é o mesmo que

\footnotetext{
${ }^{14}$ Um diferencial entre o texto de 1927 e o de 1942 é que, no primeiro, Reich (1927) versa sobre as 'neuroses atuais', as quais ele chamava de 'neuroses estásicas', e em 1942 o autor estende a sua teoria para toda e qualquer neurose.
} 
falar em 'estase libidinal' ou 'quantum de libido' represada, e é esta 'estase libidinal' que vai alimentar as neuroses.

Como vemos, a estase libidinal é um conceito central na obra reichiana. Ela é responsável por alimentar energeticamente as neuroses e consequentemente por dificultar seu tratamento.

Nas psiconeuroses a estase seria construída a partir das frustrações experienciadas ao longo do desenvolvimento psicossexual, gerando fixações e obstaculizando a passagem da libido. Com isso, percebem-se pacientes com sintomas que remetem às fixações pré-genitais (orais, anais, etc.), especificamente onde houve um maior represamento da libido. É o caso, a título ilustrativo, de uma criança que tenha sofrido um trauma durante a amamentação, que impediu a satisfação da pulsão parcial oriunda da zona erógena oral. Com isso, uma estase libidinal é formada imprimindo em si características orais.

No caso das neuroses atuais, a frustração da libido aconteceu tardiamente, especificamente no momento presente. No entanto, isto não significa que sintomas pré-genitais, oriundos de frustrações sofridas em estágios anteriores, não possa ocorrer concomitante aos sintomas neuróticos atuais. Isto também seria possível no caso de uma psiconeurose, ou seja, um sujeito que sofreu frustrações prégenitais, também pode ter sofrido privações no momento presente, apresentando sintomas neuróticos atuais, junto com a psiconeurose. Daí a razão para Freud (1898) chamar a atenção para a ocorrência frequente de casos mistos.

É importante ressaltar que quando nos referimos às 'fases da libido', Reich e Freud têm visões um pouco diferentes. Para Freud (1905) o que caracteriza estas fases é um certo modo de organização da vida sexual, que está ligada a uma zona erógena. Para Reich estas 'fases' são uma consequência da necessidade de uma higiene precoce desempenhada pelo cuidador da criança.

Esta diferença é relevante, pois, Freud (1905) nos explica que só no último período do desenvolvimento sexual (com a organização genital pubertária), as pulsões parciais se organizariam sob o primado genital. Reich concorda que biologicamente falando, só se pode falar em orgasmo genital (com ejaculação) da puberdade em diante, quando o aparelho reprodutor estiver completo e pronto para exercer a função de procriação. No entanto, segundo o autor, a genitalidade só poderá ser experimentada a partir do momento em que o sujeito se torna capaz 
de se entregar ao fluxo de energia biológica, e descarregar completamente a excitação sexual, adquirindo assim a capacidade de auto-regulação.

A auto-regulação significa, segundo Leonardo José Jeber (2006), que um organismo saudável é um sistema regulado em si mesmo.

Esse é um conceito reichiano. Para Reich, biologicamente falando, o orgasmo é uma função auto-reguladora do organismo vivo. Ao estudar a função do orgasmo, Wilhelm Reich descobriu a fórmula da vida que se expressa em Tensão-CargaDescarga-Relaxamento. É uma fórmula que se manifesta no organismo vivo e que mostra a capacidade do organismo de se auto-regular. Para Reich, a função do orgasmo é a função vida em sua força potencial para a plena realização. Sem essa capacidade o organismo padece (Jeber, 2006, p. 28).

Como vimos, Reich (1927) faz uma diferença entre sexualidade e genitalidade. A genitalidade, em termos gerais, abarcaria então a capacidade de experimentar plenamente o orgasmo, como também a capacidade auto-reguladora do indivíduo. Ou seja, num sentido mais geral, este conceito (genitalidade) estaria, pois, diretamente relacionado com a potência orgástica.

Considerando então a face auto-reguladora da genitalidade, pode-se supor que através da auto-regulação o autor revela existir uma potência ao orgasmo desde os primeiros dias de vida do ser humano. Dessa forma fica mais fácil compreender a formação das estases sexuais; estas seriam o resultado da interferência dos cuidadores, educadores (meio externo) no circuito fisiológico da energia libidinal, que compromete a auto-regulação.

Em 1942, dissertando sobre a curva orgástica, Reich (1942) declara que adquiriu compreensão sobre as características da impotência orgástica, através da análise de muitos pacientes com distúrbios genitais. E atesta: "A impotência orgástica tem estado sempre na vanguarda da pesquisa econômico-sexual, e os seus pormenores todos ainda não são conhecidos. O seu papel na economia sexual é semelhante ao papel do complexo de Édipo na psicanálise” (Reich, 1942, p. 93).

Segundo o autor, o conceito de 'impotência orgástica' se equipara ao complexo de Édipo na psicanálise, pois este é um conceito fundamental para a economia sexual e, além disso, serve de referência para o analista compreender a diferença entre saúde e doença. Um economista sexual "sabe que o homem é a única espécie biológica que destruiu a sua própria função sexual natural e está doente em consequência disto" (Reich, 1942, p. 94).

Como dito anteriormente a impotência não é somente um problema de ereção ou de ejaculação. Estas são apenas pré-condições indispensáveis para ser 
orgasticamente potente, no entanto, pensando por um viés puramente fisiológico a "potência orgástica é a capacidade de abandonar-se, livre de quaisquer inibições, ao fluxo de energia biológica; a capacidade de descarregar completamente a excitação sexual reprimida, por meio de involuntárias e agradáveis convulsões do corpo" (Reich, 1942, p. 94). Assim, Reich (1942) enuncia categoricamente que nenhum neurótico é orgasticamente potente.

Recapitulando, a 'libido' é a 'energia orgástica', logo, a 'estase da libido' é a 'energia orgástica represada'. Essa energia represada é a fonte que alimenta as neuroses. Nas neuroses atuais (nomeadas por Reich em 1927 de neuroses estásicas) essa ligação é mais evidente, haja vista que cessando o comportamento sexual-genital que a causava - a masturbação excessiva no caso da neurastenia, ou a abstinência sexual e o coito interrompido na neurose de angústia -, o sintoma desaparece. Nas psiconeuroses esta relação não é tão clara, pois existem as fantasias que se interpõem às causas sexuais genitais, fazendo com que estas neuroses assumam um verniz puramente psíquico.

O conceito de potência orgástica então seria a capacidade que o sujeito tem de descarregar livremente a energia orgástica. Por 'livremente', Reich (1942) quer dizer sem bloqueios estásicos, em que a tensão atingiria seu ponto ótimo seguida da plena descarga, tal como mostra o primeiro gráfico abaixo:

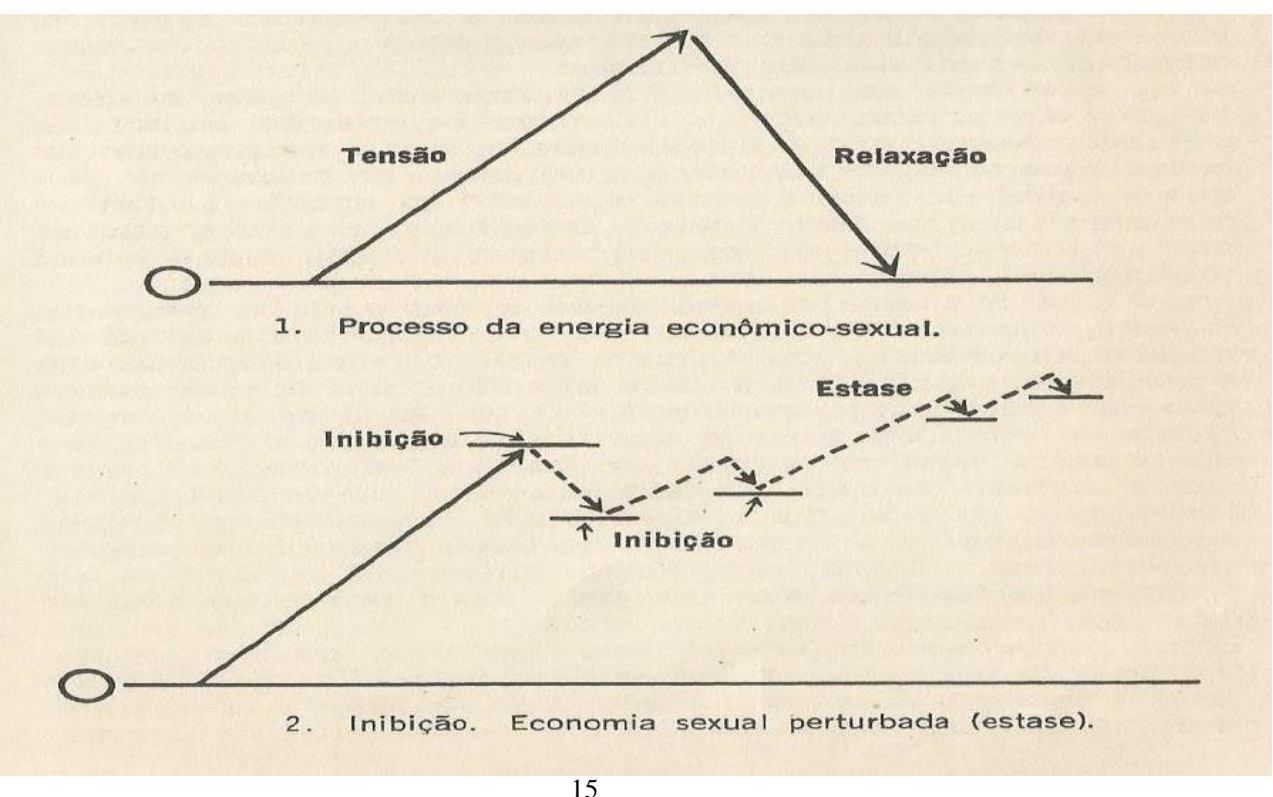

15

${ }^{15}$ Diagrama: p. 101 in ‘A Função do Orgasmo', 1942. 
O segundo gráfico mostra o processo da neurose em termos energéticos, ou seja, a formação da estase libidinal a partir das inibições, acarretando um reservatório de energia sexual, cujo acúmulo alimenta a neurose.

Assim, a 'função genital' para Reich (1942) é um conceito complexo, na medida em que não se reduz ao coito propriamente dito, mas às forças energéticas que atuam na descarga orgástica. Logo, a genitalidade também pode ser compreendida como a descarga de energia sexual.

Se eu houvesse definido a sexualidade apenas como sexualidade genital, cairia na noção pré-freudiana errada de sexualidade, e sexual equivaleria a 'genital'. Alargando o conceito de função genital com o conceito de potência orgástica, e definindo-o em termos de energia, somei uma dimensão à teoria psicanalítica de sexualidade e libido, conservando o seu arcabouço original (Reich, 1942, p. 102).

Em outras palavras, além da face psíquica e somática da pulsão sexual, o autor apresenta, com o advento da 'energia orgástica', a sua dimensão puramente energética. A psicanálise já havia apresentado a dimensão energética da pulsão sexual, ao enunciar o conceito de libido. No entanto, este conceito fora introduzido como uma energia psíquica, ou seja, seria uma representação das forças pulsionais (sexuais) no psiquismo.

Reich (1927) então se interessou pelo outro lado, isto é, se existe uma representação energética no psiquismo, qual seria o seu correspondente fisiológico? A ‘energia orgástica’ viria a seu auxílio. Assim, a energia orgástica seria o lado puramente energético-fisiológico da libido, ou melhor, da pulsão sexual.

Partindo do que foi exposto por Reich (1927), compreendemos que a estase libidinal é a fonte de energia que alimenta o conflito psíquico. Vimos também que Freud (1915) apresenta este conflito como tendo origem no antagonismo de duas ideias, que em última instância refletiria a oposição entre sexualidade e ego.

Reich (1942), valendo-se do modelo da primeira vinculação sexual da criança com os pais (conflito edípico), vai explicar como a 'estase libidinal' interfere diretamente nas consequências patológicas do conflito psíquico.

O autor então parte do princípio que o conflito edípico é o armazém histórico da experiência de que se alimenta o conteúdo da neurose: "Todas as fantasias neuróticas podem ser reduzidas à primeira vinculação sexual da criança com os pais" (Reich, 1942, p.103). 
Entretanto, Reich (1942) afirma que se as fantasias edípicas não fossem continuamente alimentadas pela estase de excitação (produzida inicialmente pelo conflito edípico), o conflito entre a criança e seus pais não poderia, por si mesmo, causar um desequilíbrio psíquico permanente (neurose). "Por isso, a estase de excitação é o fator sempre presente simultâneo da enfermidade; não contribui para o conteúdo da neurose, mas lhe fornece energia" (Reich, 1942, p. 103).

A solução encontrada pelo autor estaria na restituição da capacidade do sujeito de experimentar a plena satisfação orgástica no presente atual. "Por isso, depende do grau de descarga da energia sexual que o conflito de Édipo se torne ou não patológico. Em suma a neurose atual e a psiconeurose se sobrepõem: não podem ser concebidas como tipos separados de neuroses" (Reich, 1942, p. 103 grifo do autor).

Para ilustrar sua hipótese, Reich (1942) esboça o seguinte diagrama:

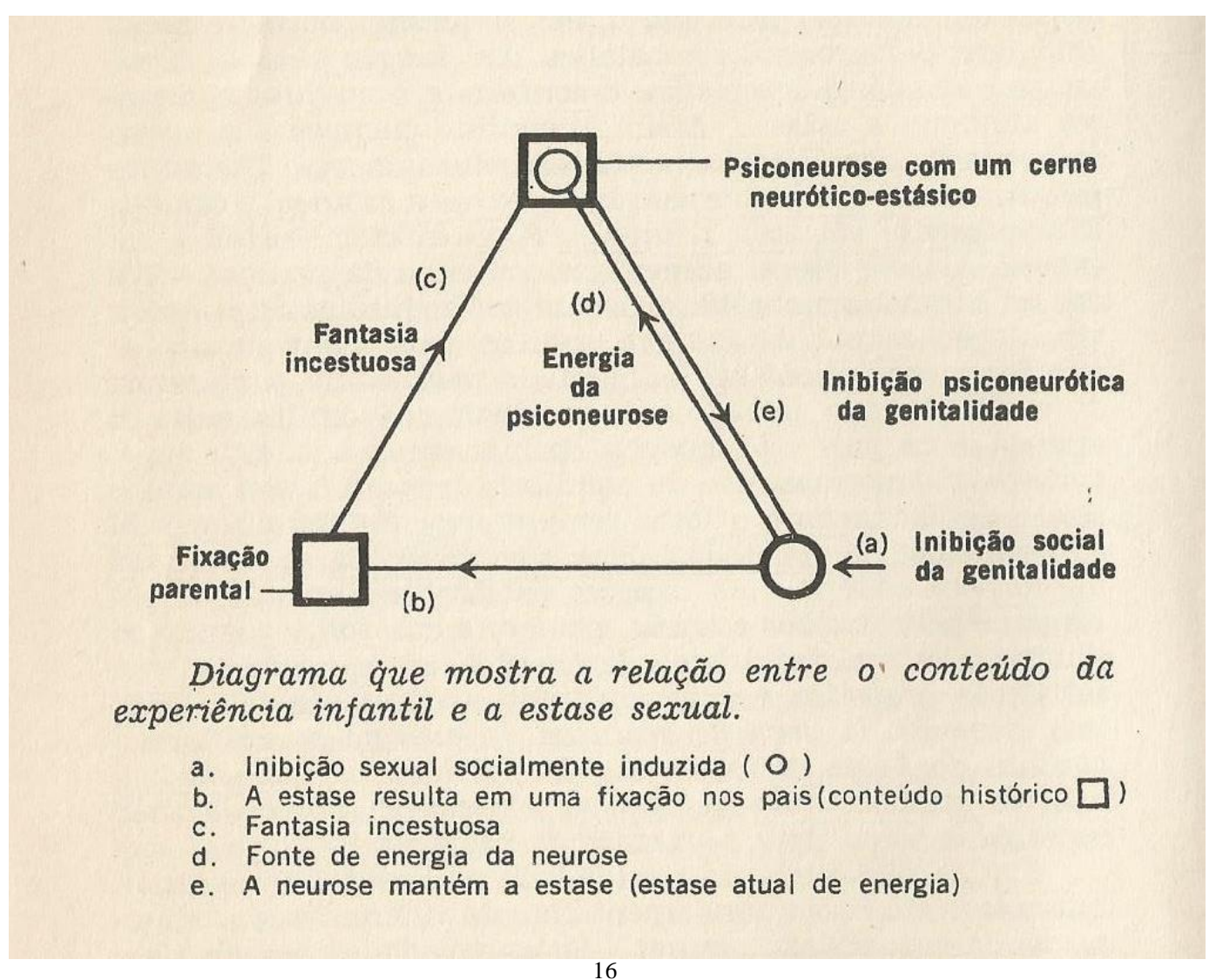

16

${ }^{16}$ Diagrama: p. 104 in 'A Função do Orgasmo', 1942. 
Dessa forma, Reich (1942) demonstra como os conteúdos psíquicos alimentam a estase e vice-versa. Por isso, levando em conta este circuito, a psiconeurose e a neurose atual (neurose estásica) ficam indiferenciadas. O que temos é um núcleo neurótico, formado por componentes históricos e estásicos, que vai depender tanto da análise dos seus conteúdos psíquicos, quanto da possibilidade de descarga da energia sexual, para deixar de produzir sintomas patológicos.

Essa ideia de que o conflito é psíquico e o que o alimenta é o seu núcleo somático, levanta uma questão importante. Como dito anteriormente, para Freud (1915) o conteúdo psíquico de uma neurose, seria construído através do conflito básico entre ideias conflitantes que remetem ao conflito entre sexualidade e ego. Com isso o psicanalista expõe que por trás dos conteúdos ideativos existem conteúdos econômicos pulsionais que atuariam junto às representações conflitantes no psiquismo, mais precisamente, no inconsciente.

A princípio Reich (1922) endossa esta hipótese, mas, em 1927 com o advento da 'Função do Orgasmo', o autor constrói um novo olhar sobre o que estaria por trás dos conflitos psíquicos. Para deixar claro o ponto de divergência entre os dois autores, vamos retornar à primeira teoria pulsional freudiana.

Freud (1915) defendia que a sexualidade está na base do conflito neurótico. Conflito este que engendrou a primeira teoria pulsional e é traduzido pelo embate entre as pulsões sexuais e autoconservativas. Em 1922 Reich concorda com Freud (1915): "nós podemos definir o conflito psíquico como uma luta entre o ego e a sexualidade (ego no sentido psicanalítico, como a mente consciente e socialmente ajustada)" (Reich, 1922, p. 112 - tradução nossa, grifo nosso).

No entanto, em 1927 Reich complementa a questão do conflito neurótico abarcando as exigências morais que dificultam a satisfação sexual. Segundo a sua compreensão do conflito, ao ego interessaria não só conservar a integridade da vida psíquica do sujeito (demanda interna), mas também atentar aos desígnios da moral, que advém do mundo exterior (demanda externa).

A recusa que todos os doentes opõem à satisfação dos seus instintos e a que se chama 'frustração interna', decorre da limitação que de fora foi imposta à vida instintiva, limitação esta que experimentaram durante a infância através dos pais ou seus substitutos. Assim, o conflito entre o eu instintivo (Trieb-Ich) e o eu moral (moralischem Ich) era primitivamente um conflito entre o eu instintual e o mundo exterior e conserva este caráter em numerosas psiconeuroses e nos psicopatas impulsivos (Reich, 1927, p. 31). 
Este trecho antecipa um assunto que vai ser desenvolvido no próximo capítulo, que é o conflito entre necessidade e mundo externo. Por ora podemos adiantar que o conflito observado entre o 'eu pulsional' e o 'eu moral' ocorre, como descreve o autor, em decorrência de um conflito anterior que seria o conflito entre as forças pulsionais e o mundo externo. Contudo, o que interessa neste momento é que Reich (1927) parece deslocar o conflito da instância egoica para a instância superegoica, haja vista que o exercício da consciência moral é uma função que extrapola as atribuições do ego, constituindo uma das funções do superego.

A importância desse deslocamento, da forma como Reich (1927) irá compreender o conflito interno e a influência deste na formulação da função do orgasmo, é enorme.

Em primeiro lugar, ao atribuir ao 'ego moral' o outro polo do conflito psíquico, Reich (1927) assinala que o conflito interno seria, no seu modo de ver, secundário. Isto se deve ao fato de o próprio 'ego moral' ser um constructo resultante da internalização de uma moral externa. Ou seja, primeiro haveria as pulsões que direcionariam sua carga energética a outrem, que as frustrariam. Posteriormente, devido a sucessivas frustrações, esta energia frustrada grava em si a 'moral' daquele que a frustrou para, em seguida, ser integrada ao psiquismo do indivíduo como um 'ego moral' que irá agir tal qual a moral externa.

Em segundo lugar, pode-se dizer que este 'ego moral' além de refletir a moral dos pais, também seria o responsável por dar continuidade ao trabalho de frear as pulsões (via recalcamento, por exemplo). Se observarmos a fluidez da libido, levando em consideração a sua interrupção pelo 'ego moral', perceberemos o mesmo movimento exposto pelo segundo gráfico acima, que ilustra a energia sexual inibida. Logo as inibições efetuadas pelo 'ego moral' também seriam responsáveis pela estase da libido.

Resumindo, para Reich (1927) o conflito básico que está por trás dos conflitos psíquicos não é entre duas pulsões que se oporiam, mas entre a pulsão sexual (ou, pelo seu viés energético-fisiológico, entre a energia orgástica) e o impedimento de sua realização pelo mundo externo: "a recusa que todos os doentes opõem à satisfação dos seus instintos e a que se chama 'frustração interna', decorre da limitação que de fora foi imposta à vida instintiva, limitação 
esta que experimentaram durante a infância através dos pais ou seus substitutos" (Reich, 1927, p. 31).

É, pois, referenciado nas ideias expostas na 'Função do Orgasmo' que Reich irá tentar dialogar com a segunda teoria pulsional de Freud. Na verdade, como veremos no próximo capítulo, as soluções apontadas por Reich a partir de suas críticas ao conceito de pulsão de morte vão contribuir ainda mais para que o autor se atenha à sua 'economia sexual'.

Reich vai compreender a pulsão de morte freudiana como um impulso biológico cujo objetivo é retornar ao inorgânico, e irá fazer um recorte deste conceito levando em conta a sua face agressiva e autodestrutiva. Devido a isso o conceito de pulsão de morte exposto no capítulo seguinte, não irá contemplar todos os desdobramentos e modificações que este conceito sofreu ao longo da obra de Freud.

Por conseguinte, tal como expresso na introdução da presente pesquisa, este trabalho não abrangerá o aspecto da pulsão de morte associada a um processo disjuntivo (Freud, 1938) e nem como uma destrutividade autônoma (Freud, 1930). Será então priorizado o texto freudiano de 1920 ('Além do princípio do prazer'), cotejado com os textos de 1923 ('O ego e o Id') e de 1924 ('O problema econômico do masoquismo'), que se articulam diretamente com as considerações feitas pelo analista corporal acerca da pulsão silenciosa. 


\section{Além do Princípio do Prazer}

\section{1}

\section{Metáforas Biológicas e Narcisismo}

Em ‘Além do Princípio do Prazer' (1920) Freud realiza um longo percurso até alcançar a nova dualidade pulsional. Passando pela biologia, pelo conceito de narcisismo, observando o fenômeno da compulsão à repetição, agressividade e considerando a possibilidade de haver um masoquismo primário, o autor chega, por fim, à construção do par pulsão de vida/ pulsão de morte.

Freud (1920) então utiliza exemplos retirados da biologia para ilustrar o seu ponto de vista também em termos orgânicos. Recorrer à biologia para dar suporte as suas ideias não é uma novidade na obra do psicanalista nem é uma condição sine qua non para a existência de sua ciência, apesar de o próprio Freud (1913) acreditar que: "depois de completar nosso trabalho psicanalítico, teremos de encontrar um ponto de contato com a biologia e será justa a nossa satisfação se constatarmos que esse contato já está assegurado num ou noutro ponto importante" (Freud, 1913, p. 184).

Pode-se tomar como exemplo a histeria, que foi elaborada psicanaliticamente por meio da experiência clínica e da construção de uma teoria, culminando com o desenvolvimento de técnicas e métodos para tratá-la, embora inexistisse correspondência orgânica no fenômeno histérico. Na mesma linha, outros fenômenos psíquicos podem ser estudados, dispensando a verificação de sua correspondência com o orgânico.

Para a psicanálise de Freud, a pulsão, mesmo sem a comprovação orgânica, é uma realidade teórica pois funciona como ferramenta clínica. Porém, isso não impediu que o metapsicólogo fosse à natureza extrair de fatos empíricos exemplos que pudessem embasar este conceito.

Assim, em 1920, Freud, ao pesquisar experimentos realizados com protozoários, identificou na teoria de E. Hering uma pulsão voltada para a vida e outra para a morte. Esta teoria aponta para a existência de dois tipos de processos 
em ação constante na substância viva, operando em direções contrárias; o primeiro sendo construtivo ou assimilatório, e o outro destrutivo e dissimilatório.

O processo construtivo, identificado com as pulsões de vida, diz respeito à união das células que se juntam para poder sobreviver enquanto 'comunidade celular', mesmo que algumas venham a morrer. O processo destrutivo pode ser identificado com a pulsão de morte se nos referirmos a esta como um 'tumor maligno' que destrói o organismo por dentro, forçando um movimento dissimilatório (Freud 1920, pp. 60, 61).

Dessa forma, poderíamos supor que as pulsões de vida, ativas em cada célula, tomam as próprias células como seu objeto, na tentativa de neutralizar os processos estabelecidos pela pulsão de morte e, com isso, preservar a vida. Dessa forma, as próprias células germinais se comportariam de forma 'narcísica' - tal como o indivíduo que retém a libido em seu ego - com a finalidade de se fortalecerem diante do processo de destruição e dissimilação perpetrado pelas forças mortíferas.

Ao sugerir que o fenômeno biológico do conjunto de células que se juntam para sobreviver em face de processos destrutivos fosse comparado a um comportamento 'narcísico', faz-se necessário algum esclarecimento acerca do conceito de narcisismo. Este conceito é um dos mais importantes na obra de Freud e um marco da passagem da primeira para a segunda teoria pulsional.

O termo narcisismo foi mencionado por Freud pela primeira vez em 1910, para explicar a escolha de objeto nos invertidos (homossexuais). Em 1911, Freud retoma novamente este termo na publicação da análise do caso Schreber e, em 1913, no capítulo III de Totem e Tabu (Laplanche e Pontalis, 1982, p. 287). Mas é no artigo de 1914, 'Para Introduzir o Narcisismo', que esse conceito surge em sua plenitude, colocando em foco os investimentos libidinais (Freud, 1914, p. 82).

Neste artigo de 1914, Freud atribui o conceito de narcisismo a Paul Näcke (1899), que designou este termo como sendo a “(...) atitude de uma pessoa que trata seu próprio corpo da mesma forma pela qual o corpo de um objeto sexual é comumente tratado - que o contempla, vale dizer, o afaga e o acaricia até" (Freud 1914, p. 81). Inspirado por tal definição, Freud (1914) sugere que algo deve ser adicionado ao autoerotismo - uma nova ação psíquica - para que o narcisismo possa se desenvolver. 
Como isso acontece? Numa época primitiva da vida do infante, a experiência com seu corpo seria a de um corpo fragmentado, sendo cada órgão do corpo, cada zona erógena, percebidas isoladamente, sem a noção de uma integração. Nesse momento o infante encontra-se numa disposição 'perversa polimorfa', pois, seu prazer estaria pulverizado pelas diversas zonas erógenas, que o provocaria com suas pulsões (parciais) e obrigá-lo-ia a satisfazê-las uma a uma. Esse momento Freud (1905) caracteriza como sendo autoerótico, uma vez que o infante, ainda não distinguindo o mundo interno do mundo externo, buscaria satisfazer essas pulsões parciais recorrendo ao próprio corpo.

Acontece que, num dado momento, a criança começa a experimentar as ausências maternas e a sentir o intervalo de tempo entre a urgência de resolver um desconforto que vem do próprio corpo e a resolução dessa urgência, que só será resolvida com os cuidados maternos apropriados. Ou seja, não há como o bebê resolver sozinho suas necessidades fundamentais de sobrevivência - mesmo com a prática autoerótica -, sendo imprescindível a presença de outra pessoa que cuida e que é externa a ele, para que isto aconteça. Aos poucos, essa experiência de espaço e tempo, vai possibilitar o infante distinguir o dentro e o fora. E o passo posterior conduzirá à seguinte elaboração: se existem um dentro e um fora, um interno e um externo, e um outro que cuida, logo, este quem é cuidado só pode ser 'eu' (ego).

$\mathrm{O}$ 'eu' aqui, ainda incipiente, seria um 'ego corporal', um ego que representaria uma unidade corporal. Assim essa 'nova ação psíquica', o ego, que é tão investido pelo outro, passa a ser também objeto de investimento libidinal do próprio infante. Dessa forma, a libido que antes era autoerótica passa a ser libido do ego, ou libido investida no ego.

O autor observou que a libido que investe no ego irá, posteriormente, investir nos objetos (libido objetal), assim como, num movimento oscilatório, irá retornar ao ego. Isto posto, Freud (1920) chega à conclusão de que "o ego é o verdadeiro e original reservatório da libido, sendo apenas desse reservatório que ela se estende para os objetos" (Freud 1920, p. 62). Dessa forma, libido e pulsões do ego parecem coincidir, já que ambas estariam 'localizadas' na mesma instância psíquica e voltariam seus investimentos para os objetos externos e para o próprio ego: 
A libido que assim se alojara no ego foi descrita como 'narcisista'. Essa libido narcisista era também, naturalmente, uma manifestação da força da pulsão sexual, no sentido analítico dessas palavras, e necessariamente tinha de ser identificada com as pulsões de autoconservação, cuja existência fora reconhecida desde o início. Assim, a oposição original entre as pulsões do ego e as pulsões sexuais mostrou-se inapropriada (Freud 1920, p. 62).

Viu-se que uma parte das pulsões do ego era libidinal e que as pulsões sexuais operavam no ego. Ou seja, ambas as pulsões - sexual e do ego - estão voltadas para a conservação da vida como finalidade última: a primeira está voltada para a conservação da espécie e a segunda, para a conservação do indivíduo. Freud (1920), então, as coloca como pertencendo ao grupo das pulsões de vida, ou Eros, o conservador de todas as coisas, oposta a pulsão de morte.

Nossas concepções, desde o início, foram dualistas e são hoje ainda mais definidamente dualistas do que antes, agora que descrevemos a oposição como se dando, não entre pulsões do ego e pulsões sexuais, mas entre pulsões de vida e pulsões de morte (Freud 1920, p. 63).

Como visto até aqui, a função da pulsão de vida seria dúplice: conservar o indivíduo através do investimento libidinal no ego (narcisismo) e conservar a espécie. A respeito desta última função, Freud (1920) a deduziu também a partir de fenômenos biológicos em especial da embriologia, donde conclui que “... a essência do processo a que a vida sexual se dirige é a coalescência - aglutinação de dois corpos celulares. Só isso é que assegura a imortalidade da substância viva nos organismos superiores" (Freud 1920, p. 66). Assim, Eros agregaria as pulsões de autoconservação e pulsões sexuais, se manifestando no narcisismo e na composição de unidades cada vez maiores através da "aglutinação de dois corpos celulares".

Contudo, voltando o olhar para a clínica, Freud (1920) observou que além das manifestações de Eros, certos pacientes apresentavam um comportamento difícil de ser explicado, especialmente quando a referência era a teoria pulsional de 1915. Este comportamento caracterizado pela compulsão à repetição não visava nem a conservação do indivíduo/espécie e nem a obtenção de prazer, sugerindo à Freud (1920) a existência de um fenômeno que estaria "além do princípio do prazer". Tal repetição fora observada sobretudo na neurose traumática, no jogo do Fort-Da e no fenômeno da transferência. 


\section{2}

\section{Compulsão à repetição}

$\mathrm{Na}$ tentativa de compreender melhor o quadro sintomático apresentado na neurose traumática, Freud (1920) conceitua três sensações que estão envolvidas na causa e na prevenção desta patologia: o susto, o medo e a angústia. Para o autor, a angústia prepara o sujeito para o susto, servindo como um alerta ao perigo que está por vir. Dessa forma, dependendo da intensidade do trauma, este pode vir a causar menos danos se o sujeito estiver atento.

Já o susto é o nome dado ao estado em que alguém fica quando entrou em perigo sem estar preparado para isso, dando-se ênfase ao fator surpresa. A diferença entre a angústia e o medo é que neste último existe um objeto definido que causa temor no sujeito. Por sua vez, na angústia o objeto é indefinido e tem como propósito preparar o sujeito para um perigo, ainda que este possa ser desconhecido (Freud 1920, p. 23).

Considerando estas três sensações dentro do quadro da neurose traumática, um fato intrigou Freud (1920): os sonhos recorrentes da situação traumática. Simplificadamente isto acontece porque o incidente traumático não pôde ser 'metabolizado' psiquicamente pelo paciente, e dessa forma a elaboração do trauma não foi possível.

Assim, os sonhos apresentados pelos pacientes que sofreram um trauma dessa magnitude, parecem servir à elaboração. Neste caso, a angústia recorrente nos sonhos prepara o sujeito para o 'susto' que não foi sentido na ocasião do ocorrido traumático e, com isso, vai 'amortecendo' o ataque violento das excitações provenientes da situação traumática.

A realização do desejo é, como sabemos, ocasionada de maneira alucinatória pelos sonhos e sob a dominância do princípio de prazer tornou-se função deles. Mas não é a serviço desse princípio que os sonhos dos pacientes que sofrem de neuroses traumáticas nos conduzem de volta (...). Podemos antes supor que aqui os sonhos estão ajudando a executar outra tarefa, a qual deve ser realizada antes que a dominância do princípio de prazer possa mesmo começar. Esses sonhos esforçamse por dominar retrospectivamente o estímulo, desenvolvendo a angústia cuja omissão constituiu a causa da neurose traumática. (Freud 1920, p. 42). 
Esta repetição intrigou o metapsicólogo, pois, como havia teorizado em 1900, os sonhos estariam a serviço do princípio do $\operatorname{prazer}^{17}$, com a finalidade de realizar desejos que não foram possíveis na vida em vigília. A constatação de que os pacientes repetem sonhos desagradáveis que só aumentam suas angústias fez o psicanalista supor que estes fenômenos não poderiam ser regidos pelo princípio do prazer, haja vista que o seu propósito (dos sonhos de angústia) não era o de evitar o desprazer - realizando desejos -, mas, pelo contrário, provocar mais ansiedade.

Acontece que o sonho repetitivo experienciado na neurose traumática não é o único fenômeno de repetição observado por Freud (1920). O psicanalista notou que podemos observar a repetição não só como consequência de um fator traumático, mas que ela também faz parte do funcionamento normal do aparelho mental do individuo. Assim, Freud (1920) propõe uma reflexão sobre a 'brincadeira das crianças' (Freud 1920, p. 25).

Observando o comportamento de uma criança, Freud (1920) constatou o seguinte: a criança jogava seu brinquedo para longe e dizia 'oooó' (fort $=$ ir embora) e, quando o apanhava, dizia 'da' (ali). O menino repetia essa ação inúmeras vezes. Segundo Freud (1920) o prazer maior se liga ao ato de reaver o objeto perdido.

$\mathrm{O}$ autor chamou essa brincadeira de jogo do 'Fort-Da' e o interpretou, relacionando-o à grande realização cultural da criança, a renúncia pulsional que efetuara ao deixar a mãe ir embora sem protestar: "Compensava-se por isso, por assim dizer, encenando ele próprio o desaparecimento e a volta dos objetos que se encontravam a seu alcance" (Freud 1920, p. 26). Assim, o prazer dessa brincadeira estaria na satisfação da pulsão de dominação (Freud 1920, p. 27), em que a criança, que inicialmente encontrava-se numa situação de ter sido deixada pela mãe contra a sua vontade, assume um papel ativo. $\mathrm{O}$ ato de afastar o objeto na brincadeira pode ser interpretado como uma forma de 'inversão' dos papéis experienciada pela criança, pois, é ela quem, agora, afasta o objeto de si e não mais o objeto que vai embora.

\footnotetext{
${ }^{17}$ O princípio do prazer seria responsável por evitar o desprazer a qualquer custo e o princípio de realidade o ajudaria com esta tarefa, levando em conta as exigências da realidade, postergando o prazer para realizá-lo em um momento mais oportuno.
} 
O importante é que a criança só foi capaz de repetir sua experiência desagradável na brincadeira porque a repetição trazia consigo uma produção de prazer de outro tipo, uma produção mais direta, manifestada num comportamento sádico: "Quando a criança passa da passividade da experiência para a atividade do jogo, transfere a experiência desagradável para um de seus companheiros de brincadeira e, dessa maneira, vinga-se num substituto" (Freud 1920, p. 28).

Em 1915, Freud já descrevia esse comportamento como uma das vicissitudes da pulsão. A 'reversão ao seu oposto' considera a passagem de uma finalidade passiva da pulsão para uma finalidade ativa. E o exemplo descrito por Freud (1915) é justamente a passagem de uma atitude 'masoquista' para uma 'sádica'.

Nesse caso, no 'Fort-Da', essa inversão é um importante instrumento para o desenvolvimento psíquico da criança, pois, ao repetir o abandono pelo objeto e o seu retorno, a criança que antes estava sujeita a esta situação, na brincadeira é ela quem assume o controle, ou seja, ela não é mais objeto do abandono, mas sujeito do seu destino. Assim, Freud (1920) conclui que: "Mesmo sob a dominância do princípio do prazer, há maneiras e meios suficientes para tornar o que em si mesmo é desagradável num tema a ser rememorado e elaborado na mente" (Freud 1920, p. 28).

Ou seja, também os sonhos traumáticos parecem executar uma importante tarefa (a de provocar angústia e de ligá-la a representações que sejam possíveis de serem elaboradas), sem a qual não é possível a sua dominância pelo princípio do prazer. Assim, Freud (1920) dá uma pista de que existe um além do princípio do prazer, onde os estímulos ainda não foram elaborados, ligados e dominados.

No 'Fort-Da', algo semelhante aos sonhos traumáticos acontece, pois, o desprazer produzido pela brincadeira, é um desprazer que conforme repetido é elaborado simbolicamente. Ao elaborar a situação angustiante, esta vai se tornando diferente (simbolizada) até não precisar mais ser repetida.

Vamos nos ater neste ponto por alguns instantes. Freud nesse texto de 1920, não faz uma divisão clara entre os exemplos que cita de 'compulsão à repetição', aliás, todos esses exemplos são nomeados como 'compulsivos'. No entanto, examinando atentamente os dois casos citados acima (neurose traumática e FortDa), percebe-se que são repetições que estão referidas além do princípio do prazer, uma vez que repetem situações não inscritas simbolicamente, e por isso 
podem ser classificadas como exemplos do que Garcia-Roza (1986) vai chamar de 'repetição do mesmo'.

Segundo Garcia-Roza (1986) 'repetição do mesmo’ e 'repetição diferencial' expressariam duas ordens distintas de repetição: “a repetição do 'mesmo' e a repetição diferencial; enquanto a primeira se aproxima da reprodução (na medida em que é estereotipada) a segunda é produtora de novidade e, portanto, fonte de transformações" (Garcia-Roza, 1986, p. 24).

A 'repetição diferencial' é produtora de novidade, pois o que se repete são conteúdos já simbolizados, ou seja, já representados. Assim, esses conteúdos representados são passíveis de deslocamento, recalque, sublimação, dentre outras 'vicissitudes'. Já a 'repetição do mesmo' se aproxima mais de uma reprodução, pois não é capaz de sofrer nenhuma vicissitude - essa repetição seria a própria natureza das pulsões e seu movimento pode ser percebido pela tentativa de se ligar a uma representação. Dessa forma, a compulsão à repetição de experiências traumáticas não atende, sob nenhum aspecto, às exigências do princípio do prazer, no entanto, mantém o seu caráter pulsional como é o caso das neuroses traumáticas (Garcia-Roza, 1986, p. 26).

Freud (1920) verificou também que a compulsão à repetição surge durante o tratamento psicanalítico dos neuróticos e que o material repetido está relacionado com alguma parte da vida sexual infantil (Édipo e seus derivados) e é atuado na transferência: "Quando as coisas atingem essa etapa, pode-se dizer que a neurose primitiva foi então substituída por outra nova, pela neurose de transferência" (Freud 1920, p. 29).

Laplanche e Pontalis (1982) resumem o conceito de transferência como um “(...) processo pelo qual os desejos inconscientes se atualizam sobre determinados objetos no quadro de um certo tipo de relação estabelecida com eles e, eminentemente, no quadro da relação analítica. Trata-se aqui de uma repetição de protótipos infantis vivida com um sentimento de atualidade acentuada" (Laplanche e Pontalis, 1982, p. 514).

Levando em consideração a diferença entre as repetições - repetição diferencial e repetição do mesmo - pode-se supor que a neurose de transferência seria uma repetição diferencial, posto que são justamente os conteúdos simbólicos de desejos inconscientes que se repetem na relação com o analista. Estes conteúdos são repetidos, ou melhor, atuados, pois o material recalcado ao mesmo 
tempo em que clama por emergir à consciência, seu ego esforça-se para mantê-los inconscientes. "As resistências do paciente originam-se do ego, e então imediatamente percebemos que a 'compulsão à repetição' 18 deve ser atribuída ao recalcado inconsciente" (Freud 1920, p. 30).

Logo, se é o recalcado que se repete, pode-se dizer então que se trata de uma repetição simbólica, corroborando a suposição de que a transferência é uma repetição diferencial.

De acordo com Mezan (2001), "Na terapia, a resistência é inconsciente, mas não pode ser concebida como se originando na pulsão: essa visa à expressão à luz do dia, jamais à frustração. Quem resiste é o ego, proibindo a emergência do que lhe causa desprazer" (Mezan, 2001, p. 254). Segundo Mezan (2001), Freud (1920), ao traçar essa distinção entre o objetivo da pulsão (se expressar) e a atuação do ego (evitar o desprazer), propõe uma questão importante: é o ego que está submetido ao princípio do prazer e não as pulsões propriamente ditas.

Dessa forma, a resistência do ego funciona sob a influência do princípio do prazer: ele (o ego) busca evitar o desprazer que seria produzido pela liberação do recalcado. $\mathrm{O}$ recalcado, no entanto, procura retornar à consciência, sob a forma de sonhos, sintomas, atuação, dentre outros.

O que Freud em 1920 observa na transferência dos neuróticos ele também observa na vida de pessoas ditas 'não neuróticas' como 'perpétua recorrência da mesma coisa'. Ele classifica isso como um traço de caráter essencial determinado por experiências infantis -, que permanece sempre o mesmo, sendo compelido a expressar-se por uma repetição das mesmas experiências (Freud, 1920, p. 32). A partir daí, Freud (1920) supôs que, talvez, as pulsões apresentassem um caráter conservador.

\section{3}

\section{O caráter conservador das pulsões}

O movimento 'natural' das pulsões — sua meta — é a satisfação completa pela via da descarga total. Isso acarretaria um estado livre de tensões. A pulsão

\footnotetext{
${ }^{18}$ Lembrando, novamente, que neste texto de 1920, Freud (1920) se refere a toda repetição como compulsiva.
} 
então pressiona a partir do interior da organização viva, para poder escoar livremente para fora desse organismo e, assim, aliviá-lo das tensões.

Os impulsos que surgem das pulsões pertencem aos processos 'livremente móveis', isso significa dizer que são as energias livres do Id - capazes de serem completamente transferidas, deslocadas e condensadas - que pressionam no sentido da descarga. O tipo de processo encontrado aí corresponde ao processo primário e o processo que opera inibindo a descarga de excitação provocada pelo processo primário é o processo secundário (Freud, 1900, p. 627).

A função do aparelho mental é, também, a de sujeitar a excitação pulsional que atinge o processo primário ao processo secundário, fazendo com que essa energia que anteriormente se encontrava livre, passe a estar 'ligada' (Laplanche e Pontalis, 2001, p. 371). De acordo com Freud (1920), é só a partir dessa 'sujeição' que é possível a dominância do princípio de prazer.

Nas palavras de Mezan (2001): "para que o princípio do prazer possa entrar em atividade, faz-se necessário a dominação prévia deste volume de excitação; o organismo obtém o controle exigido mediante a repetição" (Mezan, 2001, p. 256). Dessa forma, a repetição 'ajuda' a transformar a energia livre em energia ligada para, num segundo momento, submetê-la ao princípio do prazer. Caso a sujeição não seja possível, um distúrbio análogo a uma neurose traumática será provocado.

$\mathrm{Ou}$ seja, é necessário repetir para restaurar o controle dos estímulos mediante o desenvolvimento da angústia, cuja ausência causou o distúrbio: "Repetir é preparar o individuo para resistir melhor a traumas futuros, dotando-o da capacidade de desenvolver angústia e desta forma estar prevenido quando eles ocorrerem" (Mezan, 2001, p. 256).

Contudo, no caso da neurose de transferência, o que se repete é o recalcado e, segundo Freud (1920), 'recalcado' e 'pulsão' não são a mesma coisa. Dado que é o recalcado que compele à repetição, então: "como o predicado de ser 'pulsional' se relaciona com a compulsão à repetição?” (Freud, 1920, p. 47). A resposta é dada a partir da conclusão do caráter conservador das pulsões. Conservador no sentido de buscar repetir algo 'antigo'; voltar a um estado anteriormente conhecido.

Assim, as pulsões, ao mesmo tempo em que lutam pela descarga, lutam também para o retorno a um estado livre de tensões e de cargas; o retorno ao estado inorgânico 'primeiro' da matéria: “Se tomarmos como verdade que não 
conhece exceção o fato de tudo o que vive morrer por razões internas, torna-se mais uma vez inorgânico, seremos então compelidos a dizer que 'o objetivo de toda a vida é a morte', e, voltando o olhar para trás, que 'as coisas inanimadas existiram antes das vivas"” (Freud, 1920, p.49).

Em outras palavras, se a morte aqui é equiparada ao inorgânico, e se a vida veio depois das coisas inanimadas, podemos deduzir que a morte veio antes da vida. Assim, a vida teria na morte o seu ponto de referência de um estado primeiro, irredutível. Este estado, então, exerceria sobre as pulsões uma atração irresistível; atração para voltar ao estado livre de qualquer tensão, ao silêncio, ao retorno sobre si mesmo, sem assimilações, sem laços, sem desejos. A essa tendência, de tornar-se mais uma vez inorgânico (de repetir o estado anteriormente conhecido), Freud chama compulsão à repetição, e seu motor a 'pulsão de morte' Nas palavras do metapsicólogo:

Essa visão das pulsões nos impressiona como estranha porque nos acostumamos a ver nelas um fator impelidor no sentido da mudança e do desenvolvimento, ao passo que agora nos pedem para reconhecer nelas o exato oposto, isto é, uma expressão conservadora da substância viva (Freud 1920, p. 47).

Além da compulsão à repetição, outros fatores também contribuíram para confirmar a ocorrência da pulsão de morte como um dos polos pulsionais que regem nosso psiquismo. Teríamos uma manifestação dela, deslocada, na pulsão sádica (agressividade), por exemplo, na qual a destruição do outro seria buscada no lugar da própria morte (Gomes, 2001, p. 253). Mas, no sadismo, haveria a combinação das duas pulsões, pois a agressividade 'derivaria' da expulsão, por parte da libido, desse componente destrutivo direcionando-o contra os objetos do mundo exterior. "Percebemos que, para fins de descarga, o instinto de destruição é habitualmente colocado a serviço de Eros" (Freud, 1923, p. 54). E em 1920 Freud afirma:

(...) o próprio amor objetal nos apresenta um segundo exemplo de polaridade semelhante: a existência entre o amor (ou afeição) e o ódio (agressividade). (...) Desde o início identificamos a presença de um componente sádico na pulsão sexual (Freud, 1920, p. 64).

O componente sádico na pulsão sexual pode se tornar independente e, sob a forma de perversão, dominar toda a atividade sexual do indivíduo: "O sadismo que se tornou independente como perversão seria típico de uma desfusão, embora não conduzida a extremos" (Freud, 1923, p. 54). Também pode aparecer como 
uma pulsão parcial predominante numa das 'organizações pré-genitais’ (Freud, 1920). Porém, o importante para nós é a seguinte questão colocada por Freud: “como pode a pulsão sádica, cujo intuito é prejudicar o objeto, derivar de Eros, o conservador da vida?" (Freud, 1920, p. 64).

Freud (1920) conclui que o sadismo entra em ação a serviço da função sexual. Por exemplo, na fase oral, o sadismo visa à destruição do objeto para este ser dominado, devorado 'eroticamente' (incorporado). Na fase posterior, da primazia genital, a pulsão sádica se isola e assume, para os fins de reprodução, a função de dominar o objeto sexual até o ponto de efetivar o ato sexual (Freud 1920). Assim, como ensina o metapsicólogo: “O sadismo que for expulso do ego apontou o caminho para os componentes libidinais da pulsão sexual e que estes o seguiram para o objeto" (Freud, 1920, p. 65).

Já o masoquismo - pulsão componente complementar ao sadismo - tal como fora primeiramente apresentado em 1905 nos 'Três ensaios', seria a volta da pulsão sádica para o próprio ego do sujeito (masoquismo secundário). No entanto, em 1920, Freud retoma este conceito complementando com a ideia de que talvez exista um movimento primeiro onde do ego partiria a pulsão sádica.

Dessa forma, a volta da pulsão para o ego seria um retorno a uma fase anterior da história da pulsão, uma regressão (Freud, 1920, p. 65):

O masoquismo, a volta do instinto para o próprio ego do sujeito, constituiria, nesse caso, um retorno a uma fase anterior da história do instinto, uma regressão. A descrição anteriormente fornecida do masoquismo [em 1905] exige uma emenda por ter sido ampla demais sob um aspecto: pode haver um masoquismo primário, possibilidade que naquela época contestei (Freud, 1920, p. 65).

Em 1924, Freud aponta para o fato de que o masoquismo seria na verdade a outra parte da pulsão sádica que não se deslocaria para o exterior, permanecendo no organismo onde está ligada 'libidinalmente': “É nessa porção que temos de identificar o masoquismo original, erógeno ${ }^{19}$ " (Freud, 1924, p. 181). Ou seja, o masoquismo original é a expressão da existência de um componente sádico voltado contra o próprio sujeito, cujo sadismo expresso na agressão voltada para fora, seria secundário a este masoquismo e não o contrário.

Nota-se que o conceito de masoquismo primário influenciou uma mudança na visão de Freud sobre o ‘ódio'. A princípio Freud (1915) descreve o ódio como

\footnotetext{
${ }^{19}$ Neste caso 'erógeno' significa 'primário', tal como exposto pelo editor inglês, no volume XIX das Obras Completas (1996), p. 176, nota de rodapé.
} 
expressão da reação de desprazer provocada pelos objetos. Assim, o outro passa a ser o objeto hostil, permanecendo em íntima relação com as pulsões de conservação do ego, pois a ação de repulsa do objeto se faz necessária para poder, justamente, preservar o sujeito.

Na segunda dualidade pulsional (1920), o ódio é uma expressão sádica; é ao mesmo tempo provocado pela libido, para fora do corpo, através da expressão da agressividade, como é também o deslocamento da pulsão de morte. Ao invés do retorno, imediato, ao estado inorgânico, a pulsão de morte então seria refletida para fora na tentativa de fazer com o outro aquilo que é inevitável para si.

Em outras palavras, antes de uma pulsão sádica se virar para o exterior, existiria no próprio sujeito o protótipo da mesma. Ou seja, antes da disposição de destruir o outro, haveria uma tendência à autodestruição.

Segundo o texto 'Pulsão de morte, narcisismo negativo, função desobjetalizante', André Green (1986) esclarece que Freud (em 1923 no 'O ego e o id') deixa em aberto a questão de "qual seria a função que poderia desempenhar o papel correspondente de representante da pulsão de morte, lembrando-se que para ele é a autodestruição que é sua expressão fundamental, a heterodestruição constituindo apenas uma tentativa de alívio da tensão interna, ponto de vista contestado por muitas das teorias pós-freudianas?" (Green, 1986, p. 62). Respondendo à pergunta, Green (1986) revela que adere plenamente à hipótese de que, assim como a função sexual é o meio de se conhecer Eros, a função autodestrutiva é o meio de se conhecer a pulsão de morte. "No entanto, diferente de Freud, não creio que se deva defender a ideia de que esta função autodestrutiva se expressaria primitivamente, espontaneamente ou automaticamente" (Green, 1986, p. 62).

Contudo, Freud em 1923 afirma que:

Para a oposição entre as duas classes de instintos podemos colocar a polaridade do amor e do ódio. Não há dificuldade em encontrar um representante de Eros; mas temos de ficar gratos se pudemos achar um representante do evasivo instinto de morte no instinto de destruição, ao qual o ódio aponta o caminho (Freud, 1923, p. $55)$.

Esta é uma colocação importante, pois, como vimos, Freud em 1920 cita vários exemplos de 'compulsão à repetição' para nos mostrar a incidência da pulsão de morte (a repetição como sendo uma projeção da pulsão de morte, que incita a vida a retornar ao estado inanimado, vale dizer, a repetir um estado 
anterior da matéria). Todavia, vimos que esta compulsão à repetição pode apresentar-se de duas maneiras: como puramente pulsional (repetição do mesmo) ou repetindo conteúdos psíquicos já simbolizados e representados psiquicamente.

Dessa forma, pode-se dizer que no caso das repetições diferenciais estas se encontram no campo das pulsões de vida. Melhor dizendo, estas repetições observadas na neurose de transferência - apontam para o imbricamento entre Eros e Thânatos, sendo a ligação, a simbolização, um indício da pulsão de vida, e a repetição um indício da pulsão de morte. Dessa forma, fica difícil apontar para uma forma 'pura' da pulsão de morte.

Na neurose traumática e no Fort-Da, percebe-se que a repetição é de outra ordem, por isso identificada como uma 'repetição do mesmo' (Garcia-Roza, 1986). Neste exemplo, como o traumático ainda não foi simbolizado, o que se repete é a expressão mais legítima da pulsão de morte.

Mesmo assim, a pergunta sobre 'qual seria o meio de se conhecer a pulsão de morte no sujeito?' só será respondida com o advento do masoquismo originário (ou erógeno). Neste, como podemos deduzir a partir do enunciado por Freud em 1920, encontra-se a matriz da repetição que insiste em levar o sujeito à morte, ao autoaniquilamento. Em 1924, em um texto dedicado exclusivamente ao masoquismo, Freud (1924) vai retomar sua hipótese: "Estando-se preparado para desprezar uma pequena falta de exatidão, pode-se dizer que o instinto de morte operando no organismo - sadismo primário - é idêntico ao masoquismo" (Freud, 1924, p. 182). Voltaremos a esse tema mais adiante, quando será discutido o conceito de masoquismo em Freud e Reich.

Concluindo, em 'Além do Princípio do Prazer' (1920), o tema da repetição passa para o primeiro plano da teoria. É a repetição que vai servir de fundamento para a explicação da pulsão de morte, "algo mais primitivo, mais elementar e mais pulsional que o princípio do prazer e que se expressa pela compulsão à repetição. A repetição é a característica própria da pulsão" (Garcia-Roza 1986, p. 25). Porém, Freud (1920) também aponta, e deixa em aberto neste artigo, a ideia de um masoquismo originário, erógeno, como o caminho de se conhecer Thânatos.

Contrariamente à ideia inicial da pulsão como sendo uma força impelente dos seres vivos no sentido da mudança e da produção de diferenças, percebemos também a característica conservadora da pulsão: resistência à mudança, tendência a recobrar o equilíbrio perdido da matéria inanimada que foi perturbada pela vida. 
Assim, o objetivo da pulsão de vida, aqui, não seria evitar a morte, mas evitar que ela ocorra de forma não natural. "O que nos resta é o fato de que o organismo deseja morrer apenas do seu próprio modo" (Freud, 1920, p. 50).

Quanto à caracterização da pulsão de morte, Freud (1920) sugere que seja silenciosa, tendendo para a redução completa das tensões, ou seja, reconduzindo o ser vivo ao estado inorgânico. Voltada inicialmente para o interior e tendendo ao autoaniquilamento, a pulsão de morte seria secundariamente dirigida para o exterior, manifestando-se então sob a forma da pulsão de agressão ou de autodestruição (Freud, 1923). Sua função, ao contrário de Eros, seria desfazer o que foi construído.

O 'Além do princípio do prazer' é o marco da segunda dualidade pulsional. Os artigos posteriores que também fazem considerações à nova classe de pulsões - 'o ego e o id', o artigo sobre 'dois verbetes de enciclopédia', 'o problema econômico do masoquismo', dentre outros (para aludir àqueles artigos que serão usados, no próximo capítulo, na articulação com a teoria reichiana) - sempre retornam ao texto de 1920 como referência.

Por exemplo, em 'Dois verbetes de enciclopédia', Freud (1923) ao descrever a teoria da libido, revela que: “Os instintos eróticos e os instintos de morte estariam presentes nos seres vivos em misturas ou fusões regulares, mas 'desfusões' também estariam sujeitas a ocorrer. A vida consistiria nas manifestações do conflito ou na interação entre as duas classes de instintos (...)" (Freud, 1923, p. 274). Supõe-se assim que desde o início da vida as duas pulsões encontram-se fusionadas.

O risco é que a pulsão de vida, desfusionada, indo em direção à ligação, pode, no seu limite, se tornar excessiva. O contrário também pode acontecer, ou seja, a pulsão de morte desfusionada, assumiria uma autonomia em relação a Eros, correndo o risco de se tornar altamente destrutiva. Para que isso não aconteça, a atuação da pulsão de morte fusionada a Eros se torna indispensável.

Já no 'O ego e o id' o autor (1923) expressamente revela que irá desenvolver 'algumas sequências de pensamentos' expostos em 'Além do princípio do prazer'. Neste artigo Freud (1923) apresenta a segunda tópica, com o aparelho psíquico dividido agora em três instâncias: id, ego, e superego; derramando o inconsciente sob todas essas instâncias, esclarecendo que o inconsciente além de ser entendido pelo seu viés substantivo (dinâmico), como o 
foi na primeira tópica, também assume na segunda tópica um viés adjetivo (descritivo).

Ou seja, as três instâncias estão submetidas às forças inconscientes, sendo o id $100 \%$ inconsciente, e o ego e o superego contendo boa parte de sua estrutura também inconsciente, "e sabem os Céus que parte tão importante" (Freud, 1923, p. 31). Este artigo tão fundamental na obra freudiana (apesar de ser descrito por ele como um 'grosseiro esboço ${ }^{20}$ ) não será esmiuçado neste trabalho, mas não deixará de ser abordado mais adiante na articulação da segunda teoria pulsional com a obra de Reich.

Contudo, há uma parte deste artigo cuja exposição não pode ser adiada. Como dito poucos parágrafos acima, Freud (1923) vai trazer para este texto ideias expostas no artigo de 1920. Porém irá tratá-las sob um prisma mais psicanalítico do que biológico (Freud, 1923, p. 25). Com isso o psicanalista retoma a ideia sobre 'as duas classes de pulsões' (Freud, 1923, p. 53), relacionando-a com o aparelho psíquico da segunda tópica.

A primeira tópica, herdada da 'Interpretação dos sonhos', passará por uma revisão completa a partir da segunda teoria pulsional de 1920. Na primeira tópica, tinha-se como regra para pensar o campo freudiano, a divisão dos processos psíquicos como conscientes e inconscientes, e "tudo o que se sabia é que o inconsciente incluía o recalcado e que o conflito defensivo se dava entre pulsões sexuais e pulsões do ego" (Maldonado, 2005, p. 46).

Segundo Gabriela Maldonado (2005), dois fatores influenciaram Freud a reestruturar sua teoria sobre o aparato psíquico: $\mathrm{O}$ primeiro fator, de ordem clínica, "refere-se ao fato de que as resistências ao processo analítico são inconscientes também, apesar de derivadas do eu e servirem ao propósito de manter os recalques" (Maldonado, 2005, p. 46). E o segundo fator considera que, com a introdução do conceito de narcisismo (1914), o ego passa a ter um componente libidinal que não se reduz à finalidade autoconservativa, além de ser o 'grande reservatório' de onde partirá as pulsões.

Assim, há uma sobreposição das pulsões sexuais (libido) com as pulsões do ego, colocando-as lado a lado e não mais opostas. Esta nova condição leva

\footnotetext{
${ }^{20}$ Freud, 1923, p. 25
} 
Freud (1920) a reelaborar a teoria das pulsões, permitindo que as pulsões do ego sejam absorvidas pela pulsão de vida, no quadro da segunda teoria pulsional.

Retornando à primeira tópica, Freud (1900) considera que o recalque (censura) se localizava entre o sistema inconsciente (Ics) e o sistema préconsciente (Pcs), impedindo o acesso de certas representações à consciência. Na segunda tópica, o ego seria a instância responsável, dentre outras funções, por este recalque. No entanto, se situarmos o ego na primeira tópica, devido a sua função de recalcar, esse estaria localizado entre o sistema Ics e o Pcs.

Olhando por esse viés, na primeira tópica, não seria tão fácil reconhecer a porção inconsciente do ego, pois, este se encontraria na fronteira entre os dois sistemas (Ics e Pcs). Contudo, na segunda tópica, ao derramar o inconsciente nas três instâncias - Id, Ego, e Superego -, Freud (1923) reconhece que boa parte do ego é inconsciente e, mais do que isso, é investido pulsionalmente (como visto em 1914 na introdução ao narcisismo). Ou seja, haveria junto ao ego (o polo organizado e responsável pelo recalque e resistências) um outro polo pulsional, que vai receber o nome de Id.

O Id então passa a ser, em 1923, o grande reservatório de onde partem as pulsões que irão investir, num segundo momento, o ego e, posteriormente, em objetos externos. Assim, o conflito deixa de ser entre inconsciente e consciente e passa a ser entre o polo pulsional Id e o polo organizado e defensivo ego. Contudo, seria através dos investimentos que partem do ego que a ação de Eros pode ser percebida.

E como observar Thânatos? Teríamos 'acesso' à pulsão de morte por via da ação motora. Considerando os processos fisiológicos de anabolismo e catabolismo como dois processos associados às duas classes pulsionais "e que estariam ativos em toda partícula de substância viva" (Freud, 1923, p. 54), o autor, mais uma vez, recorre às funções orgânicas para exemplificar sua teoria. Dessa forma, para que o corpo possa expelir esta ação mortífera para fora do organismo, o aparelho muscular seria o órgão responsável por essa expulsão, desviando os impulsos destrutivos para o mundo externo. Assim, parte da pulsão de morte pareceria se expressar "como um instinto de destruição dirigido contra o mundo externo e outros organismos" (Freud, 1923, p. 54). Ou seja, na expressão destrutiva e sádica podemos reconhecer a pulsão de morte, no entanto a sua qualidade é silenciosa: 
Se não fosse pelas considerações apresentadas em Além do Princípio de Prazer, e, em última análise, pelos constituintes sádicos que se ligaram a Eros, teríamos dificuldade em apegar-nos a nosso ponto de vista dualista fundamental. Mas, visto que não podemos fugir a essa concepção, somos levados a concluir que os instintos de morte são, por sua natureza, mudos, e que o clamor da vida procede, na maior parte, de Eros (Freud, 1923, p. 59).

Um ano após a comunicação de 'O ego e o id', Freud (1924) apresenta 'O problema econômico do masoquismo'. Neste artigo, o metapsicólogo dá mais um passo em direção a provar a existência da pulsão silenciosa.

Freud (1924) então apresenta três formas de masoquismo: masoquismo moral, masoquismo feminino, e o masoquismo erógeno. Este último seria o mais elementar dos três, posicionando-se, inclusive, na base dos outros dois. É também no masoquismo erógeno que Freud (1924) reconhece a existência da pulsão de morte.

Estando-se preparado para desprezar uma pequena falta de exatidão, pode-se dizer que o instinto de morte operante no organismo - sadismo primário - é idêntico ao masoquismo. Após sua parte principal ter sido transposta para fora, para os objetos, dentro resta como um resíduo seu masoquismo erógeno propriamente dito que, por um lado, se tornou componente da libido e, por outro, ainda tem o eu (self) como seu objeto. Esse masoquismo seria assim prova e remanescente da fase de desenvolvimento em que a coalescência (tão importante para a vida) entre o instinto de morte e Eros se efetuou (Freud, 1924, p. 182).

Ao se tornar coincidente com a pulsão de morte, o masoquismo originário ganha destaque na teoria das pulsões. Assim, encontra fundamento na obra freudiana a leitura que Reich (1932) viria a realizar, considerando esses três elementos - pulsão de morte, sadismo (ou pulsão de destruição) e masoquismo originário - como equiparados.

Analisando a 'pulsão de morte' ao longo da obra de Reich, percebe-se que no início houve uma adesão a este conceito. Porém, conforme o autor desenvolvia suas teses sobre o orgasmo e a economia sexual, seu olhar foi se tornando cada vez mais influenciado pela fisiologia e focado na teoria da libido. Desse modo, a necessidade de provar a correspondência dos fenômenos psíquicos com a fisiologia, foi se tornando bastante comum nas pesquisas e teorias do autor. À vista disso, sustentava a impossibilidade de existir um impulso natural à morte, desconsiderando, por conseguinte, a existência do mesmo como uma 'pulsão'.

Contudo, ao contrário da segunda dualidade das pulsões, a primeira teoria pulsional de 1915 foi aceita pelo analista corporal, pois, como visto no capítulo anterior, tanto a pulsão sexual como a pulsão de autoconservação - a sexualidade 
e a fome - eram perfeitamente compatíveis com as teses sobre a genitalidade e a fisiologia estudadas pelo autor.

Apesar disso, mesmo aderindo ao artigo freudiano de 1915, Reich interpretava o conflito exposto pelo metapsicólogo entre a sexualidade e o ego, como sendo um conflito entre necessidade e mundo externo e não como um conflito restrito ao intrapsíquico, pelo menos não no início.

Assim, Reich observa que só se podia falar em conflito intrapsíquico, num segundo momento, quando aconteceria a internalização dos preceitos sociais e culturais e da educação imposta pelos cuidadores. O mundo externo então seria interiorizado como superego.

Como mais adiante se verá, Reich vai desdobrar seus argumentos contra uma pulsão inata que objetiva a morte, partindo da discordância entre a tese de um masoquismo originário inerente ao ser humano e a tese de uma compulsão à repetição não sujeitada ao princípio do prazer. Para este autor, Thânatos é secundário e não 'primário'.

\section{4}

\section{Reich e a Pulsão de Morte}

O texto freudiano de 1920 é fundamental para termos em mente o início do desenvolvimento da segunda teoria pulsional e mais precisamente como Freud construiu o conceito de pulsão de morte. Ou seja, quais foram os fenômenos clínicos observados pelo autor que o fizeram deduzir a existência da pulsão silenciosa? É, pois, com as questões levantadas neste artigo e desdobradas em artigos posteriores, que Reich irá dialogar e tentar provar o seu ponto de vista de que não existe um 'além do princípio do prazer'.

O conceito de pulsão de morte é um marco da divisão entre as teorias de Freud e Reich. Na verdade, a pulsão de morte em si, ou seja, o fato de Reich não concordar com este conceito, não seria por si só razão para haver um racha entre os dois autores, até porque nem todo psicanalista concorda ou concordou com este conceito.

A questão é que a pulsão de morte impôs um obstáculo ao caminho que Wilhelm Reich vinha trilhando. Sua ideia era provar a psicanálise como uma ciência natural, capaz de ser comprovada empiricamente, com estudos 
quantitativos e qualitativos de sua energia pulsional e sua correspondência com o orgânico. Naquela época, até onde alcançava a sua compreensão, Reich não conseguia entender de que modo uma força que objetivava a morte pudesse existir na natureza. Esta ideia era completamente incompatível com suas observações clínicas e concepções teóricas.

Em 1925, explicando o 'Caráter Impulsivo’ (ou pulsional), Reich dialoga com Freud de 'O ego e o id', defendendo a tese de que a pulsão de destruição/autodestruição poderia ser originada da frustração (sentida como excessiva) exercida sobre o ego prazer, que não havia experimentado nenhuma espécie de frustração anterior. Esta experiência levada ao extremo ocasiona um superego isolado, gerando no sujeito uma ambivalência e um masoquismo radicais que fariam qualquer analista supor a existência de um ódio mortífero intrínseco à natureza do ser humano.

Em 1927 Reich soma outro ingrediente (estase libidinal) ao texto de 1925 e declara que 'a pulsão de destruição depende da estase libidinal' (Reich, 1927, p. 209), deixando claro o papel do superego na repressão da pulsão sexual. Se Reich (1922) havia deixado alguma dúvida sobre a importância do superego no conflito psíquico, a partir do texto de 1925 e no capítulo VII da 'Função do orgasmo' de 1927, o autor vai esclarecer esta dúvida.

Curiosamente, como será visto a seguir, no capítulo VII do artigo de 1927, Reich dá a entender que aceitava a pulsão de morte freudiana. No entanto, ao longo de sua exposição, ao concluir que a estase libidinal é o reservatório de energia que alimenta as neuroses e os impulsos destrutivos, percebe-se que o que ele considerava como pulsão de morte neste texto, não é exatamente o mesmo conceito exposto por Freud (1920).

Em 1932 Reich publica o 'caráter masoquista'. Este artigo "representa o rompimento clínico de Wilhelm Reich com a teoria freudiana da pulsão de morte" (Reich, 1932-1933, p. 215 - nota do editor). Reich (1932), neste texto, rebate a pulsão de morte argumentando contra o que ele considera ser o principal argumento de Freud (1924) que justificaria a existência dessa pulsão: o masoquismo originário. Além disso, o autor expõe sua tese a respeito da compulsão à repetição considerando-a "um fenômeno real, porém algo que pode e deve ser formulado dentro do princípio do prazer" (Rego, 2005, p. 35 - grifo nosso). 
Continuando com sua linha de raciocínio, Reich em 1933 vai defender que o conflito responsável pelas neuroses então não seria intrapsíquico - entre pulsões opostas - como sugere Freud (1920), pelo menos não no início. O que ocorre é um conflito inicial entre necessidade e mundo externo e somente numa etapa posterior é que este conflito será internalizado.

Para concluir, qualquer menção à pulsão de morte vai sendo deixada de lado por Reich principalmente após seu desligamento com a IPA em 1934. No entanto, em 1952, na ocasião de uma entrevista concedida aos arquivos de Freud, Reich confessou:

Hoje sei que ele [Freud] pressentia algo no organismo humano que era mortal. Mas ele pensava em termos de instinto. Assim chegou ao termo 'instinto de morte'. Isso estava errado. 'Morte' estava certo, 'instinto' estava errado. Porque não se trata de nada que o organismo deseje. É algo que acontece no organismo. Logo, não é um instinto (Reich, 1952, p. 90).

Assim, mesmo considerando tardiamente o insight de Freud sobre a existência de "algo no organismo humano que era mortal", para Reich (1952) este 'algo' nunca poderá ser uma 'pulsão', pois, segundo o autor, seria biologicamente impossível haver um impulso inerente ao ser vivo que busque e deseje a morte.

\section{5}

\section{O Caráter Pulsional}

Reich em 1925 desenvolveu uma hipótese que iria servir como base para seus argumentos posteriores acerca da pulsão de destruição. A tese a respeito do 'Caráter Impulsivo' ${ }^{21}$ versa sobre um tipo especial de patologia do ego (identificada com as patologias limítrofes), na qual o indivíduo se encontra à mercê de suas pulsões. Ou seja, para usarmos a classificação descrita por GarciaRoza (1986), os fenômenos que servem para diagnosticar um caráter como impulsivo, são comandados pela compulsão à repetição do tipo 'repetição do mesmo', da mesma coisa, onde o sujeito mal consegue se entregar à associação livre e, muito menos, elaborar qualquer conteúdo psíquico a respeito de sua doença. Refém da pulsão, o paciente só consegue atuar o seu drama na análise.

\footnotetext{
${ }^{21}$ Vale lembrar que tanto impulso quanto pulsão são termos que servem para traduzir o termo original Trieb. Título original: 'Der Triebhafte Charakter'.
} 
O que mais chama a atenção é que esta 'repetição' não é um sintoma isolado, ou um traço de uma neurose, é algo que recai sobre toda a constituição do sujeito, seu caráter. Assim, o caráter impulsivo é uma forma específica de caráter neurótico.

Em 1925, antes de introduzir o caráter impulsivo, Reich fará um breve resumo da distinção observada por ele entre um 'sintoma neurótico' e um 'caráter neurótico'. O autor considera sintoma e caráter neuróticos como expressões de uma fixação no âmbito do desenvolvimento psicossexual. A diferença entre eles aparece na abrangência:

O sintoma neurótico localizado corresponde diretamente às áreas parciais da personalidade que ficaram 'fixadas' num ou noutro estágio, ao passo que o caráter neurótico é sempre uma expressão da atitude total correspondente à fixação. Assim, uma fixação (e o conflito dela resultante) sempre apresentará ao mesmo tempo dois modos de expressão: primeiro, o sintoma neurótico que lhe corresponde particularmente (por exemplo, o vômito histérico como expressão de fixação oralgenital) e, segundo, o caráter neurótico, que corresponde ao distúrbio evocado na personalidade como um todo pela fixação parcial (Reich, 1925, p. 12).

O 'caráter' então corresponderia às alterações totais que tal fixação provoca na personalidade, não sendo possível encontrá-las em apenas um comportamento específico. Neste mesmo texto Reich (1925) completa:

Para ser coerentes, devemos admitir portanto que até os distúrbios insignificantes em si não deixam de afetar o restante da personalidade. Desse modo, todo sintoma neurótico se fundamenta em um caráter neurótico e podemos falar num caráter histérico ou compulsivo (e possivelmente esquizoide) encimado por seus sintomas como uma montanha por seu pico. Tanto o caráter neurótico como o sintoma neurótico têm suas qualidades específicas determinadas pela fase em que o desenvolvimento foi interrompido (Reich, 1925, p. 12).

Considerando o caráter como uma expressão ampla das fixações parciais na personalidade, Reich (1925) abriu a possibilidade de pensá-lo como a base do sintoma neurótico, o que leva a considerar a neurose sintomática como sendo sempre, em termos mais abrangentes, uma neurose de caráter (Silva, 2001, pp. 75, 76).

Dito isso, Reich (1925) explicou então o caráter impulsivo tendo como pano de fundo a sua experiência na Policlínica Psicanalítica, as discussões do Seminário de Técnica Psicanalítica, o novo conjunto de conceitos extraídos de 'O ego e o id' (Freud, 1923) e a sua recente teoria do orgasmo (Silva, 2001, p. 64).

Este caráter se chama impulsivo não à toa, ele representa uma forma específica de caráter neurótico dominado pelas pulsões. Essa dominação se deve 
ao fato de, ao longo do desenvolvimento do ego, ao invés de haver uma integração do superego com as outras instâncias (ego e id), este se desenvolve isolado. Isso acontece porque a inibição da pulsão se deu de forma defeituosa, geralmente muito tardia e traumática.

Explicando de forma sucinta, Reich (1925) revela que utiliza a expressão 'caráter impulsivo' "quando a personalidade é dominada por ações e padrões comportamentais com respeito ao mundo externo que são ditados pela compulsão à repetição" (Reich, 1925, p. 6). Esta compulsão é manifesta sob a forma de um padrão de comportamento em que o indivíduo é inundado pelos seus impulsos e não encontra meios de freá-los. Assim, as ações e experiências impulsivas são "primitivas e permeadas de impulsos masoquistas, sádicos, anais, orais e similares, todos sem disfarces (Reich, 1925, p. 7) ${ }^{22}$ ”.

Em outras patologias neuróticas não impulsivas, o recalque seria uma forma de defesa contra a inundação das pulsões. No caso do caráter impulsivo, o autor sugere que esta defesa (contra a inundação das pulsões) se dá de forma diferente do que em outras neuroses e "esta será a questão central da discussão (Reich, 1925 , p. 5)"'.

Como será visto adiante, o caráter impulsivo aponta para uma estrutura psíquica um pouco diferente da dos neuróticos, pois o superego que deveria ser integrado ao ego e ao id, se apresenta isolado. Esse isolamento impossibilita o estabelecimento do recalque. Uma vez que o recalque serve para deter no inconsciente as pulsões sexuais 'recalcadas', percebe-se que no caso do paciente impulsivo isto não ocorre; as pulsões do id escoam sem barreiras (não estão ligadas, encontram-se 'sem disfarces'). Neste caso é o superego isolado que atuaria como a pulsão sexual recalcada, isto é, pressionando para ser satisfeito, mas com uma diferença: sua satisfação se dá, pois, pela busca de punição que acompanha a atuação dos impulsos do id.

Sendo assim, a questão que se coloca a seguir é: como ocorre o isolamento do superego? Para responder à pergunta, Reich (1925) voltou sua atenção ao

\footnotetext{
${ }^{22}$ Segundo Reich (1925) "tendências primitivas sem disfarces" são colocadas em oposição às tendências "sujeitas a um vasto processamento secundário e disfarçadas" (Reich, 1925, p. 6).
} 
desenvolvimento psicossexual e expôs, primeiramente, a maneira mais 'comum' de funcionamento da atividade psíquica ${ }^{23}$.

Assim, considerando esta atividade psíquica 'comum', observa-se que as chamadas defesas primitivas atuariam de forma negativa em relação à libido, ou seja, atuariam criando barreiras e frustrando a livre satisfação libidinal. Estas frustrações seriam criadas, a princípio, pelo ambiente, ou melhor, pelos pais da criança, seus 'educadores'.

Esses educadores funcionam não apenas como objeto das primeiras demandas pulsionais, não apenas como objetos que proporcionam certo grau de satisfação pulsional - como é o caso particular do período de amamentação; eles também exercem o papel crítico na frustração da pulsão, impondo assim as primeiras e mais significativas restrições (Reich, 1925, pp. 17, 18).

De acordo com João Rodrigo Silva (2001), as pulsões infantis seriam então parcialmente gratificadas e parcialmente reprimidas pelos pais, numa medida e forma tais, que essa repressão seja suportada pela criança por amor aos pais (aquele, em particular, responsável pela interdição) (Silva, 2001, p. 65). Por exemplo, 'No começo ela [a criança] acostuma-se com o asseio 'pelo amor' da mãe" (Reich, 1925, p. 19).

Num segundo momento, após a 'passagem' pelo complexo de Édipo e com um ego mais estruturado, essas repressões, ou frustrações da satisfação libidinal associadas à figura parental, seriam assimiladas como superego no psiquismo - "a formação do superego começa com a frustração em geral e se conclui essencialmente com a frustração do desejo edipiano incestuoso" (Reich, 1925, p. 21) -, proporcionando, desse modo, um desenvolvimento egoico integrado e dirigido à realidade (Silva, 2001, p. 65).

$\mathrm{Na}$ verdade a frustração é encontrada em cada estágio do desenvolvimento da libido, o que nos possibilita situar o início da formação do superego em uma época imediatamente posterior ao nascimento. Mesmo acostumar o bebê a horários fixos de refeição é uma frustração de sua necessidade incessante de sugar. Para ir um passo além, a primeiríssima frustração é o próprio nascimento, na medida em que o prazer da vida intrauterina chega então ao final (devido à falta de estímulos) (Reich, 1925, p. 21).

Essa assimilação das repressões acontece através das identificações que a criança tem com seu cuidador: "quando a criança renunciou a uma forma

\footnotetext{
${ }^{23}$ Qualquer semelhança com a segunda tópica freudiana e o advento do superego descrito por Freud (1923) não é mera coincidência. Reich (1925), completamente inserido no campo psicanalítico, dialoga abertamente com o metapsicólogo e cita sua teoria (de Freud) a fim de compor suas próprias ideias (de Reich) e desenvolver a sua hipótese.
} 
específica de prazer pelo amor da mãe, ela assimilou uma exigência da mãe, e estamos diante de um caso de identificação primitiva, embora ainda haja muito apego ao objeto envolvido, sem o que a identificação seria intolerável” (Reich, 1925, p. 19).

Resumindo, segundo Reich (1925) em cada etapa do desenvolvimento psicossexual, com a supressão parcial da satisfação libidinal, o ego vai se fortalecendo, tornado-se capaz de suportar frustrações. Junto com o fortalecimento do ego, o superego também vai se formando (desde o nascimento), até ser ‘concluído' com a frustração do desejo edipiano incestuoso e assimilado junto às outras instâncias na estrutura psíquica. Este superego é formado, sobretudo, pela identificação com o pai cuidador.

Podemos dizer que, até agora, Reich (1925) não nos apresentou nenhuma novidade se compararmos a sua explicação da formação do superego com a teoria freudiana de 1923.

(...) a instalação do superego pode ser classificada como exemplo bem-sucedido de identificação com a instância parental. $\mathrm{O}$ fato que fala decisivamente a favor desse ponto de vista é que essa nova criação de uma instância superior dentro do ego está muito intimamente ligada ao destino do complexo de Édipo, de modo que o superego surge como o herdeiro dessa vinculação afetiva tão importante para a infância. Abandonando o complexo de Édipo, uma criança deve, conforme podemos ver, renunciar às intensas catexias objetais que depositou em seus pais, e é como compensação por essa perda de objetos que existe uma intensificação tão grande das identificações com seus pais, as quais provavelmente há muito estiveram presentes em seu ego (Freud, 1933[1932], p. 69).

Assim como Freud (1923) ensina, Reich (1925) repete: o superego é o herdeiro do complexo de Édipo, tendo como base de sua formação a influência predominante da figura parental cuja ambivalência foi mais forte, ou seja, o genitor mais dominante na negação das pulsões (Reich, 1925, p. 34).

No entanto, é a partir dessa conformidade com a teoria de Freud (1923) que a originalidade do conceito de 'caráter impulsivo' emerge. A principal questão deste caráter gira em torno do isolamento do superego. Reich (1925) explica que no caráter impulsivo as gratificações e repressões feitas à libido em cada fase do desenvolvimento psicossexual, não foram efetuadas corretamente; muito provavelmente, houve mais gratificações do que frustrações das pulsões.

Segundo Reich (1925), isto se deve à possibilidade do "comportamento das figuras parentais, que deveria servir de modelo para a formação do ideal do ego da criança, (...) não estar voltado contra a impulsividade original, mas, ao contrário, 
(...) estar completamente de acordo com ela" (Reich, 1925, p. 84). Dessa forma, a pulsão teria seguido muito tempo sem contenção, fortalecendo as demandas pulsionais do ego primitivo (ego prazer) e impedindo o desenvolvimento da tolerância à frustração.

Em outras palavras, a permissividade com que o ambiente (pais, educadores, etc.) tratou a satisfação pulsional, condescendendo com a sua manifestação de forma ampla e desinibida, fortaleceu o ego prazer. Essa circunstância dificultou a assimilação, por parte do ego, das frustrações experienciadas posteriormente, haja vista que na mesma proporção que a intensidade pulsional vai ao encontro de seu objeto amoroso, também se volta contra as frustrações que dele provém.

Considerando essa situação, se a frustração ocorre de forma traumática, numa intensidade e maneira que confronta diretamente o ego prazer, este vai, sem dúvida, colocá-la (a frustração) para escanteio ao invés de assimilá-la. Dessa forma o ego se torna intolerante à frustração e constrói obstáculos à constituição gradual de um superego.

Frente à repressão pulsional, o ego, a fim de se proteger das imposições superegoicas, interditaria qualquer processo de assimilação e identificação com a figura repressora. Disto resulta não um superego integrado ao ego do indivíduo, como seria comum, "mas um superego isolado composto de elementos da autoridade repressora, adotados de forma dissociada do ego" (Silva, 2001, p. 65).

Se o superego encontra-se isolado das outras estruturas psíquicas, como fica então a questão do recalque no caráter impulsivo? Vale lembrar que o recalque é um dos destinos da pulsão, como mencionado no segundo capítulo desta pesquisa, e é efetuado tanto pelo ego obediente ao superego, quanto pelo próprio superego (Freud, 1933[1932]). Em poucas palavras, o recalque seria então uma força inconsciente perpetrada contra as representações pulsionais do id que ameaçam a estabilidade da vida psíquica forçando a sua consciência.

No caso do caráter impulsivo, a comunicação entre o superego e o ego é falha. Com isso, o ego um tanto míope em relação ao mundo externo e surdo às exigências superegoicas, fica à mercê das pulsões do id. A consequência é a "falta de eficácia do superego para efetuar o recalque e produzir formações reativas, bem como uma deficiência dessa eficácia, no mecanismo de moções pulsionais em 'crimes de culpa' (Freud)” (Reich, 1925, p. 82). 
No entanto, ao contrário do que se possa imaginar, o fato de o superego estar isolado não significa que ele seja inócuo, pelo contrário ele é extremamente rigoroso e prejudicial. Acontece que, sem a ajuda do ego para intermediá-lo, e sem poder auxiliar o ego frente às investidas libidinais do id, o superego atua de forma independente. Assim, de um lado temos um ego inundado pelas pulsões, impulsivo e sem considerar a realidade, e de outro temos um superego repressor, que não deixa de observar e castigar, gerando no ego uma necessidade de punição aniquiladora. Nestes casos, os atos impulsivos se manifestam claramente como impulsos agressivos sádicos ou masoquistas.

Ou seja, frente às pulsões o 'caráter impulsivo' age de forma inescrupulosa e sem limites. No entanto, com a ação do superego isolado, na mesma medida em que a pulsão sádica é levada para fora, esta (pulsão sádica) também vai atuar na direção do próprio indivíduo, fazendo-o agir de forma igualmente violenta para consigo. "O superego isolado funciona como uma pulsão recalcada e cria a necessidade de punição, que habitualmente busca a satisfação através de manifestações masoquistas evidentes" (Reich, 1925, p. 82 - grifo nosso).

Em suma, o superego "se origina de um investimento objetal abandonado e consiste em todas as exigências feitas anteriormente ao ego pulsional pelos pais ou outros indivíduos que cuidaram da criança” (Reich, 1925, p. 21). No caso extremo de um caráter impulsivo, este superego torna-se isolado e atua, ele próprio, como uma pulsão recalcada, criando a necessidade de punição - isto é, enquanto a pulsão sexual recalcada busca a satisfação, o superego isolado busca a punição habitualmente masoquista.

No entanto, apesar de ressaltar a particularidade da reação à frustração pulsional na patologia impulsiva - insuportável ao ego do paciente -, o autor irá lembrar que: "pode-se provar que nenhuma frustração é aceita sem que se gerem impulsos de ódio" (Reich, 1925, p. 20). Esta frase é importante, pois destaca que não é só nos casos impulsivos que o ódio advém da frustração, mas que toda frustração gera impulsos de ódio. Esta ideia vai ser posteriormente desdobrada pelo autor até resultar na sua teoria sobre o masoquismo em 1932.

Contudo, acompanhando o caminho tracejado por Freud, Reich em 1925 ainda não se opõe claramente contra o masoquismo erógeno proposto pelo metapsicólogo em 1924, pelo contrário, irá citá-lo concordando com a sua premissa: "Por ora, contento-me em mencionar a afirmação de Freud de que o 
masoquismo era originalmente erógeno, tomando a forma de sadismo quando dirigido para o mundo externo e somente depois (...) tornando-se masoquismo secundário" (Reich, 1925, p. 20). Isto significa dizer que, além de um masoquismo secundário oriundo do sadismo, Reich (1925) concorda que certa agressividade existiria no sujeito antes de ter sua satisfação pulsional frustrada e retornada para si (masoquismo secundário).

Porém, olhando atentamente, pode-se perceber que mesmo concordando com Freud (1924), neste texto de 1925 encontra-se o germe das críticas de Reich acerca da pulsão de morte, principalmente no que tange à sua ulterior avaliação sobre o masoquismo originário (impulso inato à autodestruição). Ou seja, as ideias sobre o masoquismo e a agressividade na obra de Wilhelm Reich vão ser modificadas com o tempo. Isso é importante, pois estes conceitos serão a base do argumento do autor contra a ideia de pulsão de morte apresentada por Freud em 1920.

Assim, antes de iniciar a questão do masoquismo, convém realizar uma rápida digressão utilizando o texto de 1927 para melhor compreender como o autor concebia a composição do caráter neurótico em termos 'econômicos sexuais $^{24}$.

Como visto no segundo capítulo do presente trabalho, Reich vai dedicar sua atenção à questão dos transtornos sexual-genitais que acompanham as neuroses. Assim, em 1927 esta questão será abordada sob a perspectiva da pulsão de destruição, considerando que a "intensidade do instinto de destruição (isto é, das manifestações de ódio, da agressividade, da brutalidade e do sadismo) depende ou da possibilidade atual de satisfação sexual [neurose atual] ou da pressão exercida pela estase somática da libido [psiconeurose]” (Reich, 1927, pp. 209, 210 - grifo do autor).

Reich (1927) então retoma a tese exposta em 1925 sobre o caráter impulsivo, expandindo a ideia de que o ódio decorre da frustração da satisfação pulsional e considerando a frustração no contexto da libido. Ou seja, enquanto que em 1925 a sílaba tônica recai sobre a questão do superego (segunda tópica freudiana), em 1927 o acento realça a dinâmica libidinal.

\footnotetext{
24 'Segundo Reich, o termo 'economia sexual' refere-se ao modo de regulação da energia sexual do indivíduo. A economia sexual designa a forma por que um indivíduo utiliza a sua libido. Os fatores que determinam este modo de regulação são de natureza psicológica, sociológica e biológica" (Reich, 1927/s.d., p. 266 - glossário).
} 
Por conseguinte, Reich (1927) vai considerar que 'a pulsão de destruição depende da estase libidinal' (Reich, 1927, p. 209). A estase libidinal acontece quando uma satisfação pulsional é interrompida. A estase consiste no processo econômico em que a libido que não consegue projetar-se para o exterior, regressa a formações internas do psiquismo. A energia é assim bloqueada, acumulada e encontrará a sua utilização na constituição dos sintomas (Reich, 1927, p. 267).

Considerando o conceito de ambivalência - amor e ódio voltados para a mesma pessoa - o mesmo objeto que é amado por cuidar e gratificar as pulsões, também é odiado por limitá-las e frustrá-las. "Qualquer frustração suscita ódio e ambivalência em relação ao objeto que impõe os limites à satisfação. Quanto mais forte tiver sido a irrupção da frustração, mais a fase do ódio será grande" (Reich, 1927, p. 214).

Em termos de 'estase libidinal' pode-se concluir que toda vez que a libido é bloqueada e impossibilitada de atingir sua finalidade, o sentimento de ódio vem como resultado. "O ódio é afinal de contas a reação natural a uma frustração ou a uma limitação na procura do prazer" (Reich, 1927, p. 218).

Segundo Reich (1927) este ódio vem acompanhado de um desejo de vingança, e a combinação deste desejo com a 'castração' do intuito da pulsão sexual (gerando a estase libidinal) cria a tendência sexual para a destruição e o sadismo. Para compreender melhor este curso de sentimentos, pode-se imaginar a seguinte sequência:

Estase - Ódio - Vingança - Sadismo/destruição - Culpa/autodestruição (masoquismo).

O conceito de castração significa justamente a proibição de levar até o fim os desejos sexuais incestuosos. Porém, a satisfação sexual incestuosa pode, enquanto sublimada, ser realizada no amor. No entanto, mesmo com a sublimação, há sempre um resto de libido - a libido na sua forma bruta - que vai pressionar para ser satisfeita de qualquer maneira. Todavia, a castração, quando eficiente, vai incidir também na libido 'bruta', fazendo-a retornar e se acumular como estase libidinal.

A castração é fundamental para o amadurecimento do psiquismo, entretanto isto não isenta o indivíduo de pagar com ódio o preço por esta interdição. Este 
ódio gera no indivíduo o desejo de vingança por ter sido castrado, e este desejo se expressa na forma de agressividade e sadismo para com aquele que o frustrou. "Mas como o objeto odiado é ao mesmo tempo amado, dá-se o desenvolvimento de uma angústia perante a realização de tais impulsos relativamente ao objeto amado; esta angústia de agressão junta-se a angústia de castração: se queremos roubar o falo do nossa pai, temos também que recear sermos castrados" (Reich, 1927, p. 218).

Levando em conta a ambivalência desta situação, a vontade de agredir vem acompanhada da culpa por agredir a quem se ama. Dessa forma, Reich (1927) conclui que "é sobretudo o amor, o amor do objeto assim como o amor próprio, que cria a angústia moral [culpa]" (Reich, 1927, p. 218).

Vejamos, culpa e punição são dois conceitos distintos e para o autor decorrem ambos, em última instância, da frustração pulsional. A culpa sucede da ambivalência - odiar e agredir o objeto amado - que é oriunda do impedimento (pelo objeto amado) da plena satisfação da pulsão sexual. A punição se origina das demandas do superego (ou, em casos extremos, do superego isolado), também procedente deste mesmo impedimento da satisfação pulsional pelo objeto amado. Com isso, qualquer tentativa de relacionar estes conceitos com uma pulsão inata de agressão ou autodestruição, será rebatida por Reich.

Retomando a ideia inicial do texto de 1927, conclui-se que a pulsão de destruição, expressa no sadismo e no masoquismo, depende da energia frustrada, bloqueada e acumulada, ou seja, da estase libidinal. "De um lado como do outro, constatamos a mesma coisa: o ódio depende da intensidade da recusa de amor, o instinto de destruição depende da estase libidinal” (Reich, 1927, p. 218).

Resumindo, em 1925 Reich equipara o 'superego isolado' com a pulsão de autodestruição, uma vez que este superego cria no sujeito a "necessidade de punição". No entanto, mesmo o superego atuante no neurótico (que não se caracterizaria como 'isolado') também exerce a função de vigiar e punir. O autor então se ampara nas ideias de Freud e vai considerar o superego a repressão internalizada, efeito de castigos e correções impostas pelos pais.

Em 1927, Reich vai reelaborar essa ideia pelo viés econômico sexual. Ou seja, enquanto em 1925 o autor descreve a punição praticada pelo indivíduo a si mesmo como efeito do superego punitivo (ponto de vista tópico), em 1927 é pelo 
ponto de vista econômico (estase da libido) que o comportamento destrutivo é explicado.

Essa ideia o acompanha inclusive no texto de 1932, quando rompe expressamente com o conceito de pulsão de morte. Neste texto, como se verá, Reich descreve com mais detalhes a sua tese sobre o masoquismo.

\section{6}

\section{O masoquismo em Freud e Reich}

Antes de tudo, foi visto que Freud (1920) introduziu a compulsão à repetição como indicativo da pulsão de morte, ou seja, como evidência de sua ação. Esta ação estaria além do princípio do prazer, haja vista que a compulsão à repetição é desprazerosa e não faz sentido pensá-la como submetida ao princípio do prazer, que visa justamente evitar o desprazer.

O metapsicólogo também citou vários exemplos de 'compulsão à repetição' que se encaixariam tanto na categoria 'repetição do mesmo' quanto na categoria 'repetição diferencial' descritas por Garcia-Roza (1986). A repetição seria então o indicativo da pulsão de morte, seja ela fusionada a Eros (repetição diferencial), ou na expressão pura e independente de Thânatos (repetição do mesmo). Dessa forma, a 'compulsão a repetição' resultante da desfusão de Eros e Thânatos, reveladora da pulsão de morte, teria a sua expressão máxima no masoquismo erógeno, que, como veremos, corresponde à pulsão de morte operante no organismo (Freud, 1924, p. 182).

Além da repetição Freud (1920) também apresentou o sadismo como o exemplo da pulsão de morte e sugeriu o masoquismo primário como indício da existência desta pulsão (Freud, 1920, pp. 64, 65). Em 1924 Freud retoma o ‘masoquismo primário' sugerido em 1920 e o descreve como 'masoquismo erógeno', relacionando-o à pulsão de morte, assim como a função sexual se relaciona com Eros. Dessa forma, esta força que não é sexual (pulsão de morte), opera de maneira tão impetuosa quanto a energia sexual. No entanto, o objetivo desta força não sexual é o de retornar ao estado primeiro da matéria, atuando na tentativa de desfazer a ação de Eros.

O masoquismo, evocado por Freud em 1920, foi pensado num primeiro momento - nos 'Três Ensaios' em 1905 - como a pulsão componente 
complementar ao sadismo e deveria ser encarado como um sadismo que se voltou para o próprio ego do sujeito. Revendo este conceito, Freud (1920) justapõe a ideia de masoquismo com a ideia de repetição.

O autor (1920) parte do princípio que não há diferença entre uma pulsão voltar-se do objeto para o ego ou do ego para o objeto. Ou seja, se no masoquismo há um retorno para o ego do sujeito, o próprio movimento de 'retornar' indicaria a existência de um estado anterior, e este movimento seria na verdade uma regressão (Freud, 1920, p. 65). Uma regressão a um masoquismo primário, posteriormente chamado de erógeno (1924), que existiria desde sempre na constituição do indivíduo. Este masoquismo erógeno seria, portanto, o exemplo que provaria a existência da pulsão de morte.

Em 1924 Freud escreve 'O problema econômico do masoquismo' e retoma a questão que deixou em aberto em 1920 sobre a possibilidade de existir um masoquismo primário. Neste texto o metapsicólogo escreve que devemos buscar a base do masoquismo erógeno - prazer no sofrimento - "ao longo de linhas biológicas e constitucionais" (Freud, 1924, p. 179). E completa:

Estando-se preparado para desprezar uma pequena falta de exatidão, pode-se dizer que o instinto de morte operando no organismo - sadismo primário - é idêntico ao masoquismo. (...) Esse masoquismo [erógeno] seria assim prova e remanescente da fase de desenvolvimento em que a coalescência (tão importante para a vida) entre o instinto de morte e Eros se efetuou (Freud, 1924, p. 182).

É com base nesta ideia de um masoquismo erógeno, que pressupõe uma base biológica para o desprazer e que é "idêntico" à pulsão de morte que opera no organismo, que Reich (1932) constrói sua crítica. Em 1932 no 'Caráter Masoquista' Reich vai deixar claro que "o masoquismo não é uma pulsão biologicamente determinada; pelo contrário, uma pulsão secundária no sentido econômico-sexual, isto é, o resultado de um recalque de mecanismos sexuais naturais" e "não existe um empenho biológico pelo desprazer; por isso não há nenhuma pulsão de morte" (Reich, 1932, p. 215 - nota do editor).

No texto 'Algumas observações sobre o conflito básico entre necessidade e mundo externo', Reich (1933) desenvolveu os argumentos expostos no artigo de 1932. Para o autor existe uma exigência pulsional sexual que dirige seu investimento para o mundo exterior (pais, cuidadores, educadores, sociedade) e que recebe, em contrapartida, uma ameaça de punição. 
Essa ameaça de punição se torna constante, submetendo o sujeito, que a internaliza. A internalização dessa ameaça acontece não sem prejuízo, mas ao contrário, gerando no campo psíquico afetos de angústia, raiva e culpa, e no campo 'econômico sexual' a estase libidinal. Dessa forma sempre que o sujeito se vê frustrado na sua tentativa de investir em algum objeto, esse mesmo investimento se volta contra si, intensificando tanto o desejo (impulso inicial) quanto os afetos e a estase libidinal. Assim o sujeito 'constrói' em si um reservatório de angústia (estase) que, com o passar do tempo, passa a ser uma fonte de impulsos frustrados, exteriorizados como agressividade (no sentido de um ato violento), tanto em direção aos outros quanto a si mesmo (masoquismo), podendo resultar, em último caso, em autoaniquilamento:

Tal como o mundo se torna uma realidade externa absolutamente desagradável, também o aparelho pulsional se torna uma realidade interna absolutamente desagradável. Contudo, dado que a força motriz fundamental da vida é a tensão com a esperança de uma possibilidade de alívio - isto é, de obtenção de prazer -, uma criatura externa e internamente privada dessas possibilidades desejará deixar de viver. O auto-aniquilamento converte-se na possibilidade única e final de alívio, de modo que podemos dizer que, mesmo na vontade de morrer, o princípio do prazer-desprazer está expresso (Reich, 1933, p. 263).

Vimos que Freud (1924) sugere que o prazer no sofrimento deve ser buscado numa orientação constitucional. Para Reich (1933), afirmar a existência de bases biológicas e constitucionais do sofrimento é aliviar o papel do mundo externo (externo ao sujeito e interno a este como instância superegoica) na constituição desse sofrimento. "Essa nova teoria remontou o conflito psíquico aos elementos internos e diminuiu, cada vez mais, o papel supremo do mundo externo, frustrante e punitivo" (Reich, 1932, p. 222).

Assim, ao submeter a vontade de morrer ao princípio do prazer-desprazer, Reich (1932) responsabiliza a sociedade pelo sofrimento que é, segundo o autor, oriundo das repressões à sexualidade. Ou seja, a ideia da existência de um desprazer (sofrimento, angústia) que aponta para 'além do princípio do prazer' indicaria também o limite do método psicanalítico, pois sinalizaria que com este sofrimento não há o que ser feito, haja vista que sua causa é inata.

Para melhor entender esta perspectiva sugerida por Reich (1933), retornemos ao texto 'Caráter Masoquista'. Reich (1932) interpretou a questão do masoquismo erógeno proposto por Freud (1924) da seguinte maneira: “considerava-se o masoquismo primário a manifestação independente da pulsão 
de morte de base biológica, baseada nos processos de diferenciação de cada célula do organismo" (Reich, 1932, p. 219). Essa interpretação dialoga com a seguinte passagem do texto freudiano de 1924 :

Se remontarmos um pouco atrás, para nossa hipótese das duas classes de instintos que consideramos como operantes no organismo vivo, chegamos a outra derivação do masoquismo, a qual, porém, não está em contradição com a anterior. Nos organismos (multicelulares), a libido enfrenta o instinto de morte ou destruição neles dominante e procura desintegrar o organismo celular e conduzir cada organismo unicelular separado [que o compõe] para um estado de estabilidade inorgânica (por mais relativa que essa possa ser). A libido tem a missão de tornar inócuo o instinto destruidor e a realiza desviando esse instinto, em grande parte, para fora - e em breve com o auxílio de um sistema orgânico especial, o aparelho muscular - no sentido de objetos do mundo externo (Freud, 1924, p. 181).

Ou seja, haveria em cada organismo a oposição entre libido e pulsão de morte onde a decomposição do organismo multicelular seria necessária como forma de tornar ineficaz a pulsão destruidora (mas, ocasionaria a autodestruição). Com o desenvolvimento do aparelho muscular, essa pulsão seria desviada para fora em direção a objetos externos (sadismo). Examinando esta citação compreende-se a passagem onde Freud (1924) menciona que a base do masoquismo erógeno deve ser buscada ao longo de linhas biológicas e constitucionais.

Para Reich (1932), em termos fisiológicos, a pulsão ${ }^{25}$ exprime a função de alternância entre tensão e relaxamento, “o ritmo básico do metabolismo no atendimento à necessidade de alimento e satisfação sexual" (Reich, 1932, p. 220). Isto significa dizer que o autor não concorda com a ideia da decomposição de um organismo via atuação de um impulso mortífero.

O fenômeno fisiológico apresentado por Reich (1932) é o de pulsação. O organismo pulsa entre tencionar e relaxar, tal como observado na função do orgasmo, cuja curva orgástica ilustra a ação da libido desde a excitação até o relaxamento. Assim como em termos metapsicológicos, a pulsão, por ser uma konstant kraft, apresentaria esta característica de pressão e satisfação que só cessa com a morte.

Considerando esta pulsação, o que levaria um organismo à morte seria o processo de enrijecimento: "Isso faz sentido especialmente se pensamos na calcificação dos tecidos na velhice. (...) Aquilo que se tornou fixo e imóvel, isto é,

\footnotetext{
${ }^{25}$ O autor utiliza este termo no singular. Reich (1932) está considerando uma única pulsão e não duas como defende Freud.
} 
o que fica para trás, como a escória do processo vital, atrapalha a vida e a sua função principal: alternância entre tensão e relaxamento, o ritmo básico do metabolismo no atendimento à necessidade de alimento e satisfação sexual" (Reich, 1932, pp. 219, 220).

Em outras palavras, segundo Reich (1932), o que leva um organismo à morte é o fato do enrijecimento interromper o processo de 'pulsão', e não o enrijecimento em si. Dessa forma, o autor considera que todo processo que ocorre no organismo é, sem dúvida, voltado para a vida. Isto inclui o enrijecimento, que é 'a escória do processo vital', o resto, e que é produzido e estruturado a partir da própria vida. “(...) a involução fisiológica do organismo, sua morte gradual, começa assim que a função do aparelho sexual, a fonte da libido, enfraquece. Por isso, a morte não precisa ser baseada em outra coisa que não a cessação gradual do funcionamento do aparelho vital" (Reich, 1932[1933], p. 224).

Dessa forma, para Reich (1932), o masoquismo erógeno, assim como a pulsão de morte, não se sustentaria pelo viés biológico. Já a compulsão à repetição, enquanto "significava a lei segundo a qual toda pulsão luta para estabelecer o estado de repouso [relaxamento] e, além disso, para reexperimentar prazeres anteriormente desfrutados, não havia nada a objetar" (Reich, 1932[1933], p. 223). Reich (1932) compreendia a compulsão à repetição não como a ação da pulsão de morte, mas totalmente dentro da estrutura do princípio do prazer. Lembrando que a formulação do princípio do prazer-desprazer é, para Reich (1932), também apoiada nas leis fisiológicas de tensão (desprazer) e relaxamento (prazer).

Assim, dentro da estrutura do princípio do prazer, a compulsão à repetição é uma hipótese teórica importante. Contudo, foi justamente para além do princípio do prazer que o princípio da compulsão à repetição ganhou sua formulação mais importante, como uma hipótese para a explicação de fatos para os quais o princípio do prazer era supostamente insuficiente (Reich, 1932, pp. 223, 224).

Com isso, Reich nos conduz de volta a 1925. O autor, nesta época, não se opunha à pulsão de morte, ao conceito de masoquismo erógeno ou à compulsão à repetição (como 'repetição do mesmo' ou 'repetição sem disfarces'). Inclusive o 'caráter impulsivo' é enunciado como um exemplo da tese defendida por Freud (1920) que considerava existir "na mente uma compulsão à repetição que sobrepuja o princípio do prazer" (Freud, 1920, p. 33). Esta tese foi construída por 
Freud (1920) através de sua experiência na clínica com pacientes cujo comportamento denotava a "perpétua recorrência da mesma coisa" (ibid.). Ou seja, ao invés de apresentarem conflitos neuróticos 'comuns', os sintomas são expressos "por uma repetição das mesmas experiências" (ibid.).

No entanto, apesar de enquadrar o 'caráter impulsivo' como um exemplo de compulsão à repetição, concebendo assim a pulsão de morte, o autor encontra outra solução para resolver o enigma dos pacientes impulsivos, atribuindo sua explicação nem a pulsão de morte e nem ao masoquismo erógeno. Reich (1925) deixa claro que a solução está no 'superego isolado'.

Em 1927, olhando este mesmo caráter pelo viés da 'economia sexual', percebe-se que Reich (1927), aparentemente, não refuta a hipótese da pulsão de morte. No entanto, a solução econômica que encontra para a pulsão de destruição não tem por fonte um impulso à morte, mas encontra origem na estase libidinal que alimenta a pulsão.

\section{7}

\section{Agressividade e o conflito entre necessidade e mundo externo}

Como constatado ao longo dos textos da década de 20 à década de 30, Reich foi mudando sua ideia sobre a segunda teoria pulsional, até romper de vez com o conceito de pulsão de morte em 1932. Contudo, uma questão ficou em aberto: Reich (1932) considera a agressividade o resultado das frustrações sofridas à sexualidade. No entanto, o autor também reconhece outro papel para a agressividade: colocando-a junto à libido esta seria necessária à preservação da vida. Como compreender esta contradição?

Para clarear esta questão, em 1942 no texto 'Destruição, agressão e sadismo', Reich define melhor suas ideias acerca do conceito de 'agressividade'. No mencionado texto de 1942, ao mesmo tempo em que Reich afirma ser necessária uma dose de agressividade no ato sexual, ele também sustenta que a agressividade não tem conotação sexual no sentido estrito do termo, pois esta não visa ao prazer, mas se livrar do desprazer "embora libertar-se do desprazer seja uma experiência semelhante ao prazer" (Reich, 1942, p. 139).

$\mathrm{Na}$ visão de Reich (1942) a agressividade serviria para proteger uma criatura ameaçada, destruindo a fonte do perigo. Nesse caso a morte ou a destruição do 
objeto é a meta biologicamente determinada para proteção da vida, enquanto organismo vivo. Por isso o autor afirma que a meta não é a destruição, mas a proteção da vida: "Destruo uma situação perigosa porque quero viver e não quero ter nenhuma angústia” (Reich, 1942, p. 138).

Percebe-se então que para Reich (1942) há uma diferença entre agressividade e destruição. A agressividade seria uma meta biologicamente necessária para a proteção do organismo vivo. A destruição, diferente da agressividade, é a expressão da libido frustrada voltada para o mundo externo. $\mathrm{Ou}$ seja, em um organismo auto-regulado sempre vai haver uma dose de agressividade, no entanto, posto que na auto-regulação o organismo é capaz de descarregar seus excessos, não haveria comportamentos destrutivos ou autodestrutivos.

Reich (1942) também considera que a agressividade serviria às pulsões sexuais e de autoconservação, mas não se confundiria com elas, pois, para o autor a tensão sexual seria sentida como um excesso, um aumento de carga no organismo a ser descarregado, e a fome (paradigma da pulsão de autoconservação) seria a falta que impele o organismo, utilizando-se da libido como força propulsora, em direção ao mundo e ao objeto que irá satisfazê-la. Assim, a agressividade é necessária à pulsão sexual para a realização do coito, e à pulsão de autoconservação no próprio ato de mastigar, destruir e deglutir o alimento.

Para compreender melhor a sua hipótese, faz-se necessário retornar à primeira dualidade pulsional. A primeira teoria apresentada por Freud (1915) em "Pulsão e suas vicissitudes" marca a diferença entre pulsão sexual e pulsão de autoconservação (ou pulsão do ego), sendo que ambas as pulsões, num segundo momento, dirigem seus esforços em direção ao mundo externo na tentativa de obter daí suas satisfações.

Reich (1942) concorda com Freud (1915) ao dizer que é a pulsão de autoconservação quem parte primeiro em busca de um objeto externo, pois utilizando a fome como paradigma desta pulsão, é necessário o leite materno (que se encontra fora do sujeito) para aplacar o desprazer gerado pela ausência de alimento, ao contrário da pulsão sexual que, neste primeiro momento, não encontra seu objeto 'do lado de fora', mas no próprio sujeito (prazer de órgão). No entanto, ainda concordando com Freud (1915), Reich (1942) afirma que sem a 
pulsão sexual, ou libido, a pulsão de autoconservação não teria a carga, a quantidade de energia necessária para ir em direção ao seu alvo, por isso elas se encontram, a princípio, entrelaçadas. Freud (1915) usa a palavra 'apoio' para sugerir esta relação, onde no começo, as pulsões sexuais apoiam-se nas pulsões do ego, seguindo os caminhos indicados por estas para encontrarem um objeto (Laplanche e Pontalis, 1982).

Assim, uma parte das pulsões sexuais permanece ligada às pulsões egoicas, dando-lhes componentes libidinais. Dessa forma, quando uma pessoa come, é importante distinguir conceitualmente a pulsão alimentar (de auto-conservação), cujo alvo é a ingestão do alimento e a pulsão oral (sexual), cuja finalidade é o prazer da zona erógena oral.

Em 1933 Reich exemplifica esta mesma ação utilizando seus conceitos de contração e expansão. Onde há falta de alimento o organismo se expande (se aproximando do mundo externo), para obter isto que lhe falta. Dessa forma ele passa de um estado de 'baixa tensão' (fome, ausência de alimento) para um estado de 'alta tensão', gerando a necessidade de descarga.

Uma imagem possível de representar esses estados é a de um balão de festa. Vazio, suas bordas se encontram flácidas e sem tensão, quando cheio, suas bordas se expandem exercendo pressão, como se fossem explodir. Tanto na baixa tensão como na alta tensão experimenta-se o desprazer, mas somente na alta tensão há uma correlação direta entre tensão real e a sensação de desprazer, pois, é necessária uma tensão (aumento de carga) para haver uma descarga e assim produzir o prazer (redução de desprazer). $\mathrm{Na}$ 'baixa tensão' não há carga suficiente para ser descarregada, logo o desprazer não pode ser aliviado.

Por isso, a energia sexual está sempre a serviço da satisfação da fome, enquanto a absorção do alimento, inversamente, introduz aquelas substâncias que, através de um processo físico-químico, levam finalmente as tensões libidinais. Assim como a absorção do alimento é a base da existência e das funções libidinais, estas são a base das realizações produtivas - incluindo a mais primitiva, a locomoção (Reich, 1933, p. 257).

Isto posto, nota-se que em se tratando da primeira teoria pulsional, Reich não considera haver uma oposição entre pulsão sexual e pulsão de autoconservação. O autor, pelo contrário, salienta a complementaridade entre ambas as pulsões que primitivamente dependem uma da outra. 
Vimos também que, pelo ponto de vista orgânico-energético de Reich, a ideia de um impulso à morte preexistente no organismo não se sustenta. Ou seja, Reich considera a existência de Eros (que abarca as necessidades sexuais e de nutrição), mas não de Thânatos. Sendo assim, a hipótese de uma dualidade pulsional fica prejudicada, comprometendo também a ideia de um conflito pulsional subjacente às neuroses.

Reich (1933) conclui então que o primeiro conflito não poderia ocorrer entre pulsões, mas entre impulsos do ego que visam estabelecer contato com o mundo externo (visando descarregar tensões internas relacionadas às necessidades) e o mundo externo.

(...) somos capazes de descobrir que, na base de todas as reações, existe a antítese não entre amor e ódio, e certamente não entre Eros e pulsão de morte, mas entre ego ("pessoa"; id = ego do prazer) e mundo externo. Num nível elementar, apenas um desejo brota da unidade biopsíquica da pessoa: o desejo de descarregar tensões internas, pertençam elas a esfera da fome ou da sexualidade. Isso é impossível sem o contato com o mundo externo. Por isso, o primeiro impulso de toda a criatura deve ser um desejo de estabelecer contato com o mundo externo (Reich, 1933, p. 256).

Assim, para o autor, o conflito não refletiria mais a oposição entre sexualidade e ego, nem entre Eros e Thânatos, mas entre necessidade e mundo externo. Essa é a proposta original de Reich em 1933.

Para ilustrar sua declaração, Reich (1933) traça o caminho que a libido percorre até se voltar contra o próprio sujeito transformando-se em impulso destrutivo e autodestrutivo: a princípio há o investimento voltado para fora (mundo externo), mas com a impossibilidade de realização devido à ameaça de castigo, a libido recua para dentro (fuga narcísica). Esse recuo é sentido como angústia, resultado da estase (represamento da libido). Outra possibilidade de recuo acontece pela ação muscular, desta vez, ao invés da libido realizar uma fuga narcísica, é o aparelho locomotor que se afasta do perigo. Além da fuga para o centro do corpo e a fuga muscular, há a eliminação da fonte de perigo através de um ‘impulso destrutivo' cujo objetivo é evitar a angústia.

No entanto, na fuga narcísica, a angústia se instala e ameaça o organismo internamente. Assim, a única forma de tentar fugir da angústia é expelindo-a, numa nova tentativa de direcioná-la para fora. Acontece que desta vez o mundo externo frustra não só a satisfação da libido como também o da "pulsão destrutiva". Reich (1933) chama atenção para este movimento como sendo a 
possível causa do sadismo: "Toda frustração da libido provoca intenções destrutivas que, por sua vez, podem se transformar facilmente em sadismo, pois este engloba o impulso libidinal e destrutivo" (Reich, 1933, p. 261). E conclui:

Contudo, dado que a emergência de cada novo impulso provoca a atitude punitiva do mundo externo, segue-se uma cadeia sem fim, cujo primeiro elo é a inibição que induz ao medo da descarga libidinal. A inibição do impulso agressivo pela ameaça de punição proveniente do mundo externo não só aumenta a angústia e impede a descarga da libido muito mais do que anteriormente; ela também dá origem a uma nova antítese. Dirige o impulso destrutivo em parte contra o mundo e em parte contra o ego, acrescentando assim novos antagonismos: entre pulsão de destruição e pulsão de autodestruição e entre sadismo e masoquismo (Reich, 1933, p. 261262).

Segundo o próprio autor, todos os fenômenos clínicos, dos quais se crê poder deduzir uma pulsão de morte, podem ser desmascarados como indícios e consequências de uma fuga narcísica do mundo. A autodestrutividade é a manifestação de um impulso destrutivo voltado contra si mesmo, ocasionada por uma repressão externa. Dessa forma Reich finaliza:

O desejo consciente de morte, de paz, de nada ("o principio do nirvana") só ocorre numa condição de desesperança e ausência de satisfação sexual, especialmente genital. É, em resumo, a manifestação de uma resignação completa, um refugiar-se no nada, escapando de uma realidade que se tornou exclusivamente desagradável. (...) Todo impulso libidinal que não é dirigido para o externo, isto é, que corresponde a uma retirada para dentro do próprio ego - em resumo, todo fenômeno de regressão narcísica é tomado como prova da existência da pulsão de morte. Na realidade, não passam de reações a frustrações reais da satisfação das necessidades libidinais e de se saciar a fome - frustrações causadas por nosso sistema social ou por outras influencias do mundo externo (Reich, 1933, p. 262).

Mesmo após seu desligamento da Associação Psicanalítica Internacional em 1934, Reich continuou com seus estudos em torno da biologia e, posteriormente, da biofísica e da física. No final dos anos 30, o autor alega ter descoberto um tipo de 'energia cósmica primordial', a energia orgone (também chamada de bioenergia ou energia da vida), cuja comprovação seria possível através de contadores Geiger-Mueller. Esta energia pulsante, que tudo principiou, é reguladora da vida e também responsável por criar seus próprios transportadores (carriers) que, segundo o autor, seriam: o hidrogênio, oxigênio, carbono, nitrogênio e todos os seus compostos, $\mathrm{H} 2 \mathrm{O}, \mathrm{O} 2, \mathrm{CO} 2$, carboidratos, gorduras e 
proteínas. Ou seja, é através destes 'transportadores' que a energia orgone atuaria no corpo vivo.

Em 1951, porém, o autor descobriu outra forma de manifestação desta mesma energia universal, cuja qualidade letal lhe rendeu o nome de DOR (dead energy orgone). Assim, OR e DOR formariam um par antitético como manifestações da mesma energia - energia cósmica universal - que, enquanto pulsando e em movimento é denominada por Reich de OR - energia orgone - e, enquanto estereotipada, fixada e cristalizada em um dos polos da pulsação (contração e expansão) é reconhecida como DOR.

Este tema não vai ser esmiuçado nessa pesquisa, pois fugiria do objetivo deste trabalho. No entanto, não seria possível deixar, ao menos, de comentá-lo, pois, é justamente com o advento da energia DOR que Reich (1951), poucos anos antes de sua morte, finalmente 'reconhece' a pulsão de morte freudiana.

Os caminhos da pesquisa e do pensamento humano são estranhos, de fato. A apresentação seguinte tentará mostrar que Freud tinha estado em contato com uma profunda realidade da natureza em geral, quando com quase setenta anos ele postulou hipoteticamente a existência de um obscuro, silencioso, e destrutivo "instinto de morte"; um instinto cuja função era trazer de volta ao silêncio e ao nada o que seu adversário "instinto de vida" havia transformado em formas de vida na imensidão do nosso planeta (Reich, 1956, p. 2 - tradução nossa).

A energia DOR então é a mesma energia cósmica universal, mas, indo em direção à morte. Esta assume uma direção à morte pois encontra-se represada, e este represamento impede o movimento de pulsação característico do modo de operação da energia OR. Assim a energia DOR impede o movimento pulsional gerado pela energia OR, prejudicando a troca do organismo com o meio externo e com isso inibindo as funções vitais. Esta energia estaria nas couraças musculares ${ }^{26}$ e seria responsável pelas doenças orgânicas, pela peste emocional, pelos desertos, e principalmente responsável pela morte.

Reich (1956) então encontrou a relação do seu conceito de 'energia letal' com a 'pulsão de morte'. No entanto, a sua ideia de 'pulsão de morte' não é exatamente aquela postulada por Freud (1920), ou seja, mesmo a adesão tardia de Reich (1956) a este conceito, viria com ressalvas. Isto se deve ao fato de Freud nunca ter deixado de considerar a existência de um par pulsional. No entanto para

\footnotetext{
${ }^{26}$ A 'couraça muscular' é um conceito reichiano que designa a soma total das atitudes musculares (espasmos musculares crônicos), que o indivíduo desenvolve como defesa contra a irrupção de afetos e sensações vegetativas, especialmente a angústia, a raiva e a excitação sexual.
} 
Reich, de fato, só há uma pulsão - a pulsão responsável pela vida - que ora se manifesta como energia pulsante, ora se manifesta como energia cristalizada que pode levar o organismo à morte. Assim:

Ainda é verdade e irrevogável que um instinto de morte, ou seja, uma tendência do 'Id' inconsciente de morrer, indo em direção a não existência não pode ser demonstrado clinicamente, e nunca será. Não existe tal coisa no reino do funcionamento psíquico ou emocional como um profundo desejo de morrer. O sistema 'vivo' emocional, só pode desejar viver, funcionando da forma mais plena possível. O velho dito freudiano de que na mente inconsciente não existe negação, ainda está de pé. O desejo de morrer é uma manifestação secundária de níveis superiores da mente (Reich, 1956, p. 4 - tradução nossa).

Conclui-se que o reconhecimento de Reich parece estar relacionado mais ao insight de Freud (1920), no sentido de ter percebido uma força mortífera que atua junto à vida, do que uma adesão ao conceito psicanalítico de Thânatos. Segundo a visão Reichiana tanto a pulsão de morte quanto a energia DOR seriam secundárias em relação à pulsão de vida ou a energia orgone. 


\section{Considerações finais}

O caminho percorrido neste trabalho teve início com o conceito de pulsão na obra freudiana até a discussão deste conceito na obra de Reich, tendo como pano de fundo as duas teorias pulsionais. Assim, abordou-se primeiramente o termo Trieb e todas as suas nuances, com o objetivo de traçar um paralelo entre o termo coloquial alemão e o conceito Trieb na psicanálise de Freud.

Vimos que este termo era uma palavra de uso corrente do vocabulário alemão da época e que abarcava sentidos gerais e específicos. A tese de Hanns (1996) é que Freud escolheu este termo justamente pela sua abrangência:

O Trieb brotará no indivíduo como fenômeno somático-energético, sendo descrito por Freud como processo fisiológico (envolvendo termos como neurônios, nervos, fontes pulsionais situadas em glândulas etc.) e como processo energéticoeconômico (acúmulo de energia, descarga etc.). De outro lado, o Trieb aparecerá para o indivíduo, isto é, será percebido como fenômeno psíquico (ideia, vontade, dor, medo, sensações) e irá impedi-lo de praticar certas ações. Assim, o Trieb Brota como fenômeno físico e orgânico, e atinge a mente como fenômeno psíquico (Hanns, 1996, p. 351).

Ao longo do presente trabalho, pôde-se acompanhar como Freud abordou os sentidos de Trieb. Apesar do recorte da pesquisa ter limitado o campo de estudo do conceito Trieb entre o período de 1905 a 1920, a ideia da abrangência deste conceito foi evidenciada.

Em 1915, por exemplo, na primeira teoria pulsional, Freud definiu a pulsão (Trieb) como um tipo de estímulo (Reiz). A pulsão e o estímulo se diferenciam quanto a origem e finalidade: "Enquanto os estímulos não pulsionais são externos e ocasionais (luz, frio, etc...) os estímulos pulsionais provêm de fonte orgânica interna, são gerados incessantemente e têm finalidade" (Hanns, 1996, p. 352). Com isso, chegou-se a definição de pulsão como: um conceito na fronteira entre o psíquico e o somático; como o representante psíquico dos estímulos (Reiz) que se originam dentro do organismo e alcançam o psiquismo, e como uma medida da exigência de trabalho feita ao psíquico.

Enquanto ligado ao corpo, a pulsão se apresenta como um 'estímulo', no entanto, ao considerar este conceito como uma 'medida de exigência', a pulsão aparece mais próxima da ideia de um 'acúmulo de energia' que irá pressionar para ser descarregado (Drang). Dessa maneira, a pulsão coincide com um sentido mais abrangente, e menos pessoal. 
Porém, examinando os elementos que compõe a pulsão, Freud (1915) considerou não só o seu aspecto somático (fonte) e energético (pressão), mas os aspectos 'psicológicos' deste conceito. Ou seja, tanto o alvo como os objetos, seriam aspectos mais 'representacionais', pois, embora o alvo da pulsão seja sempre a satisfação, a forma como cada indivíduo irá buscar satisfazê-la é múltipla e singular. Com os objetos da pulsão a mesma coisa, aliás, estes são variáveis ao infinito e sua construção é, sobretudo, psíquica. Isto é, alvo e objetos são elementos mais específicos e pessoais.

Considerando o alcance do conceito de pulsão, Reich se dedicou à face mais energético-econômica deste conceito, que é a libido. Contudo, enquanto a psicanálise apresentou a libido como a expressão da energia pulsional no psiquismo: "O instinto sexual, a manifestação dinâmica do que, na vida mental, chamamos de 'libido' (...)” (Freud, 1923, p. 261), Reich a apresentou de outro modo.

Reich (1942) compreendia a libido freudiana como a energia da pulsão sexual: “A 'libido' de Freud não é, e não pode ser, senão a energia do instinto sexual", assim como considerava que o pensamento de Freud sobre a questão energética era “coerente e científico-natural (...)”(Reich, 1942, p. 35). O olhar científico-natural que Reich atribuiu a Freud sobre a questão energética fez diferença na abordagem escolhida por este autor ao estudar o conceito de libido.

Como visto, Reich se aprofundou no aspecto mais 'geral', 'absoluto' - para usar a terminologia de Hanns (1996) - do conceito de libido, desviando-se do seu aspecto 'individual' (psíquico). “Obviamente, porém, não se tratava de competir com Freud, nem de criar uma profissão, mas de levar adiante uma descoberta monumental. Havia em questão mais que a elaboração de material conhecido; tratava-se, essencialmente, de descobrir as bases biológicas da teoria da libido, através da experimentação" (Reich, 1942, p. 40).

Dessa forma, indo ao encontro do que acreditava ser a face mais orgânica da pulsão sexual, Reich (1927) desenvolveu seu conceito de 'energia orgástica'. A 'energia orgástica' é o caráter mais orgânico-energético da pulsão sexual e, através da 'função do orgasmo', esta energia se expressaria por meio de 'tensão carga - descarga - relaxação', provando ser esta "a fórmula do funcionamento da vida como tal" (Reich, 1942, p. 17). Considerando esta a 'fórmula da vida', a 'energia orgástica' seria então a 'energia vital'. "Para Reich, a função do orgasmo 
é a função vida em sua força potencial para a plena realização. Sem essa capacidade o organismo padece" (Jaber, 2006, p. 28).

Deduz-se a partir deste enunciado, que a pulsão originária para Reich é a pulsão sexual (energia orgástica), pois é esta a responsável pelo funcionamento da vida. Sendo assim, quando a energia orgástica se vê impedida de ser satisfeita (isto é, descarregada), esta produz 'estase', que é a 'energia sexual represada'. Consequentemente, o organismo acaba adoecendo por não ter disponível toda energia necessária para funcionar adequadamente.

Com o advento da segunda teoria pulsional em 1920, Freud reformulou a teoria de 1915 e colocou a pulsão sexual e a pulsão de autoconservação sob o signo de Eros (ou pulsão de vida), contrapondo-o à pulsão de morte. Em 1920 o metapsicólogo também enuncia a pulsão de morte como a pulsão primordial.

Os atributos da vida foram, em determinada ocasião, evocados na matéria inanimada pela ação de uma força de cuja natureza não podemos formar concepção. Pode ter sido um processo de tipo semelhante ao que posteriormente provocou o desenvolvimento da consciência num estrato particular da matéria viva.

A tensão que então surgiu no que até aí fora uma substância inanimada se esforçou por neutralizar-se e, dessa maneira, surgiu o primeiro instinto: o instinto a retornar ao estado inanimado (Freud, 1920, p. 49 - grifo nosso).

Se Freud (1920) sugeriu que a primeira pulsão é aquela cujo objetivo é retornar ao estado inanimado, então esta pulsão é a pulsão de morte. Esta afirmação mudou o rumo do que o autor havia afirmado na primeira teoria pulsional, onde o objetivo das pulsões era a satisfação pela via da descarga das tensões. Isto é, as pulsões, na primeira teoria pulsional, estavam submetidas ao Princípio do Prazer.

Na teoria das pulsões de 1920, Eros continuava respondendo ao Princípio do Prazer, porém a pulsão de morte (Thânatos) estava além deste Princípio e próximo ao Princípio do Nirvana que visava levar a zero qualquer quantidade de excitação, ou seja, silenciar a vida.

Além disso, em 1924 o metapsicólogo retomou um assunto que havia introduzido em 1920 e descreveu o 'masoquismo erógeno' como irredutível a um retorno do sadismo sobre a própria pessoa. $\mathrm{O}$ masoquismo erógeno seria então primário e voltado contra o próprio sujeito, sendo observado como autoagressão. A pulsão de morte teria, pois, no masoquismo erógeno a sua expressão mais pura; um impulso 'natural' que se destinava a autodestruição. 
Como defendia uma visão mais científico-natural da psicanálise, Reich não conseguia traçar um paralelo desta nova teoria pulsional com as descobertas que vinha realizando sobre a 'economia sexual'. O autor acreditava que o movimento pulsional é inerente à vida (a vida pulsa); a vida expande e contrai, tensiona e relaxa, gera carga e descarga, e a morte seria o resultado da cessação deste movimento.

A pulsação da vida foi observada por Reich tanto no decorrer de seus atendimentos no consultório, como analisada através de estudos na área de sexologia e biologia e, posteriormente, confirmados através de seus experimentos com Bions $^{27}$. Dessa forma, o autor afirmava que não existia um impulso inerente à vida que buscasse a morte, mas uma forma de funcionamento do organismo humano que poderia, por consequência da própria vida, levá-la à morte.

A partir desta afirmação colocaram-se algumas questões: como se sustentaria um dos pilares da teoria das pulsões, que é o dualismo pulsional, responsável pelo conflito subjacente aos conflitos psíquicos? Se Reich não considerava válido o conceito de pulsão de morte, quem se oporia a Eros? Se não são as pulsões em oposição, o que alimenta o conflito psíquico?

Considerando que, segundo Reich, a pulsão sexual é a pulsão primordial e não existiria na natureza um impulso à morte, não haveria, pois, para este autor outra pulsão que pudesse se opor a Eros. Dessa forma, Reich (1933) teve que encontrar a solução para o conflito psíquico em outro lugar.

Sendo fiel a seu raciocínio desde o início, Reich não negava os fenômenos de destruição e autodestruição (sadismo e masoquismo) e nem o fenômeno da 'compulsão à repetição'. Porém, estes fatos foram interpretados por ele como manifestações secundárias de um primeiro embate entre as 'necessidades' (Eros) e o mundo externo.

Assim, a resposta que Reich oferece para a compreensão de tais fenômenos clínicos parte da consideração de que, por trás de toda neurose ou patologia psíquica, a fonte que alimenta o conflito subjacente às doenças é a estase libidinal. A estase da libido, como visto, é o resultado da frustração da satisfação de uma necessidade em termos energéticos.

\footnotetext{
${ }^{27}$ Entre os anos de 1934 a 1939 Reich realizou inúmeros experimentos com o que chamava de 'Bions'. Reich acreditava que os "bions" eram uma forma rudimentar de vida, a meio caminho entre a vida e não-vida, descritos por ele como vesículas azuis, brilhantes e incandescentes.
} 
Em um primeiro momento a libido seria dirigida para fora com a intenção de ser acolhida e satisfeita pelo meio externo, no entanto, ao sofrer inúmeras restrições, as pulsões impedidas de se realizarem, acumulam-se no organismo como estases e carregam em si a frustração sofrida. Estas estases impedem o livre fluxo de energia no organismo, causando bloqueios corporais e alimentando as neuroses. Além disso, uma parte dessa libido frustrada pode se voltar para fora de forma violenta, causando a destruição.

À vista disso, o conflito interno seria secundário e ocasionado pela antítese entre 'energia orgástica' (libido) e a 'estase da libido' e seus bloqueios corporais e psíquicos (couraças). Reich a partir daí vai desenvolver a teoria e a técnica de ‘Análise do Caráter' (1927), com a intenção de resolver as questões clínicas descritas na 'Função do Orgasmo'. Esta técnica tem como princípio básico o restabelecimento da motilidade biopsíquica através da anulação da rigidez (encouraçamento) do caráter e da musculatura.

Assim, o próprio autor identificou a origem do problema e desenvolveu uma técnica terapêutica de base corporal, nomeada de técnica vegetoterápica de análise do caráter. Em virtude da delimitação do tema entretanto não coube ao presente trabalho abordar a técnica do análise do caráter que pela sua amplitude está a merecer um estudo específico. 


\section{Referências bibliográficas}

ALBERTINI, P. Reich - História das Ideais e Formulações para a Educação, $1^{\mathrm{a}}$ ed. São Paulo: Ágora, 1994.

Reich em Diálogo com Freud: Estudos sobre Psicoterapia,

Educação e Cultura, $1^{\text {a }}$ ed. São Paulo: Casa do Psicólogo, 2005.

BEDANI, A. Energética e epistemologia no nascimento da obra de Wilhelm

Reich. 2007. 176 p. Dissertação (Mestrado) - Instituto de Psicologia da Universidade de São Paulo.

ESTEVÃO, I. R. Retorno à Querela do Trieb: Por uma Tradução Freudiana. Cadernos de Filosofia Alemã/USP. São Paulo, n 19, 2012, pp. 79-106.

FREUD, S. (1950[1895]) "Projeto para uma psicologia científica". In: Edição

Standard Brasileira das Obras Psicológicas Completas de Sigmund Freud. v.1. Rio de Janeiro: Imago Editora, 1996. . (1898) “A sexualidade na etiologia das neuroses”. In: Edição

Standard Brasileira das Obras Psicológicas Completas de Sigmund Freud. v.8. Rio de Janeiro: Imago Editora, 1996. . (1905) “Os Três Ensaios Sobre a Teoria da Sexualidade”. In:

Edição Standard Brasileira das Obras Psicológicas Completas de Sigmund Freud. v.7. Rio de Janeiro: Imago Editora, 1996. 1906 [1905] "Minhas Teses Sobre o Papel da Sexualidade na Etiologia das Neuroses". In: Edição Standard Brasileira das Obras Psicológicas Completas de Sigmund Freud. v.7. Rio de Janeiro: Imago Editora, 1996.

(1910) “A Concepção Psicanalítica da Perturbação Psicogênica da Visão". In: Edição Standard Brasileira das Obras Psicológicas Completas de Sigmund Freud. v. 9. Rio de Janeiro: Imago Editora, 1996. - (1911) "Formulações Sobre os Dois Princípios do Funcionamento Mental”. In: Edição Standard Brasileira das Obras Psicológicas Completas de Sigmund Freud. v. 12. Rio de Janeiro: Imago Editora, 1996.

. (1912) "Sobre a Tendência Universal à Depreciação na Esfera do Amor (contribuições à psicologia do amor II)". In: Edição Standard 
Brasileira das Obras Psicológicas Completas de Sigmund Freud. v. 11. Rio de Janeiro: Imago Editora, 1996.

. (1913) “O Interesse Científico da Psicanálise”. In: Edição

Standard Brasileira das Obras Psicológicas Completas de Sigmund Freud. . v. 13. Rio de Janeiro: Imago Editora, 1996.

(1914) "Sobre o Narcisismo: Uma Introdução". In: Edição

Standard Brasileira das Obras Psicológicas Completas de Sigmund Freud. v. 14. Rio de Janeiro: Imago Editora, 1996.

. (1915) "Pulsões e Suas Vicissitudes". In: Edição Standard

Brasileira das Obras Psicológicas Completas de Sigmund Freud. v.14. Rio de Janeiro: Imago Editora, 1996.

(1920) “Além do Princípio do Prazer”. In: Edição Standard

Brasileira das Obras Psicológicas Completas de Sigmund Freud. v. 18. Rio de Janeiro: Imago Editora, 1996. (1923[1922] a) "Dois Verbetes de Enciclopédia". In: Edição

Standard Brasileira das Obras Psicológicas Completas de Sigmund Freud. v. 18. Rio de Janeiro: Imago Editora, 1996.

(1923 b) “O Ego e O Id”. In: Edição Standard Brasileira das Obras Psicológicas Completas de Sigmund Freud. v. 19. Rio de Janeiro: Imago Editora, 1996.

(1924) “O Problema Econômico do Masoquismo”. In: Edição

Standard Brasileira das Obras Psicológicas Completas de Sigmund Freud. v. 19. Rio de Janeiro: Imago Editora, 1996.

(1933[1932]) "Novas Conferências Introdutórias sobre Psicanálise”. In: Edição Standard Brasileira das Obras Psicológicas Completas de Sigmund Freud. v. 22. Rio de Janeiro: Imago Editora, 1996.

GARCIA-ROZA, L. A. (1986) Acaso e Repetição em Psicanálise - uma introdução à teoria das pulsões, $7^{\mathrm{a}}$ ed. Rio de Janeiro: Jorge Zahar Ed. 2003.

O Mal Radical em Freud. Rio de Janeiro: Jorge

Zahar Ed. 1990.

(1995) Introdução à Metapsicologia Freudiana,

vol. 3. Rio de Janeiro: Jorge Zahar Ed. 2002.

GOMES, G. (2001) “Os Três Conceitos Freudianos de Trieb”. In: Psicologia: teoria e pesquisa/UFF. Rio de Janeiro, vol. 17, n. 3, pp. 249-255. 
GREEN, A. Pulsão de Morte, Narcisismo Negativo, Função Desobjetalizante. In: A Pulsão de Morte, pp. 57-68, $1^{\text {a }}$ ed. São Paulo: Editora Escuta, 1988.

HAANS, L. Dicionário Comentado do Alemão de Freud, $1^{\text {a }}$ ed. Rio de Janeiro: Imago, 1996.

A Teoria Pulsional na Clínica de Freud, $1^{\text {a }}$ ed. Rio de Janeiro: Imago, 1999.

JEBER, L. J. Educação pela Autonomia Através da Auto-Regulação: Uma perspectiva reichiana. In: Revista Escritos Sobre a Educação. Ibirité, v. 5, n. 1, pp. 26-32, jan. - jun. 2006.

LAPLANCHE, J. PONTALIS, J. B. (1982). Vocabulário de Psicanálise, $4^{\mathrm{a}}$ ed. São Paulo: Martins Fontes, 2001.

LONGMAN DICTIONARY, Of Contemporary English, (1978). UK, Longman Group, 1994.

MALDONADO, G. Um Estudo Sobre o Conceito Freudiano de Pulsão de

Morte. 2005. 95 p. Dissertação (Mestrado) - Pontifícia Universidade Católica do Rio de Janeiro.

MATTHIESEN, S. Q. Organização Bibliográfica da Obra de Wilhelm Reich, $1^{\mathrm{a}}$ ed. São Paulo: Editora Annablume, 2007.

Sobre as traduções da obra de Wilhelm Reich para o português, in: Psicologia: Teoria e Pesquisa, vol. 26, n. 3, Brasília, jul./set. 2010. MEZAN, R. (2001) A Trama dos Conceitos. São Paulo: ed. Perspectiva, 2008. RAKNES, O. (1970) Wilhelm Reich and Orgonomy: the controversial theory of life energy. Baltimore, Maryland: Penguin Books, 1971.

REGO, R. A. Psicanálise e biologia: uma discussão da pulsão de morte em Freud e Reich. 2005. 288 p. Tese (doutorado) - Instituto de Psicologia da Universidade de São Paulo.

REICH, W. (1922) "Drive and Libido Concepts from Forel to Jung”. In. Early Writings, Volume One. New York: Farrar, Straus and Giroux, 1975. (1923) "Concerning the Energy of Drives". In: Early writings. Volume one. Trad. Philip Schmitz. New York: Farrar, Strauss \& Giroux, 1975(a). pp. 143-157.

- (1925) “The Impulsive Character". In. Early Writings, Volume One. New York: Farrar, Straus and Giroux, 1975. 
(1925) O Caráter Impulsivo: um estudo psicanalítico da patologia do ego. São Paulo: Ed. Martins Fontes, 2009.

(1927) A Função do Orgasmo: Psicopatologia e Sociologia

da Vida Sexual. São Paulo: Global, s.d.

(1927) Die Funktion des Orgasmus: Zur Psychopathologie

und zur Soziologie des Geschlechtslebens, Wien: Internationaler

Psychoanalytischer Verlag, s.d.

(1932) O Caráter Masoquista. In: Análise do Caráter $3^{a}$ ed.

São Paulo: Martins Fontes, 2001.

(1933) Algumas Observações Sobre o Conflito Básico entre

Necessidade e Mundo Interno. In: Análise do Caráter $3^{a}$ ed. São Paulo: Martins Fontes, 2001.

(1942) A Função do Orgasmo: Problemas Econômico-

Sexuais da Energia Biológica. 11 ${ }^{\text {a }}$ ed. São Paulo: Brasiliense, 1975. (1952) Reich Fala de Freud. Lisboa: ed. Moraes, 1979. (1956) The re-emergence of Freud's "Death Instinct" as

“DOR” Energy. In: Orgonomic Medicine, v. II, n. 1, p. 2-11, 1956.

ROUdINESCO, E., PLON, M. Dicionário de Psicanálise. Rio de Janeiro: Ed. Jorge Zahar, 1998.

SILVA, J. R. O. O desenvolvimento da noção de caráter no pensamento de Reich. 2001. 161 p. Dissertação (mestrado) - Instituto de psicologia da Universidade de São Paulo.

SOUZA, P. C. (1998) As Palavras de Freud: o vocabulário freudiano e suas versões. São Paulo: Ed. Companhia das Letras, Kindle Edition, 2009.

STRACHEY, J. (1969a) In: Edição Standard Brasileira das Obras Psicológicas Completas de Sigmund Freud. v.1. p. 31. Rio de Janeiro: Imago Editora, 1996. (1969b) In: Edição Standard Brasileira das Obras Psicológicas Completas de Sigmund Freud. v. 14. p. 117. Rio de Janeiro: Imago Editora, 1996.

TAVARES, P. H. M. B. As Novas Traduções de Freud Feitas Diretamente do Alemão: Estilo e Terminologia. In: TradTerm, v. 19, pp. 109-126, São Paulo, Universidade de São Paulo, novembro/2012. http://tradterm.vitis.uspnet.usp.br 
VOLPI, J. H.; VOLPI, S. M. Psicologia Corporal: um breve histórico. Centro Reichiano, Curitiba, 2003. www.centroreichiano.com.br

WAGNER, C. M. Freud e Reich: Continuidade ou Ruptura. São Paulo: Summus Editorial, 1996.

WINOGRAD, M. “A Pulsão e as Fronteiras da Psicanálise”. In: Trieb (Rio de Janeiro), vol. V, p. 149 - 162. Rio de Janeiro, Pontifícia Universidade Católica do Rio de janeiro, 2006

Freud e a Fábrica da Alma: sobre a relação corpopsiquismo em psicanálise. Curitiba: Ed. Appris, 2013.

ZWICK, R. Sobre a Tradução de Um Termo Empregado por Freud. In: Freud, S. O Mal Estar na Cultura. Tradução de Renato Zwick, pp. 190-191, Porto Alegre: Ed. L\&PM, 2010. 